\title{
LA PEDAGOGÍA CATÓLICA ITALIANA: ENTRE EL POSITIVISMO Y EL NEOIDEALISMO. NOTAS SOBRE SU PRESENCIA EN ESPAÑA (I870-1968)
}

\section{Italian Catholic pedagogy: between positivism and neo-idealism. \\ Notes on his presence in Spain (1870-1968)}

\author{
Conrad Vilanou Torrano \\ Correo-e: cvilanou@ub.edu \\ Isabel Vilafranca Manguán \\ Universidad de Barcelona \\ Correo-e: ivilafranca@ub.edu
}

Recibido: 3 de mayo de 20I8. Envío a revisores: II de junio de 2018 Aceptación final: Io de noviembre de 2020

RESUMEN: En este artículo los autores revisan la evolución de la pedagogía italiana desde la perspectiva de la tradición católica, desde los tiempos del Risorgimento en el siglo xix hasta i968. Con este objetivo, se dibujan las grandes líneas del pensamiento pedagógico italiano sobre el poso de la herencia católica que se sitúa en un término medio entre el positivismo que se desarrolló en el tránsito del siglo XIX al xx y el neoidealismo de Giovanni Gentile que marcó el rumbo de la filosofía transalpina durante las primeras décadas del siglo pasado, con importantes resonancias en la reforma educativa fascista. Después de dibujar este mapa conceptual e intelectual, el artículo fija su atención en tres referentes de la pedagogía católica para España como son la educación salesiana de san Juan Bosco, presente en nuestro país desde fines del siglo xix; la influencia de la neoescolástica que a través de la orientación psicopedagógica de Angelo Gemelli caló en la Universidad Católica del Sagrado Corazón de Milán, fundada en 1920 e inaugurada el año siguiente, y, por último, y después de la caída del fascismo, en el neoespiritualismo que a través de autores como Michele Federico Sciacca puede entenderse como la evolución natural del neoidealismo hacia posiciones más creyentes y confesionales.

Palabras clave: Italia; pensamiento educativo; neoidealismo; Iglesia; educación católica. 
AвsтRACT: In this article, the authors review the evolution of Italian pedagogy from the perspective of the Catholic tradition, from the time of the Risorgimento in the I9th century to I968. With this objective, the main lines of Italian pedagogical thought are drawn on the grounds of Catholic heritage that is situated in the middle ground between the positivism that developed in the transition from the igth to the 2oth century, and the neo-idealism of Giovanni Gentile that set the course for transalpine philosophy during the first decades of the last century, with important resonances in the fascist educational reform. After drawing this conceptual and intellectual map, the article turns its attention to three referents of Catholic pedagogy for Spain such as the Salesian education of san Juan Bosco, present in our country since the end of the igth century: the influence of neo-scholasticism that through the psycho-pedagogical orientation of Angelo Gemelli he entered the Catholic University of the Sacred Heart of Milan, founded in 1920 and inaugurated the following year, and finally, and after the fall of fascism, in neo-spiritualism that through authors like Michele Federico Sciacca can be understood as the natural evolution of neo-idealism towards more believing and confessional positions.

KEY wORDs: Italy: educational thought, neo-idealism, Church, Catholic education

$\mathrm{N}$

O HAY DUDA DE QUE, por razones obvias, el catolicismo constituye un referente en el pensamiento pedagógico italiano contemporáneo. Sin embargo, cuando miramos las cosas con atención, observamos que durante el proceso de unificación italiana -que a grandes rasgos comprende dos fases, la Italia carbonaria (I789-I83I) y la del Risorgimento (I83I-I86I) - se detecta una influencia importante de los vientos secularizadores, que procedían de la Revolución francesa. No en vano Garibaldi, nacido en Niza (Piamonte por aquel entonces), ha sido presentado como el redentor de la patria, siendo considerado un afrancesado que vio en el país galo un ejemplo a seguir e imitar ${ }^{1}$. Por su parte, Fabrizio del Dongo -el joven italiano protagonista de La Cartuja de Parma (I839) de Stendhal- buscó enrolarse en el ejército napoleónico que combatió en la batalla de Waterloo (I8I5).

De manera recíproca, Francia consideró a Italia una especie de hermana menor, situación que se manifestó sobre todo durante la Primera Guerra Mundial cuando contendían en el mismo bando. Basten un par de ejemplos. Cuando en I915 Gaziel (Agustín Calvet) visitó Reims encontró, en medio de la desolación, unas escuelas subterráneas, unas escuelas de guerra para atender a los niños, mixtas y divididas en clases por razón de edad, con nombres sonoros, entre los que destacan Garibaldi y D’Annunzio². Por su parte, L'Illustration, en su número 3897, correspondiente al sábado io de noviembre de I9I7, recordaba en su portada que hacía 58 años las tropas francesas habían sido recibidas entusiásticamente en

Giuseppe Garibaldi. Storia della sua vita narrata al popolo da un ufficiale garibaldino I883, Introducción de Concetta Muscato Daidone, Siracusa, CMdEdizione, 2012.

2 Gaziel: En las líneas de fuego (1915), Barcelona, Casa Editorial Estudio, 1917, p. 299. 
LA PEDAGOGÍA CATÓLICA ITALIANA: ENTRE EL POSITIVISMO

Y EL NEOIDEALISMO. NOTAS SOBRE SU PRESENCIA EN ESPAÑA (I870-I968)

CONRAD VILANOU TORRANO E ISABEL VILAFRANCA MANGUÁN

Génova, el 29 de abril de i859. Ahora, en I917, como entonces -en I859- franceses e italianos luchaban contra los austríacos. De ahí la desazón de muchos cuando Mussolini declaró la guerra a Francia el ıo de junio de i940.

En realidad, la periodización que hemos planteado en torno al proceso de unificación italiana -sobre la que resulta difícil el consenso-corresponde a la realizada por Indro Montanelli, si bien no es aceptada por todo el mundo. Añádase que el inicio del Risorgimento -así como su definición- se mantiene como una cuestión disputada sobre todo después de una visión un tanto idílica y romántica que predominó hasta el fin de la Primera Guerra Mundial y que se hizo crítica a partir de $191^{3}{ }^{3}$. Si simplificamos las cosas, se constatan dos grandes interpretaciones sobre la génesis de este movimiento que para algunos depende de la influencia extranjera $y$, por tanto, del jacobinismo, mientras que otros -como Spaventa- sostienen que constituye una fenomenología estricta y genuinamente italiana, que hunde sus raíces en el Renacimiento, con lo que Italia abre las puertas a la civilización moderna $a^{4}$.

Comúnmente se acepta que este movimiento político e intelectual que acompañó el proceso de la unidad italiana tuvo dos referentes, uno político en el Piamonte y otro religioso en Roma, con el Papado. Esta situación provocó tensiones que fueron puestas de relieve por Gramsci en sus reflexiones históricas:

El Risorgimento es un desarrollo histórico complejo y contradictorio, que resulta integral con todos sus elementos antitéticos, de protagonistas y antagonistas, de sus luchas, de las modificaciones recíprocas que las luchas mismas determinan y también de las funciones de las fuerzas pasivas y latentes como las grandes masas agrícolas, y además, naturalmente, de las funciones eminentes de las relaciones internacionales 5 .

Todo indica que, a pesar de los vientos secularizadores, el mundo italiano mantenía el referente católico aunque, naturalmente, las cosas no eran como antes. Alessando Manzoni -en su conocida novela Los novios, escrita durante la primera mitad del siglo XIX, que llegó a convertirse en una pieza esencial de la cultura del Risorgimento-describe la realidad social del siglo xviI, cuando la presencia de la religión constituía un factor capital y los frailes gozaban del mayor respeto social. Precisamente la literatura de Manzoni fue rescatada por la reforma Gentile, que vio en los autores clásicos italianos un referente para combatir el escepticismo religioso. Estas fueron las palabras que Lombardo-Radice escribió en I924, con relación a los programas de instrucción primaria de la reforma gentiliana: «Y han adoptado un modelo de fe en la obra de Alejandro Manzoni, el más grande

Seguimos aquí la periodización que planteó Indro MonTANELLI en sus obras sobre la historia italiana: La Italia jacobina y carbonaria (I789-183I), Barcelona, Plaza \& Janés, 1973 y La Italia del Risorgimento (1831-186I), Barcelona, Plaza \& Janés, I974.

+ Sciacca, Michele Federico: Estudios sobre filosofía moderna, Barcelona, Editorial Miracle, 1966, p. 28I.

Gramsci, Antonio: El Risorgimento, traducción, edición y notas de Guillermo David, Buenos Aires, Las Cuarenta, 2008, p. 135. 
representante en el campo seglar de la conciencia religiosa contra el escepticismo que fue y es todavía enfermedad nuestra ${ }^{6}$.

Ciertamente la enseñanza religiosa fue un tema a debate en la Italia liberal ya que si la ley Casati (I859) no la excluyó de la escuela, sí procuró limitar el acceso de la Iglesia a la enseñanza. De hecho, la presencia de la religión en la escuela sufrió vaivenes, siendo abolida en ocasiones y restaurada en otras. Incluso en momentos puntuales, antes de la unificación, se aprobaron disposiciones como la ley Urbano Rattazzi (1852), bajo el mandato del conde de Cavour, en el reino de Cerdeña-Piamonte, que reordenaba el mapa de las órdenes religiosas, hasta eliminar más de trescientos conventos, buena parte de ellos dedicados a la vida contemplativa. De esta manera se confirma que la secularización dejó su huella en Italia y así Giovanni Papini recuerda -en el prólogo a su libro sobre san Agustínque seguía las clases en una escuela instalada en un antiguo convento florentino, sirviendo la iglesia de gimnasio ${ }^{7}$.

Claro está que la puesta en marcha de la Acción Católica a partir de I865 supuso un contrapeso al proceso de laicización, con lo que los enfrentamientos estaban servidos. Curiosamente dos liberales como Cavour y Rattazzi fueron los protectores de la obra de Don Bosco, cuando abrió su Oratorio de Turín, para cuyo sostenimiento pasó tantas vicisitudes. Con todo, los debates no cesaron hasta la llegada de Gentile al Ministerio de Instrucción a fines de 1922, cuando todavía se mantenían las viejas formas liberales antes del proceso de fascistización de la educación que se agudizó después del caso Matteotti a partir del 5 de enero de 1925. De acuerdo con su ideario filosófico, Gentile propugnaba la enseñanza religiosa como materia escolar en la escuela primaria, pero no en la secundaria hasta la firma de los pactos de Letrán (1929). Al fin y a la postre, la religión -al igual que el arte- formaba parte de la cultura popular, de la cultura del pueblo que el neoidealismo entendía como una manifestación de la conciencia que daba sentido al espíritu, globalmente considerado. De ahí, pues, que el Evangelio -con la figura emblemática de Cristo- fuese recuperado después de años de tibieza y aparente neutralidad religiosa.

\section{Una mirada al Risorgimento: hacia la conciliación religiosa}

Sabido es que, durante buena parte del Ochocientos, la Iglesia constituía un Estado que abarcaba una extensa geografía en el centro y el septentrión de la península itálica, limitando al sur con el Reino de las Dos Sicilias y al norte con

6 Lombardo-Radice, Giuseppe: La Reforma escolar italiana, traducción y prólogo por María Victoria Jiménez, Madrid, Ediciones de La Lectura, 1927, pp. I37-138.

7 «La escuela era, naturalmente, un antiguo convento expropiado, y su iglesia había sido transformada en sala de gimnasia. Y cuando yo trepaba por las pértigas (¡qué quemazón en las manos!), o esperaba en fila la voz de mando para tomar las paralelas al asalto, divisaba allá arriba, en los elegantes frescos, a un barbudo canoso y una mitra episcopal, que debían pertenecer, así fantaseaba yo, al autor de las Confesiones» (PAPINI, Giovanni: San Agustín, Madrid, Ediciones Fax, 1965, p. 6). 
CONRAD VILANOU TORRANO E ISABEL VILAFRANCA MANGUÁN

el Reino Lombardo-Véneto, bajo la administración austríaca. Ni que decir tiene que la complicada geopolítica italiana se completaba con otros reinos como el de Cerdeña-Piamonte -que desde Turín lideró la unidad italiana- y otros ducados (Toscana, Parma, Módena). Una realidad fragmentada, con variedades dialectales, que contó con destacados líderes patrióticos (Cavour y Garibaldi) y en que la lengua toscana se acabó imponiendo. No en balde, Manzoni -pese a sus tendencias lombardas- presidió la Comisión para la unificación de la lengua (I862), punto capital del Risorgimento desde el momento que Gentile remarcaba en La Riforma dell'educazione (1920) el papel de la lengua como base del concepto de nacionalidad.

Entre los patriotas italianos también hay que destacar a Giuseppe Mazzini, que con su misticismo político representaba la cultura laica o la religión civil, a quien Edmundo de Amicis dedicó unas páginas en su conocido Cuore. De hecho, Mazzini hizo bueno el ideal de «pensiero e azione», convirtiéndose en un referente que adquirió la condición de profeta que, además, no negaba la dimensión religiosa del ser humano. Tanto es así que Francesco de Santis en su biografía sobre Mazzini lo sitúa en la línea espiritualista del siglo xIX, contraria a la irreligiosidad del Iluminismo. «Nel secolo xIx abbiamo Manzoni, Rosmini, Gioberti, Mazzini, Berchet, Rossetti, tutti, se così si potesse dire, pieni di spirito deista» ${ }^{8}$.

En el fondo, Mazzini puede ser considerado el profeta de una religiosidad laica, un antecedente de la posición de Gentile, según este reflejó en Che cosa è il fascismo (1925). En efecto, el filósofo neoidealista vio en Mazzini «il risuscitatore delle energie nazionali», que desde la revista La Giovine Italia (I83I) defendía las ideas de libertad, igualdad, humanidad, independencia y unidad. Tan es así que los historiadores han percibido la presencia de la religión patriótica de Mazzini en la iconografía y simbología del fascismo, cosa que no ha de extrañar si tenemos en cuenta las simpatías de Giovanni Gentile por la figura de Mazzini.

El mazzinismo hizo un notable aporte a la sacralización de la política. Su religión laica tuvo influencia indirecta, especialmente por intermedio de la peculiar interpretación de Giovanni Gentile, en la formación de la teología política fascista. Pero es justo recordar que Mazzini mantenía firme la afirmación del principio de la libertad del ciudadano y de la dignidad individual ${ }^{9}$.

Sin embargo, sería un error identificar el patriotismo italiano con una actitud contraria a la religión católica, tal como se desprende de la confesión autobiográfica de Silvio Pellico, Mis prisiones (1832), en que narra los avatares de este líder - profesor de francés en el Colegio de Huérfanos Militares de Milán- que fue encarcelado por las autoridades austríacas. Pasó por diversas prisiones: Santa Margarita; luego, en los Plomos de Venecia, y, finalmente, en Spielberg, cerca

8 De SAnctis, Francesco: Mazzini, saggio introduttivo, note, biografia, repertorio dei nomi e cura del testo di Vincenzo Gueglio, Genova, Fratelli Frilli editori, 2005, p. I04.

9 Gentile, Emilio: El culto del Littorio. La sacralización de la política en la Italia fascista, Buenos Aires, Siglo XXI, 2007, p. 22. 
de Breno, siendo puesto en libertad en I830. Gracias a su director espiritual, un sacerdote católico, empezó a redactar sus memorias con la intención de mostrar la «inmensa caridad de Dios con los infelices que recurren a su gracia», a la vez que mostraba como «el deísmo y la filosofía son impotentes en comparación con la religión católica» ${ }^{10}$. Queda claro, pues, que Pellico -a pesar de su condición de patriota y carbonario- lanzó un alegato a favor de la religiosidad humana, en la línea de la ortodoxia católica y así renunció a la dedicatoria que Vicenzo Gioberti -después de criticar a los jesuitas- había estampado en la primera edición del Primato morale e civile degli italiani (1843), aparecido en Bruselas.

Silvio Pellico, que había aceptado la dedicatoria del Primato, cuando la obra fue nuevamente editada en el año 1845, precedida por los Prolegomeni y con la misma dedicatoria mandó al Universo (25 de junio de 1845 ) una carta de protesta contra las críticas de Gioberti a la Compañía. Pellico reprochaba al exiliado piamontés el haber creído describir a los Jesuitas de acuerdo «con la verdad», cuando en rigor no había hecho de ellos «más que una odiosa pintura» ${ }^{11}$.

Hay que añadir que Los deberes del hombre. Discurso dirigido a un joven (I834), constituye un tratado cívico-moral escrito por Pellico en 32 capítulos que circuló con gran profusión en España, desde comienzos del siglo xix, tanto en lengua castellana como catalana ${ }^{12}$. Todavía en 194I, en pleno franquismo, aparecía una nueva traducción bajo el título de Los deberes de los hombres, lo cual confirma la longevidad de una obra escrita por un carbonario que no despertó -por razón de su religiosidad- los recelos del nacional-catolicismo español ${ }^{13}$. En sus consejos, Pellico exhorta a honrar la religión, basada en el espíritu evangélico que practica la filantropía o caridad, sin olvidar el amor a la patria. De este modo, la religión y la patria se convierten en dos referentes esenciales que apuntan hacia una fraternidad amorosa universal. Niega, además, que la creencia religiosa sea una característica de gente vulgar y simple, escasamente ilustrada, presentando el cristianismo como la religión más pura, que se hermana históricamente con el progreso de la civilización. Así pues, Pellico -un digno representante del Risorgimento- apuesta no solo por la religiosidad humana, sino también por la fuerza del cristianismo.

Cabalmente, Gioberti proponía una confederación de Estados, cada uno con su príncipe, presidida por el papa, que actuaría como una especie de árbitro supremo, a la vez que afirmaba el papel director de la Italia católica en el concierto continental. Desde una posición moderada, Gioberti -promotor de una reforma católica de signo liberal- ${ }^{14}$ apostó por el neogüelfismo, esto es, un movimiento

1o Pellico, Silvio: Mis prisiones, Madrid, Calpe, I922, p. 256.

"Sciacca, Michele Federico: Estudios sobre filosofía moderna, Barcelona, Luis Miracle, 1964, p. 465.

${ }_{12}$ Pellico, Silvio: Els deures dels homens, Barcelona, Llibreria L’Avenç, I9I5.

${ }_{13}$ Pellico, Silvio: Los deberes de los hombres, nueva traducción del italiano por Manuel de Montoliu con notas de R. Forte, Barcelona, Editorial Resurrección, I94I.

${ }^{14}$ Bonafede, Giulio: «Filosofía y religión en Gioberti», Crisis, n. ${ }^{\circ}$ I (1954), pp. 44I-464. 
CONRAD VILANOU TORRANO E ISABEL VILAFRANCA MANGUÁN

católico favorable a la unidad italiana, sin desdeñar la vocación europeísta, cuyo nombre recuerda la Edad Media cuando se apelaba a la defensa que los güelfos hicieron del poder papal frente a los gibelinos partidarios del emperador ${ }^{15}$. Sus ideas políticas -en especial su enemiga respecto los jesuitas-se mantuvieron en el candelero durante décadas, de modo que si el neogüelfismo pasó muy pronto, sus ataques a los jesuitas -formulados especialmente en el Il Gesuita moderno (I846I847)- dejaron su impronta. «Los jesuitas perdieron su influencia sobre la política de los príncipes italianos y especialmente el Rey saboyano» ${ }^{16}$. Al fin y al cabo, Gioberti retrató en la figura del jesuita moderno aquello que, precisamente, los jesuitas aferrados a posturas tradicionales negaban: una especie de religión civil, liberal y progresista, donde la Iglesia actuara de catalizador de la reforma política y de la civilidad pública. De cualquier modo, sus ideas pedagógicas -tendencia a la autoeducación, fomento del pensamiento creador, aspectos que preludian y anticipan el neoidealismo- llegaron un tanto tardíamente hasta nuestras bibliotecas a través del libro L'educazione nazionale, en una selección de Enzo Bonaventura $(1923)^{17}$.

A la larga, empero, las cosas fueron por otra dirección porque la Iglesia -un tanto a la defensiva después de la revolución de I848 y de la apertura inicial de Pío IX, que fue ensalzada por nuestro Jaime Balmes- mantuvo resistencias al proceso de la unidad italiana, que erosionaba sus intereses políticos. Por lo tanto, no extraña que ante el acoso de las tropas garibaldinas el Concilio Vaticano I fuese clausurado un tanto precipitadamente en I870. Efectivamente, con la caída de Roma -el 2 de octubre de i870- se culminaba la unidad italiana, después de las guerras del Risorgimento y de un largo proceso de unificación que había dado un paso crucial con la proclamación del reino de Italia el i7 de marzo de i86ı. Sea como fuere, recordemos la opinión de Indro Montanelli cuando señala que Italia no se había hecho a sí misma, como pretende en ocasiones la historiografía oficial, sino que «lo había hecho la monarquía saboyana guiada por el genio de uno de sus ministros, Cavour, que quería extender el reino de Cerdeña hasta Lombardía y el Véneto» ${ }^{18}$.

Mejor o peor, Antonio Fogazzaro en su descripción de aquel Pequeño mundo antiguo (aparecido el año I895 y en que dibuja la vida en los años anteriores al desencadenamiento del proceso de la unidad italiana de i860) ya se hizo eco de las tensiones entre la política y la religión, cuando contrapuso en el matrimonio protagonista de la historia -formado por Francisco y Luisa- la colisión de dos universos. Mientras Francisco -el aristócrata desclasado que apuesta a favor de la unidad italiana y en contra de los intereses austríacos- se muestra profundamente religioso, su esposa (Luisa) aparece como distante de la práctica religiosa, cercana

is Gramsci, Antonio: El Risorgimento, traducción, edición y notas de Guillermo David, Buenos Aires, Las Cuarenta, 2008, p. 49 .

${ }_{16}$ Sciacca, Michele Federico: Estudios sobre filosofía moderna, op. cit., pp. 479-48o.

17 Gioberti, Vincenzo: L'educazione nazionale, pagine pedagogiche scelte e ordinate con introduzione e note di Enzo Bonaventura, Firenze, G. C. Sansoni, editore, 1923.

18 Montanelli, Indro: Memorias de un periodista, Barcelona, RBA, 2003, p. 99. 
a una religiosidad natural, un tanto incrédula respecto la fe de sus antepasados, aquellos que entendían «la religión como un conjunto de creencias, de culto y de preceptos, inspirado y dominado por el amor de Dios» ${ }^{19}$. De suyo, Luisa daba las primeras lecciones de lectura a su hija María -muerta prematuramente en un accidente- según el método de Lambruschini, que, junto a Rosmini, puede ser considerado uno de los representantes pedagógicos del catolicismo liberal que tanto influyó en el Risorgimento y que el fascismo intentó recuperar ${ }^{20}$. Sin embargo, el protagonista -Francisco cuando se instala en Turín hacia 1855- no soporta el estudio de la metafísica tomista que había dado sentido a la filosofía perenne, sobre la base aristotélica, y que sería rehabilitada por la neoescolástica, primero en Lovaina con el cardenal Mercier y, más tarde, en la Universidad Católica de Milán, inaugurada el año I921, pocos meses antes de producirse la marcha sobre Roma.

A decir verdad, el Imperio austríaco -la dinastía de los Habsburgo, personificados en «Su Majestad Imperial y Real Austríaca»- había salido en más de una ocasión en defensa de los intereses del Papado. He aquí la descripción de la atmósfera social, según dibuja un católico modernista como Fogazzaro. «Antiguamente aquel pequeño mundo estaba más separado del mundo grande de lo que está hoy y, por consiguiente, era un mundo de silencio y de paz donde los funcionarios del Estado y de la Iglesia, acompañados de algunos súbditos fieles que seguían su ejemplo venerable, consagraban muchas horas del día a una edificante contemplación $»^{21}$. Así, en las casas nobiliarias y burguesas se rezaba diariamente el rosario, abundando los confesores y directores espirituales -recordamos al jesuita Perrone de El Gatopardo- que procuraban por la salvación de las almas de unos pecadores que a menudo vivían la religión a un nivel formal y externo, con la intención de apaciguar su mala conciencia de rentistas y terratenientes, observando además las viejas costumbres sociales, en que la caridad -como privilegio de las clases acomodadas- era moneda corriente. En su narración autobiográfica sobre los lugares de su infancia, G. Tomasi de Lampedusa, nacido en I896, apunta que antes de aprender a leer a los ocho años, le leían alternativamente, y de

19 Fogazzaro, Antonio: Pequeño mundo antiguo, Barcelona, Bruguera, 1986, p. 276.

${ }_{20}$ Antes que Mario Casotti presentase La pedagogia del Lambruschini (Milano, 1929) y $R$. Lambruschini e la pedagogia italiana (Brescia, 1943), el fascismo remarcó la importancia de la tradición pedagógica italiana, a fin de eliminar cualquier intromisión extranjerizante. Lombardo-Radice afirmaba en 1924 que en los programas de la escuela primaria «se han incluido grandes escritorees italianos, casi olvidados hasta hace pocos años, como un Capponi, un Lambruschini» (LombardoRadice, Giuseppe: La Reforma escolar italiana, op. cit., p. in6). La pedagogía de Gino Capponi (1792-1876) tuvo cierta resonancia en España, tal como pone de manifiesto el comentario de Mario SANCIPRIANO: «Angiolo Gambaro y la crítica pedagógica de Gino Capponi», Crisis, n. ${ }^{\circ}$ I2 (octubrediciembre 1956), pp. 587-597. Hay que añadir que el profesor Gambaro rescató la aportación de ambos pedagogos -Lambruschini y Capponi- con diversas monografías y estudios. Luigi VolPICELLI abordó, con todo lujo de detalles bibliográficos, «L'insegnamento del Lambruschini», Cultura e Scuola, n. ${ }^{\circ} 47$ (1973), pp. I24-I3r. Como es lógico, los manuales italianos de historia de la pedagogía que proliferaron después de la Segunda Guerra y que se tradujeron al español (Abbagnano y Visalberghi, Morando, Sciacca, etc.) dedicaban diversos capítulos al espiritualismo del Risorgimento, a la pedagogía del catolicismo liberal italiano y al neoidealismo, entre otros temas.

${ }_{21}$ Fogazzaro, Antonio: Pequeño mundo antiguo, op. cit., p. I3I. 
LA PEDAGOGÍA CATÓLICA ITALIANA: ENTRE EL POSITIVISMO

Y EL NEOIDEALISMO. NOTAS SOBRE SU PRESENCIA EN ESPAÑA (I870-I968)

CONRAD VILANOU TORRANO E ISABEL VILAFRANCA MANGUÁN

manera vicaria, la Historia Sagrada, una especie de Resumen de la Biblia y del Evangelio los martes, jueves y sábados, y los lunes, miércoles y viernes, la mitología clásica, con lo cual se garantizaba el conocimiento del cristianismo y del humanismo pagano 22 .

Por lo general, los jesuitas -que como hemos visto recibieron el embate de Gioberti- actuaban de directores espirituales no escondiendo su desprecio por las ideas liberales que alentaban el proceso de unidad italiana. Croce en sus Aportaciones a la crítica de mí mismo -una especie de relato de formación- recuerda como su madre -que murió trágicamente en un terremoto- a sugerencia de un jesuita le hizo leer las novelas del también jesuita Antonio Bresciani, que lo acercaron a «los pintorescos zuavos pontificios»-esto es, las tropas fieles al Papado que llegaron a frenar a las garibaldinas- a la vez que fomentaban la «aversión por los grises piamonteses». En otras palabras: los directores espirituales pretendían alejar a la juventud del proceso del Risorgimento, siendo tildados los líderes de la unidad italiana de parlanchines liberales y patriotas oportunistas ${ }^{23}$. Además de favorecer este control ideológico, la religiosidad servía para matar el tedio de aquellas familias adineradas que vivían un proceso de deterioro un tanto decadente, y así Lampedusa recogió que la media hora entre el rosario y la cena constituía uno de los momentos más irritantes de la jornada en la vida del príncipe aristócrata ${ }^{24}$.

Lógicamente, España fue receptiva a las tensiones que se produjeron en el seno del Risorgimento, de manera que el catolicismo liberal italiano -con Antonio Rosmini (I797-I855) a la cabeza-dejó su huella entre nosotros. Por supuesto, las cosas venían del período ilustrado, lo cual explica la circulación en España de las obras del abate Antonio Martini, que llegó a ser arzobispo de Florencia. Entre los méritos de este prelado, destaca el haber traducido la Biblia a la lengua toscana, «cuya versión, dedicada al difunto Víctor Amadeo rey de Cerdeña, consta de 23 tomos impresos en Turín, y se halla particularmente elogiada y recomendada por nuestro SS.mo Padre Pío VI en su Breve de I7 de Marzo de I778». Así se explicaba el traductor del Espíritu de la Biblia y moral Universal sacada del Antiguo y Nuevo Testamento, escrita en toscano por Martini, obra

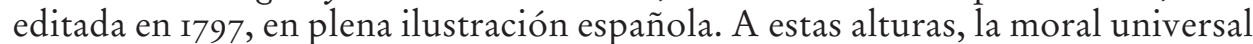
se inspiraba todavía en las Sagradas Escrituras poniéndose al servicio -a través de colecciones de máximas, consejos y preceptos- de la «prosperidad y buen orden, no solo de la república civil y cristiana en que vivimos, sino de cualquiera otra república o gobierno que los filósofos más especulativos y profundos del orbe quieran discurrir» (pp. VII-IX). Para el abate Martini, la religión era "útil y consoladora en los infortunios», "una religión que refrenando todos los movimientos del corazón, los dirige hacia el amor de Dios, origen de todo bien, y la única que nos hace felices, en suma, que todos los grandes hombres del

22 Di Lampedusa, G. Tomasi: «Els llocs de la meva infància», en Tots els contes, Barcelona, Editorial Empúries, 1988, pp. 89-150.

23 Croce, Benedetto: Aportaciones a la crítica de mí mismo, Valencia, Pre-textos, 2000, p. 18.

24 Di Lampedusa, G. Tomasi: El Gatopardo, Barcelona-México, Editorial Noguer, 1959, p. 2I. 
cristianismo, desde los primeros siglos hasta el presente, han profesado inviolablemente, haciendo alarde de esta profesión» (p. XIV).

$\mathrm{Al}$ conjunto de las anteriores consideraciones, hay que añadir la influencia de Rosmini en el pensamiento español que se produce en dos momentos. De un lado, durante el siglo xix, pero también en el siglo xx, con ocasión del primer centenario de su fallecimiento. Además de una notable producción interna española en aquel momento -situados en 1955- también llegaron a nuestras bibliotecas las versiones de originales italianos ${ }^{25}$. Con motivo de ese centenario rosminiano, Adolfo Muñoz Alonso glosó la presencia del filósofo italiano en el pensamiento español, situando a Balmes, Zeferino González y Menéndez Pelayo entre sus epígonos hispanos ${ }^{26}$. Con anterioridad a estas consideraciones, Enrique Herrera Oria se había referido -en las vísperas de la Segunda República- al desarrollo del catolicismo en ambos países durante el siglo XIX, comparando los nombres italianos de Contardo Ferrini, Giuseppe Toniolo y Nicolò Rezzara con nuestros Balmes y Menéndez Pelayo. De este modo, y frente a la influencia krausista importada por Julián Sanz del Río, emerge una tradición conservadora-católica, que se extiende de Balmes a Menéndez Pelayo, jalonada por políticos como Cánovas y Maura. Una influencia que seguirá con Luigi Sturzo y el Partido Popular italiano que dejó sentir sus huellas sobre políticos como Ángel Ossorio y Gallardo y José María Gil Robles.

A los ojos de Adolfo Muñoz-Alonso -siempre próximo al espiritualismo transalpino- Rosmini intenta buscar una conciliación en «la filosofía, teniendo en cuenta la presencia del cristianismo católico, sin renegar de la evolución del pensamiento, aceptando los errores como desviación en el recorrido, no como detención» ${ }^{27}$. Por su parte, el profesor José Antonio Jordán abordó la cuestión de la teoría espiritualista de la educación de Rosmini y el Risorgimento italiano, perfilando las características de su «teoría espiritualista de la educación» que sirvió de caldo de cultivo no solo para defender los postulados de la tradición cristiana, sino también para oponerse a la difusión de los vientos positivistas y cientifi$\operatorname{cistas}^{28}$. En el fondo, las raíces de este espiritualismo se hunden en el siglo XviII, aflorando sus manifestaciones durante el Risorgimento ${ }^{29}$. Ya Sciacca remarcó la

${ }_{25}$ Sciacca, Michele Federico: El pensamiento filosófico de Antonio Rosmini, Barcelona, Miracle, 1954; Sciacca, Michele Federico: «Los principios de la metafísica rosminiana», en Sísifo sube al Calvario, Barcelona, Editorial Miracle, I964, pp. I3I-I64.

${ }_{26}$ El salesiano italiano Salvatore de BonIs presentó una tesis sobre Menéndez y Pelayo en el Pontificio Ateneo Salesiano que se tradujo con el título de Posición filosófica de Menéndez y Pelayo, con prólogo de Juan Roig y Gironella (Barcelona, Editorial Casulleras, 1954). Para este autor, Menéndez y Pelayo se sitúa en la estela de la tradición filosófica de la Universidad de Cervera que cristalizó en la escuela filosófica catalana (Ramón Martí d'Eixalá, Francisco Llorens Barba).

${ }_{27}$ Muñoz-Alonso, Adolfo: «Antonio Rosmini y la filosofía española», Crisis, n. ${ }^{\circ} 2$ (1955), pp. I43-I48 (la cita corresponde a la p. I45).

28 Jordán Sierra, José Antonio: «Teoría espiritualista de la educación en Rosmini y el Risorgimento italiano", Revista Española de Pedagogía, XLI, n. ${ }^{\circ}$ I59 (enero-marzo 1983), pp. II9-I29.

${ }^{29}$ Petrocchi, Massimo: «La spiritualità nel Settecento italiano», Cultura e Scuola, n. ${ }^{\circ} 27$ (1968), pp. 68-83 y n. ${ }^{\circ} 28$, I968, pp. 88-98. 
CONRAD VILANOU TORRANO E ISABEL VILAFRANCA MANGUÁN

dimensión espiritualista de este movimiento patriótico-cultural, al señalar que «el pensamiento italiano de la primera mitad del siglo XIX es un Espiritualismo que, en su esencia, no es kantiano y es anti-idealista en relación con el idealismo trascendental de Fichte a Hegel» ${ }^{30}$.

Bien mirado, Rosmini establece un puente entre el espiritualismo y el personalismo, principios que darán sentido a buena parte de la pedagogía italiana de significación católica, después de haber pasado el sarampión del positivismo (Ardigò), que puede ser visto como una respuesta al idealismo de corte hegeliano. Frente a ello, el neoidealismo (Gentile) establece, a su vez, una alternativa neohegeliana al positivismo e, igualmente, al materialismo marxista. Sin adelantar acontecimientos, bien podemos decir que esta «filosofía dello Spirito» -teñida con connotaciones cristianas y depurada de sus connotaciones fascistas- llegó también a España a través del pensamiento de Papini y Sciacca, cuyas obras encontraron aquí -en la península Ibérica- una buena acogida, sobre todo durante los años del franquismo, a mediados del siglo pasado. Pero no perdamos el hilo y volvamos a los orígenes de esta historia.

Ciertamente, Fogazzaro - del que se ha dicho que constituye un puente entre Manzoni y Lampedusa- supo captar aquel ambiente de una Italia en mantillas, forjada en medio de un mundo romántico en que, frente a la religión católica, se alzaba una realidad un tanto heterodoxa, que abarcaba desde el positivismo a las prácticas espiritistas, sin olvidar las corrientes panteístas, masónicas y carbonarias en un ambiente proclive al republicanismo. No en balde, José Carducci -premio Nobel en 1906-, cuyas rimas y odas bárbaras tradujo Hermenegildo Giner de los Ríos, fue un espíritu eminentemente republicano y progresista. Además, las ideas pedagógicas de Carducci merecieron la atención del Boletín de la Institución Libre de Enseñanza (I92I).

De hecho, Hermenegildo Giner -hermano de don Francisco- estableció un puente con la obra de Edmundo de Amicis, autor del famoso Cuore (I886) que sirvió para dar unidad a la Italia reconfigurada bajo la monarquía saboyana que se había enfrentado al $\mathrm{Papa}^{31}$. El libro -donde las alusiones religiosas son escasas, si bien acepta la existencia de la «otra vida» y reconoce la presencia de clases de religión- fue incluido en el Índice, «lo que motivó que en España no haya sido leído -según comenta Fernando Díaz-Plaja- por los jóvenes nacidos después de la Guerra, mientras era popularísimo entre los que leíamos antes de iniciarse» ${ }^{32}$. Por su parte, Josep Pla -con su ironía característica- no dudó en tildar de sentimental esta obra pedagógica, hasta el extremo de sugerir que su lectura ha generado un verdadero diluvio de lágrimas ${ }^{33}$.

3o Sciacca, Michele Federico: Estudios sobre filosofía moderna, op. cit., p. 457.

31 CANes Garrido, Francisco: «La influencia del libro Corazón del italiano Edmundo de Amicis en la educación española», en Hernández DíAz, José María: Influencias italianas en la educación española e iberoamericana, Salamanca, FahrenHouse Ediciones, 20I4, pp. 35-5I.

32 Díaz-Plaja, Fernando: El italiano y los siete pecados capitales, Madrid, Alianza, 1970, 2. ${ }^{\text {ed., }}$ p. 44 .

33 PLA, Josep: Cartes d'Itàlia, Barcelona, Destino, 1983, p. 54. 
Como no podía ser de otra manera, la España liberal -la que derivaba de la filiación krauso-institucionista- también bebía de las fuentes liberales italianas, fenomenología que se confirma con la presencia de diversos autores transalpinos -Mosso, Gentile, Lombardo-Radice, Ugo Spirito, Credaro, etc.- en las páginas del Boletín ${ }^{34}$. Y aunque no son muchas las referencias pedagógicas sobre Italia, «encontramos algunos artículos que dan a conocer la situación real de las novedades, las tendencias pedagógicas legislativas, metodológicas... que se estaban proponiendo en ese país» ${ }^{35}$. Con el paso del tiempo, en pleno franquismo, el espiritualismo italiano -probablemente un fruto tardío del neoidealismo, y que acentuó sus raíces agustinianas- fue presentado como una alternativa a la filosofía del krausismo, tal como reflejó Adolfo Muñoz Alonso en el «Prólogo para españoles» de la Filosofía, boy de Sciacca ${ }^{36}$.

Conocido es que los manuales escolares italianos tuvieron mucho éxito en España, desde el clásico Bertoldo, con sus descendientes Bertoldino y Cacaseno, astucias que gozaron de gran predicamento ${ }^{37}$. Tampoco podemos dejar al margen el famoso Juanito de Parravicini ${ }^{38}$. También hay que recordar las obras de César Cantú, en especial sus Cuentos de mi maestro, versión española de Il buon fanciullo: racconti d'un maestro elementare ${ }^{39}$. Cabe citar, igualmente, los diversos libros de El amigo de Juan Pazzi, método de lectura para la infancia, que entre otros aspectos divulgaba la geografía italiana. Entretanto la literatura histórica, dedicada a los adolescentes, circulaba por nuestras latitudes. Así en 1930 aparecía una segunda edición de Espartaco (I882) de Rafael Giovagnoli, un patriota italiano que

34 «Italia y España», Boletín de la Institución Libre de Enseñanza, viI (I883), pp. 79-80.

35 Montero Pedrera, Ana María y Real Apolo, Carmelo: «Teoría y práctica de la pedagogía italiana en España: su Introducción a través del BILE (1877-1936)», en Hernández Díaz, José María: Influencias italianas en la educación española e iberoamericana, Salamanca, FahrenHouse Ediciones, 20I4, pp. 97-IIs [la cita corresponde a la p. IIo].

${ }_{36}$ "La filosofía española de hoy se ha olvidado sabiamente de la corriente dominante en el pasado siglo. Nos referimos al krausismo español. No han sido sólo razones filosóficas las que han acelerado la difuminación de los krausistas, sino también políticas y literarias. Si para mantener un pensamiento filosófico se necesita martirizar hasta lo imposible al idioma, es preferible enderezar el pensamiento por otros caminos. Por lo demás, las razones extrafilosóficas que han agostado el florecimiento krausista no suponen una alteración de procedimientos en la dialéctica entablada, sino un recurso en la misma línea forzada por el krausismo» (Sciacca, Michele Federico: «Prólogo para españoles", en Filosofía, hoy. De los orígenes románticos de la filosofía contemporánea hasta los problemas actuales, Barcelona, Luis Miracle, 1956, p. 4).

37 Bertoldo, Bertoldino y Cacaseno, o sean las astucias utilísimas de Bertoldo y la ridícula simpleza de Bertoldino con la novela de Cacaseno, tales como fueron escritas en legua toscana, Madrid, Editorial Saturnino Calleja, nueva edición, sin año. Por su parte, José Baeza hizo en el siglo xx varias adaptaciones publicadas por la casa Araluce.

${ }_{38}$ Esteruelas Teixidó, Albert: «El Juanito de Luigi Alessandro Parravicini», en Arte y oficio de enseñar: dos siglos de perspectiva histórica, xvi Coloquio Nacional de Historia de la Educación, El Burgo de Osma, Soria, II-I3 de julio de 20II, vol. 2, pp. 357-365.

39 Cantú, César: Cuentos de mi maestro, traducidos de la décima cuarta edición de Milán por Joaquín Rubió, Valladolid, Impr. de D.J.M. Lezcano y Roldán, 1856. 
CONRAD VILANOU TORRANO E ISABEL VILAFRANCA MANGUÁN

colocaba la Roma antigua como centro del mundo ${ }^{40}$. Acerca de esto, conviene mencionar el éxito que Roma tenía como protagonista de una literatura recreativa y formativa que se ponía al alcance de los niños, según testimonian obras como El nacimiento de Roma, que forma parte de la serie Historias de la historia del mundo de la escritora italiana Laura Orvieto, especializada en literatura infantil y juvenil, cuya primera edición sacaba a la luz la editorial Araluce en i930.

Está claro que ello sucedía cuando el patriotismo -precedente de otros términos como republicanismo, liberalismo, socialismo, nacionalismo, fascismo, imperialismo- se convertía en uno de los referentes de la cultura política escolar del siglo XIx, en el contexto de una joven Italia que acababa de conseguir su independencia y unidad después de duras luchas intestinas. Por todo cuanto venimos diciendo, la unidad italiana desarrolló el concepto de nacionalidad o, mejor aún, la conciencia de nacionalidad, que fue teorizada -entre otros- por Pasquale Stanislao Mancini, que fue ministro de Instrucción Pública en el gabinete Rattazzi (I862) y profesor de derecho en la Universidad turinesa. Después de zafarse del yugo español y austríaco, Mancini en la lección de apertura del Curso de Derecho Internacional y Marítimo, pronunciada en la Universidad de Turín, el 22 de enero de I85I, reflejaba su idea de nacionalidad sobre la base de «una sociedad natural de hombres conformados en comunidad de vida y de conciencia social por la unidad de territorio, de origen, de costumbres y de lengua» ${ }^{41}$.

A tenor de lo expuesto, la lengua y la enseñanza -que al parecer funcionaba mejor en las zonas dependientes del Imperio austro-húngaro- se convertían en pilares de la nueva nación italiana que caminaba hacia su independencia, esto es, a su mayoría de edad. Aunque Mancini tenía a la vista el ejemplo del derecho, no está de más reproducir el siguiente fragmento del discurso que pronunció en I85I y que acabamos de citar:

La enseñanza debe comprender las necesidades de la época y las tendencias de la generación viviente, si quiere ser algo más que un catecismo de áridas abstracciones, de escolásticas sutilezas, de vacías fórmulas sin vida y aplicación práctica que dejen fríos e impasibles a los oyentes y no enciendan en su ánimo ese calor de virtuoso afecto, único que puede fecundar los gérmenes de la doctrina ${ }^{42}$.

Con estos antecedentes, adquieren toda su relevancia las siguientes palabras de Dante Morando, referidas al modelo escolar de la Italia liberal:

El ideal nacional se identificaba con el ideal humano de la redención espiritual del pueblo, y el ideal de la elevación general del hombre. En efecto, en las escuelas se enseñaba sobre todo lengua italiana, la historia patria y sus costumbres y usos,

40 Giovagnoli, Rafael: Espartaco, novela histórica del siglo viI de la era romana, traducción directa del italiano revisada y corregida por el prologuista Vicente Clavel, Barcelona, Editorial Cervantes, 1930 ( $2 .^{a}$ ed.).

${ }^{41}$ Mancini, Pasquale Stanislao: Sobre la Nacionalidad, edición de Antonio E. Pérez Luño, traducción de Manuel Carrera Díaz, Madrid, Tecnos, 1985, p. 37.

${ }^{42}$ Ibidem, p. 6. 
las tradiciones de su gente, pero más que nada se enseñaba a adquirir, a través de las distintas disciplinas más útiles, una humana y sabia autonomía moral, destinada sucesivamente a completarse con la aspiración a la autonomía nacional ${ }^{43}$.

Desde luego, se trataba de una visión ideológica del proceso que, a través del Risorgimento, precipitó la unidad italiana y cuyos ecos llegaron a España a través de la literatura de César Cantú ${ }^{44}$. En aquel contexto, todo parecía indicar que los sacerdotes -sobre todo después de 1848 y especialmente a partir de I860- serían los grandes sacrificados del proceso de la unidad italiana, liderado por la dinastía saboyana que en España era presentada como una alternativa a los Borbones asentados tradicionalmente en el sur de Italia. No en balde, la fugaz monarquía en España de Amadeo de Saboya entre el I6 de noviembre de 1870 y el in de febrero de 1873 -poco más de dos años, en medio de las tensiones del sexenio revolucionario (I868-1874) y que mereció una extensa crónica de Edmundo de Amicis, después de su viaje a España (1872) como corresponsal de prensa- ${ }^{45}$ así lo da entender. Pues bien, Pi y Margall nos dejó una descripción de aquel breve reinado de Amadeo de Saboya, el duque de Aosta, iniciado con mal pie, al morir asesinado su mejor valedor -el general Prim, el 30 de diciembre de i870- días antes de la entrada del nuevo monarca en Madrid. Aun contando con simpatías, fue elegido por I9I votos a favor y I20 en contra. «No le querían ni los republicanos ni los carlistas, que eran los dos grandes partidos de España, ni los antiguos conservadores, que estaban por D. Alfonso ${ }^{46}$. Ahora bien, y al margen de los apoyos un tanto precarios, y siempre según Pi y Margall, «no era Amadeo hombre de gran temple» ${ }^{47}$. Dicho esto, Pi y Margall concluye: «Nada hizo; pero nada le dejaron hacer sus mismos hombres $»^{48}$.

La casa de los Saboya fue una dinastía militar, con una inequívoca devoción religiosa, aunque se dieron monarcas -como Víctor Manuel III, al decir de algunos- que fueron un tanto anticlericales. «Sin embargo, a él le tocó sancionar la conciliación del Estado y de la dinastía con la Santa Sede; pero al parecer mantuvo hasta lo último, mientras se llevaban a cabo las negociaciones, sus desconfianzas

43 Morando, Dante: Pedagogía. Historia crítica del problema educativo, Barcelona, Editorial Luis Miracle, 1972 (5. $\left.{ }^{\mathrm{a}} \mathrm{ed}.\right)$, p. 323. En la novela de Giorgo Bassani El jardín de los Finzi-Contini, ambientada en la vida de la comunidad hebrea establecida en Ferrara, con anterioridad a las leyes raciales de 1938, escribe: «Enviar a los hijos a las escuelas públicas estaba considerado en general patriótico; no hacerlo, derrotista y, por tanto, para todos aquellos que lo hacían ofensivo en cierto modo» (Barcelona, Planeta, 1999, p. 27).

${ }^{44}$ Pí IX y Víctor Manuel o la lucha entre el poder temporal y la unidad italiana llevará por apéndice la importante obra Los heréticos de Italia, Madrid, Elizalde, I868.

${ }_{45}$ De Amicis, Edmundo: España: viaje durante el reinado de Don Amadeo I de Saboya, edición de Susana Urraca y José Javier Fuente del Pilar, Madrid, Miraguano, 2002.

${ }_{46}$ Pi y Margall, Francisco: Trabajos sueltos. Amadeo de Saboya. Juan de Mariana. D. Juan Tenorio, Barcelona, López, editor, Librería Española, sin año, pp. 9-Io.

${ }^{47}$ Ibidem, p. II.

${ }^{8}$ Ibidem, p. 83 . 
CONRAD VILANOU TORRANO E ISABEL VILAFRANCA MANGUÁN

para con la Iglesia» ${ }^{49}$. De hecho, el fascismo -que en sus orígenes poco tenía de católico- se acercó a la Iglesia de manera paulatina, a fin de afianzar y consolidar el régimen que desde el 3 de enero de 1925 constituía una dictadura que había abolido cualquier atisbo de liberalidad después del caso Matteotti ${ }^{50}$. Digamos de paso que Mussolini -que frecuentó el colegio salesiano de Faenza, a pesar del fuerte anticlericalismo paterno, que así pensaba dominarlo- se casó civilmente con Rachele en 1915. Más tarde, se vio obligado a normalizar su situación, celebrando su matrimonio católico el 29 de diciembre de I925, poco después de haber bautizado y confirmado a sus hijos ${ }^{51}$.

En efecto, el II de febrero de 1929, después de tres años de negociaciones secretas, se firmaban en el Palacio Apostólico de Letrán los Pactos que ponían fin a las rencillas (la tan traída «questione romana») de más de medio siglo entre la Iglesia y el Estado italiano -capitaneado por los fascistas- que liquidaba la vieja cuestión romana, con la aceptación del Estado del Vaticano, que recibió importantes compensaciones económicas. También en aquel año de 1929 se beatificaba a san Juan Bosco, canonizado poco después (1934). Tampoco hay que pasar por alto que el último día del año de 1929 se publicó la encíclica Divini Illius Magistri, sobre la educación cristiana de la juventud en que se remarcaba el papel de la Iglesia, como madre educadora, junto a la familia, quedando el poder civil -el Estado- en un papel subsidiario, «favoreciendo y ayudando a la iniciativa y acción de la Iglesia y de las familias, cuya grande eficacia demuestran la historia y la experiencia».

Con todo esto, Mussolini se convertía en un «hombre providencial» para la Iglesia, recibiendo su soporte político y social ${ }^{52}$. Por su parte, esta se garantizaba el derecho a la enseñanza, lo cual debió incomodar a los fascistas que -como Gentile- defendían la superioridad del Estado respecto la Iglesia. Al comentar el Concordato, y la presencia de la religión en la escuela, Gramsci constataba que -contrariamente a las tesis idealistas esgrimidas por la reforma Gentile- la enseñanza religiosa se extendía a las escuelas medias, aunque con carácter no obligatorio. «Esta extensión -escribía Gramsci, recogiendo comentarios del momento- ha venido a contrariar las miras del idealismo que pretendía excluir la religión de las escuelas medias y dejar dominar solo a la filosofía, destinada a superar y absorber en sí a la religión aprendida en las escuelas elementales» ${ }^{53}$.

Ni que decir tiene que la firma de los Pactos de Letrán (I929) supuso un punto de inflexión en el protagonismo público de Gentile, que vio cómo se torcía su

49 Bartoli, Domenico: Víctor Manuel III, Barcelona, Hispano Americana de Ediciones, 1946, p. 84 .

so «Quan el feixisme italià, a imitació de la Revolució Francesa, inventà una nova cronologia, fent-la arrencar del mes d'octubre de I922, cometé una notòria inexactitud, si amb la nova cronologia vol comptar, no els anys de govern de Mussolini, sinó els anys de vida de la revolució feixista. El feixisme integral, no comença en octubre de 1922, sinó en gener de 1925» (СамвÓ, Francesc: Les Dictadures, Barcelona, Llibreria Catalònia, 1929, 2. ${ }^{a}$ ed., p. 108).

${ }_{51}$ Mussolini, Rachele: Mi vida con Benito, Madrid, Editorial Perseo, sin año, p. 86; MussoliNI, Rachele: Benito, mi hombre, Barcelona, Luis de Caralt, I959, pp. 8I-83.

52 Biondi, Dino: El tinglado del Duce, Barcelona, Editorial Planeta, 1975, p. 215.

53 Gramsci, Antonio: Pasado y presente, Buenos Aires, Granica, 1974, pp. I54-I55. 
filosofía de la educación, siempre recelosa de la religión, que debía quedar supeditada a la filosofía. Si Bobbio insinúa que a partir de entonces, en la década de los treinta, Gentile fue desplazado hasta posiciones periféricas, Gramsci dio la siguiente interpretación de lo sucedido en sus Cuadernos desde la cárcel, correspondientes a los años 1932-1935:

Gentile, menos hipócrita y más consecuentemente, ha vuelto a introducir la enseñanza [de la religión] en las escuelas elementales (y la cosa ha ido más allá de lo que quería el mismo Gentile: se ha extendido la enseñanza religiosa también en las escuelas medias) y ha justificado su acto con la concepción hegeliana de la religión como filosofía de la infancia de la Humanidad, concepción que se ha convertido en un puro sofisma al aplicarla a los tiempos actuales, y en un modo de prestar servicio al clericalismo $0^{54}$.

Pero el mismo Gramsci -siempre interesado por las cuestiones pedagógicasse refirió en repetidas ocasiones a estos acuerdos que suponían el reconocimiento del fascismo - una irregularidad democrática, sancionada por la monarquía- por parte de la Iglesia. En sus apuntes dispersos sobre «La reforma Gentile y la religión en las escuelas» daba noticia del artículo «L'ignoto e la religione naturale secondo il senatore Gentile», publicado por La Civiltà Cattolica el 6 de diciembre de 1929. Su Resumen define muy bien cuál era la posición de la Iglesia católica respecto a la filosofía gentiliana, un mal menor vista la marcha de los acontecimientos: «Se examina la concepción de Gentile sobre religión, pero naturalmente están agradecidos por haber introducido la enseñanza de la religión en la escuela» ${ }^{55}$.

\section{Un telón de fondo: el debate positivismo-idealismo}

De alguna manera, el trasfondo social de la unidad italiana comportó un cierto ascenso de la burguesía y, por ende, de una de sus filosofías más genuinas: el positivismo, que reivindicaba un progreso con orden, es decir, con armonía y paz social. Ya Corpus Barga en 1920 dejaba constancia en sus trabajos periodísticos sobre Croce -el filósofo de la tercera Italia, que bajo el influjo del positivismo defendió un historicismo empírico- la influencia de Vico (autor de la Scienza nuova (1725), que pretendió estudiar «a la luz de la providencia divina» la «naturaleza común de los pueblos $»^{56}$ sobre la tradición positivista, a la vez que trazaba una línea de demarcación bien nítida: Vico se convirtió en un referente para los positivistas, mientras que Hegel desempeñaba el mismo papel para los idealistas ${ }^{57}$.

54 Gramsci, Antonio: Antología, selección, traducción y notas de M. Sacristán, México, Siglo XXI, I978, $4{ }^{\text {a }}$ ed., pp. 433-434.

" Gramsci, Antonio: Pasado y presente, op. cit., p. I69.

56 Peters, Richard: La estructura de la historia universal en Juan Bautista Vico, Madrid, Revista de Occidente, I930, p. 27.

57 BARgA, Corpus: Viajes por Italia, Sevilla, Renacimiento, 2003, p. 173. 
CONRAD VILANOU TORRANO E ISABEL VILAFRANCA MANGUÁN

Con independencia de esta clasificación, es innegable la presencia en España de las ideas penalistas de Cesare Lombroso (I835-1909), que influyeron en el reformismo jurídico español y en el desarrollo de la psiquiatría con el establecimiento de una tipología antropológica: el hombre criminal, el hombre delincuente, el hombre de genio, etc. Sus obras fueron vertidas a nuestra lengua y circularon profusamente en los círculos médicos y jurídicos. «La escuela lombrosiana, con sus afirmaciones y sus seguidores, defiende una ideología y unos principios en un momento determinado, en la alborada fresca y nueva del Risorgimento» ${ }^{58}$. Incluso el Boletín de la Institución Libre de Enseñanza publicó alguna colaboración suya (1893).

De tal suerte que su idea del «criminal nato» configuró una nueva disciplina -la antropología criminal- que utilizaba medidas antropométricas. Aunque con el paso del tiempo Lombroso fue objeto de críticas (por ejemplo de Broca) por la falta de rigor en el manejo de los términos y datos, lo que ponía en entredicho la validez de sus teorías y su metodología, lo cierto es que se había sembrado la semilla positivista que otros autores -como Enrico Ferri- desarrollaron extensamente. Si Lombroso priorizaba las medidas antropométricas, Ferri enfatizó la dimensión social publicando en i 884 su Sociología criminal, obra que rápidamente se tradujo y que todavía hoy se publica. De cara a nuestros intereses, conviene reparar en la aparición a comienzos del siglo pasado de su Ciencia positiva, en Barcelona, por la casa Atlante ${ }^{59}$. Por ello, Lombroso y Ferri contribuyeron -a través de la antropología y la sociología criminales- a la difusión y consolidación del ideario positivista, ya se tratara de la antropología física del primero, o bien de las observaciones psicológicas y sociológicas del segundo ${ }^{60}$. A pesar de su ideario, y de sus orígenes socialistas, Ferri no dudó en loar las excelencias del Duce, en Mussolini, nomo di Stato (1927).

\section{I. La mentalidad positivista: una tradición liberal}

Si nos circunscribimos al campo estrictamente pedagógico debemos citar los nombres de Angelo Mosso (I864-I9IO) y Roberto Ardigò (I828-I920). Mosso representa para Italia algo similar a lo que significa Claude Bernard en Francia, esto es, la difusión del método experimental que se aplicó a la fisiología, disciplina que había de convertirse en el núcleo de una nueva ciencia de la educación: la Paidología. De tal guisa que Mosso - con sus estudios sobre la fatiga y el miedo- fue uno de los apóstoles de la gimnasia y, por ende, de la regeneración social a través de la

58 Lombroso y la escuela positivista italiana, estudio preliminar de José Luis Peset y Mariano Peset, Madrid, CSIC, 1975, p. I6.

59 Ferri, Enrico: Ciencia positiva, Barcelona, Atlante, I90(?).

6o Con relación a la influencia del positivismo italiano sobre la educación española, resulta indispensable el trabajo de Ángel C. Moreu: «La recepción española de la pedagogía positivista italiana», en Hernández DíAz, José María: Influencias italianas en la educación española e iberoamericana, Salamanca, FahrenHouse Ediciones, 20I4, pp. II7-I36. 
higiene, los juegos y el cuidado de la salud. En menor medida también cabe recordar a Saverio Fausto de Dominicis, pedagogo evolucionista, estudioso de Darwin (I877) y Comte (I884), que sufrió las críticas neoidealistas de Gentile y que estampó su firma en las páginas del Boletín de la Institución Libre de Enseñanza ${ }^{61}$.

Por de pronto, en I894 apareció el libro de Mosso La educación física de la juventud, en que -entre otros aspectos- reivindicaba para Italia la "primacía en la educación física por medio de los juegos», con lo cual combatía la pretendida originalidad inglesa en cuanto a la educación física moderna al introducir los juegos y deportes en la educación. Para Mosso, la Italia del Renacimiento, con nombres como Vittorino da Feltre, Mafeo Veggio, Scanio da Salo o Hyeronimus Merculiaris, se anticipó al mundo anglosajón. Mosso reclama -de acuerdo con su concepción positiva- una base fisiológica para la educación física que así se desmarcaba de la influencia militar, de los batallones escolares implantados en Francia y de la gimnasia germánica por su violencia, exigiendo una fundamentación científica de corte fisiológico, según el modelo francés de Marey y Demeny.

El problema de la educación física no puede resolverse ni por los militares, ni por los profesores de pedagogía, ni por los maestros de gimnástica. De cualquier parte que se levanta la corteza se encontrará siempre que el fundamento de la gimnástica es un tema de fisiología. El haber puesto en minoría a los fisiólogos y a los higienistas en las comisiones que debían estudiar las reformas de la gimnástica fue la causa que retardó tal reforma en Italia ${ }^{62}$.

Bajo la influencia de la impronta fisiológica, Mosso se manifiesta partidario de una educación física de carácter civil, que sirviese para restablecer «el equilibrio entre el trabajo intelectual y el ejercicio de los músculos, que se promueva la gimnasia natural, el impulso agradable de los juegos, la carrera, el salto, las marchas y todo lo que pueda dar gracia y fuerza al hombre ${ }^{63}$. Entre otras razones, Mosso insistía en la conveniencia de no confiar la educación física a los militares, por ser poco amigos de los cambios e innovaciones, amén de la falta de cultura que asiste a los instructores castrenses, proclamando la unión de la educación física con la intelectual y moral. En síntesis, para Mosso -que utilizó las páginas del Boletín de la Institución Libre de Enseñanza para difundir sus ideas- la robusteza del organismo constituía un objetivo perentorio a fin de poder luchar contra los males de la sociedad moderna y evitar las patologías de todo tipo. Se propugnaba, pues, una solución regeneracionista que contemplaba la cuestión eugenésica enfatizando la importancia de la educación física de la mujer, de acuerdo con la siguiente fórmula: «La gimnasia femenina no será nunca una gimnasia de fuerza» ${ }^{64}$. Huelga decir que Mosso aprovechaba la ocasión para reivindicar el papel de las madres

${ }_{61}$ De Dominicis, Saverio Fausto: «La pedagogía y el Darwinismo», Boletín de la Institución Libre de Enseñanza, t. XI (1887), pp. 343-345.

${ }_{62}$ Mosso, Angelo: La educación física de la juventud, seguida de La educación física de la mujer, del mismo autor, Madrid, Librería de José Jorro, I894, p. 86.

${ }_{63}$ Ibidem, p. 159.

${ }^{64}$ Ibidem, p. 249. 
CONRAD VILANOU TORRANO E ISABEL VILAFRANCA MANGUÁN

para preservar viva la pureza de la raza por ser «celosas mantenedoras de esta herencia». Precisamente el capítulo «La educación de la mujer», incluido a modo de apéndice en La educación física de la juventud (1894), se había publicado anteriormente en el Boletín de la Institución Libre de Enseñanza (I892).

Entretanto, la gran figura del positivismo italiano fue Roberto Ardigò, hombre de formación religiosa -había sido canónigo de la catedral de Milán- que abrazó la causa cientificista, cuyas lecciones sobre La ciencia de la educación profesó en la Universidad de Padua durante los cursos 1889-90 y 1890-91, siendo recopiladas en 1903, obteniendo una extensa difusión en España. No en balde, la Biblioteca Sociológica Internacional -que promovía la casa Henrich de Barcelona- las publicó en dos tomos, sin poder precisar la fecha, aunque podemos aventurar que fue durante los primeros compases del siglo pasado. Ya en la Introducción Ardigò presentaba la Pedagogía como la ciencia del hecho de la educación, con lo cual se imponía considerar los cuatro momentos de ese hecho, esto es, actividad, ejercicio, hábito y educación, puesto que «no hay educación si no se forma el hábito, ni éste es posible sin el ejercicio, y éste supone actividad», de modo que así quedaba pergeñado el índice del libro en cuestión.

Es fácil deducir que Ardigò une la tradición aristotélica (que exalta el uso del hábito) con las aportaciones científicas modernas, basadas en la fisiología. «El fenómeno psíquico sólo ocurre como consecuencia del fenómeno fisiológico, del mismo modo que la llama tiene lugar como consecuencia de la combustión» ${ }^{65}$. Lo que propugna Ardigò no es nada más que transformar el potencial fisiológico en actividad que, a su vez, queda regulada por el ejercicio y el hábito, situando la fisiología como el fundamento de la ciencia pedagógica. Y si bien el pedagogo debe tener en cuenta el llamado registro fisiológico, razón última de la Pedagogía, no es menos verdad que la educación se basa en el hábito, después de haber demostrado que exige el cultivo de la actividad y del ejercicio. «Educar no quiere decir presentar una vez a la inteligencia los conocimientos útiles, sino generar hábitos, hacer adquirir habilidades» ${ }^{66}$. Y aunque la educación remite al hábito, no se ha de creer que todo hábito sea educación, ya que solo adquiere esta condición el hábito bueno y perfeccionador. Sobre estos supuestos de ascendencia natural -lo cual exige seguir el hilo de todo aquello que existe y se presenta con nuestra naturaleza, puesto que todo en el universo es «formación natural»- se levanta su Pedagogía entendida como Ciencia de la Educación: "porque si una Ciencia en general es el estudio de un hecho determinado, tal es el de la Educación; le hemos dado en nuestro libro toda la extensión que es dable, haciendo evidente cómo la

6s Ardigò, Roberto: La ciencia de la educación, versión española de la segunda edición italiana por Fernando y José del Río Urruti, Barcelona, Talleres de Artes Gráficas de Henrich y Compañía, sin año, tomo I, p. I9.

${ }^{66}$ ARDigò, Roberto: La ciencia de la educación, versión española de la segunda edición italiana por Fernando y José del Río Urruti, Barcelona, Talleres de Artes Gráficas de Henrich y Compañía, sin año, tomo II, pp. 135 -136. 
Educación es un hábito que se contrae por medio del Ejercicio, el cual no es a su vez sino la repetición continuada de las actividades humanas perfeccionadas» ${ }^{67}$.

Preciso es convenir que la Pedagogía entendida como Ciencia de la Educación posee también el carácter civil que Mosso reclamaba para la educación física y que Mazzini reivindicaba para la moral pública. Se trataba, pues, que la pedagogía -o mejor dicho, la Ciencia de la Educación- atendiese «las aptitudes de persona civil, de buen ciudadano y de individuo provisto de especiales habilidades útiles, decorosas, ennoblecedoras» ${ }^{68}$. La pedagogía -ya fuese a través de los manuales escolares o del discurso gimnástico- buscaba potenciar los hábitos y las aptitudes de los ciudadanos o, mejor todavía, de la persona civil, con resabios ilustrados, liberales y, lógicamente, positivistas. Más que la felicidad, había que promover los conocimientos útiles y decorosos, «con lo cual hacemos al hombre más estimable a los ojos de la sociedad entera, y ennoblecido de tal modo, que, teniendo de sí mismo un concepto elevado, acreciente su dignidad personal» ${ }^{69}$.

Pero a pesar de esta declaración de intenciones, la pedagogía positivista entró en bancarrota en Italia por diversas razones. De un lado, por una expresión neoidealista que hay que entender como una manifestación de la reacción espiritualista que se vivió en todo el sur de Europa, sobre todo, en Francia, España e Italia y que -en líneas generales- no aceptaba que la vida humana se redujese a simple materia ni tampoco que cayese en el nihilismo. De igual manera, se trata de un rechazo de la mentalidad positivista y materialista que somete al ser humano a un estado de postración ciertamente crítico, surgido de una visión meramente utilitaria de las cosas.

Después de todo, el caso italiano -en virtud de la crisis galopante del sistema liberal, dinamitado en 1922 y liquidado en 1925- provocó un alejamiento de la mentalidad positivista que se vinculó al ejercicio de la democracia liberal y, también, a la difusión del evolucionismo, a partir de un conjunto de influencias -que sin negar autores autóctonos como Ardigò- procedían del extranjero, sobre todo del mundo anglosajón (Locke, Spencer) y germano (Kant, Haeckel). Justamente, Giorgio Bassani en su narración sobre «Los últimos años de Clelia Trotti», ambientada en la Ferrara fascista, apunta que la protagonista -que vivía un tanto ocultamente para zafarse de la vigilancia de la OVRA (Obra Voluntaria de Represión Antifascista), la policía secreta del régimen- recordaba que en sus años de juventud leía a «Comte, Spencer, Ardigò, Haeckel, el del Monismo» ${ }^{70}$.

Mientras tanto llegaban a las bibliotecas especializadas de España los libros que respondían a este cambio o giro de mentalidad que comportaba una reacción espiritual de signo neoidealista, sobre todo las obras de Gentile y LombardoRadice. En menor medida, también se recibían noticias de Ernesto Codignola que era director de la revista pedagógica Levana, nombre que recuerda a la diosa

${ }_{67}$ Ibidem, tomo II, p. 137.

${ }_{68}$ Ibidem, tomo I, p. I2.

69 Ibidem, tomo I, p. I3.

7o Bassani, Giorgio: Lida Mantovani y otras historias de Ferrara, Barcelona, Barral editores, I97I, p. I67. 
CONRAD VILANOU TORRANO E ISABEL VILAFRANCA MANGUÁN

de la mitología romana ligada al reconocimiento de los niños, sin olvidar la obra homónima de Jean Paul. En fin, se transitaba del orden positivista evolucionista, fisiológico y experimental a la cosmovisión neoidealista, en una atmósfera presidida por una profunda crisis finisecular que afectaba a todas las naciones latinas. Sin forzar demasiado las cosas resulta evidente que la Paidología -expresión positivista de la ciencia de la educación- daba paso a una pedagogía de nuevo cuño, de sesgo inequívocamente filosófico, de un cariz espiritual e idealista, si bien casi siempre inmanente, que deseaba cercenar los males de la cultura moderna -sobre todo, la falta de sentido- que había encontrado en el positivismo un formidable punto de anclaje.

\subsection{Crisis de conciencia y reacción espiritual-idealista}

Parece evidente que la reacción al positivismo constituye un movimiento que se dio en Europa, coincidiendo con el proceso de crisis finisecular que afectó a las culturas latinas, sumidas en una búsqueda de identidad después de los diversos fracasos que se iniciaron con la derrota de Francia (I870) frente Alemania que acarreó la pérdida de la Alsacia y la Lorena, dinámica que Vicente Cacho Viu analizó con precisión ${ }^{71}$. De todos es conocida aquella narración de Alphonse Daudet sobre la última clase de un maestro francés, el Sr. Hamel, el patriota maestro alsaciano. De hecho, las tensiones se produjeron en lo que Salvador de Madariaga denominó las tres Hermanas Latinas, a saber, Francia, España e Italia. De cualquier modo, Madariaga deja en el tintero Portugal, cuando en España surgían voces a favor del iberismo. Sea como fuere, y a pesar de las discordias de antaño cuando España dominaba la tierra italiana, Madariaga constataba -desde su experiencia histórica y diplomática- que se da «un fuerte elemento de confraternidad procedente de la semejanza entre ambos pueblos» ${ }^{72}$. Aunque no existen situaciones idénticas, y al margen de las tensiones habidas en Italia y España, podemos establecer -en lo referente a la época contemporánea- ciertas coincidencias y paralelismos.

Así, por ejemplo, el fracaso español del 98 recuerda la derrota de la batalla de Adua (i de marzo de i896), un triste episodio de la guerra ítalo-abisinia que representó una dura humillación para el prestigio militar transalpino. El regicidio del 29 de julio de 1900 que costó la vida al rey Humberto I, padre de Víctor Manuel III, ofrece un cierto paralelismo con el atentado que ocasionó la muerte de Antonio Cánovas del Castillo -que había viajado a Italia en sus años de formación- el I8 de agosto de 1897, ambos perpetrados por anarquistas italianos. Además, la crisis vivida en España a consecuencia de la huelga general de I9I7 coincide con el desastre italiano en Caporetto en octubre de aquel mismo año. Por lo demás,

7 Cacho Viu, Vicente: «Francia I870-España I898», Revista de Occidente, n. ${ }^{\circ}$ 202-203 (1998), pp. 9-42. Para el caso italiano, puede verse el libro de Indro Montanelli El fin de siglo. La Italia de los notables (1867-1900), Barcelona, Plaza \& Janés, 1975.

72 Madariaga, Salvador de: Bosquejo de Europa, México, Editorial Hermes, I95I, p. iI2. 
el fracaso de Caporetto obligó a Italia -como sucedió en la España que siguió al 98- a una profunda reflexión que comportó una vía reformista similar al regeneracionismo hispano. Por último, la caída de la monarquía en España (193I) tuvo su réplica en el referéndum italiano de 1946, que pondría fin al régimen dinástico.

A grandes rasgos, la crisis vivida por la Restauración española que acabó con la dictadura de Primo de Rivera (1923) también nos recuerda la sufrida por el régimen constitucional italiano. En el caso italiano se contaba con líderes como Giovanni Giolitti, que presidió el gobierno en diversas ocasiones, hasta el extremo que se llega a hablar de una «dictadura giolittiana» ${ }^{73}$. Por su parte, en España-después de la desaparición de Cánovas- su lugar fue ocupado por Antonio Maura. En ambos países, empero, la crisis del sistema liberal permitió la aparición de regímenes autoritarios, en el caso italiano en 1922 y, al año siguiente, en España. A este respecto, recordamos que la marcha sobre Roma, a finales del mes de octubre de 1922, generó una dinámica que Curzio Malaparte tuvo a la vista cuando redactó su manual sobre Las técnicas del golpe de Estado (1931 ${ }^{74}$.

Sin duda alguna, no deja de ser sintomático que el libro de Lombardo-Radice -que circuló en España bajo el título de La reforma escolar italiana y que reúne un conjunto de trabajos de procedencia dispar escritos a partir de I919- refleja aquel ambiente postbelicista. La lógica de ordenación de los diferentes materiales del libro se agrupa en cuatro apartados: I) la guerra y la educación nacional; 2) vela de armas para la reforma de la escuela; 3 ) en la batalla, donde inserta las reflexiones sobre la reforma Gentile; 4) meditaciones y esperanza. Justamente en el primer texto de esta serie, menciona expresamente la derrota de Caporetto, a la vez que reclama una rehabilitación radical de la burguesía dirigente italiana:

Hay que obtener una burguesía capaz de sentir el valor del problema educación, como lo sintieron los que mandaban después de Caporetto, capaz de producir leyes escolares, de administrar la enseñanza, de seleccionar y guiar a los maestros, de desenvolver en torno a la escuela y con relación a ella una obra múltiple de asistencia social y pedagógica. ¿'Tenemos esta burguesía? No... ${ }^{75}$.

Inútil reiterar que el ambiente de crisis era una cuestión que abarca ambos países, polémica que se agravó ante la pretendida superioridad anglosajona que Edmundo Demoulins atribuyó al progreso pedagógico. En cierto sentido, aquella crisis que se gestó en el tránsito del siglo XIX al xx -preludio y anticipo de las crisis posteriores- también afectaba a las conciencias de las personas, desencadenando crisis religiosas. Croce -autor de aquella Spagna nella vita italiana durante la Rinascenza (1917), integrada en su serie de Scritti di storia letteraria e politica (vol. VIII) $-^{76}$ recuerda que su crisis religiosa fue producto de un director colegial, «pío

73 Gentile, Emilio: L'Italia giolittiana i899-1914, Bologna, Il Mulino, 1992, pp. 135-169.

74 Malaparte, Curzio: Técnicas del golpe de Estado, Barcelona, Planeta-Ariel, 2017.

75 Lombardo-Radice, Giuseppe: La Reforma escolar italiana. (Junto a los maestros), traducción y prólogo por María Victoria Jiménez, Madrid, Ediciones de La Lectura, 1927, p. 24.

${ }_{76}$ Croce, Benedetto: España en la vida italiana durante el Renacimiento, Madrid, Mundo Latino, [1919?]. Nueva versión: Sevilla, Renacimiento, 2007. 
CONRAD VILANOU TORRANO E ISABEL VILAFRANCA MANGUÁN

sacerdote y docto teólogo», quien, "poco oportunamente, se dispuso a suministrarnos a los liceístas, para reafirmarnos en la fe, algunas lecciones de "filosofía» (como él las titulaba) «de la religión»: germen lanzado a mi intelecto, ajeno hasta ese momento a aquellos problemas» ${ }^{77}$. Con otras palabras: entre los escolares a menudo la intención apologética de la filosofía de la religión conseguía efectos contrarios a los perseguidos, de modo que el historicismo de Croce -que visitó España en I889, siguiendo la estela marcada por Edmundo de Amicis- ${ }^{78}$ se alejó de la filosofía metafísica y teologizante.

También nuestro Miguel de Unamuno -que prologó la Estética de Croce-79 ejemplariza muy bien este ambiente de crisis de religión, de preocupación existencial, que acarreó en Europa el distanciamiento respecto al positivismo, la ideología que había dado sentido a los programas progresistas de la burguesía decimonónica. En este punto podemos recordar la novela El discípulo (I889) de Paul Bourget o Amor y pedagogía (1902) del mismo Unamuno, ambas críticas con el positivismo que también recibía los embates del vitalismo (Bergson), de la fenomenología (Blondel) y del misticismo (Bloy). Naturalmente, Italia no podía quedar al margen de este movimiento de despego del positivismo, tal como pone de manifiesto la trayectoria de Giovanni Papini que, a la raya de la treintena de años, escribió Un hombre acabado (1912), narración autobiográfica que describe su itinerario personal e intelectual. No olvidemos, además, que Unamuno y $\mathrm{Pa}$ pini se interesaron -y mucho- por la obra de Kierkegaard, es decir, por la cuestión del sentido de la existencia humana. No termina aquí la cosa porque Papini -entusiasmado por Don Quijote- dedicó un encomiástico trabajo a ensalzar la interpretación que Unamuno hizo del famoso personaje cervantino. Según $\mathrm{Pa}$ pini, Unamuno representa para España «algo parecido a lo que fue Carlyle para Inglaterra y Fichte para Alemania», esto es, un verdadero "apóstol espiritual» ${ }^{80}$.

Con una formación autodidacta y lector un tanto compulsivo, Papini se familiarizó con las memorias de Garibaldi («que leía y releía sin entender palabra») y las poesías de Carducci, expresando una evidente rebeldía religiosa ${ }^{81}$. «Hijo de padre ateo -escribe Papini en Un hombre acabado (I9I2)-, bautizado a escondidas, crecido sin sermones y sin misas, jamás he sufrido lo que se ha dado en llamar «crisis del alma»... Para mí Dios jamás ha muerto, porque nunca ha vivido en mi alma» ${ }^{82}$. Siendo así las cosas, algunos miembros de aquella generación finisecular no habían experimentado la muerte de Dios -anunciada por Hegel y Nietzscheporque, sencillamente, no habían sido educados en él. Por esta misma dinámica,

77 Croce, Benedetto: Aportaciones a la crítica de mí mismo, Valencia, Pre-textos, 2000, p. $2 \mathrm{I}$.

78 Croce, Benedetto: En la Península Ibérica. Cuaderno de viaje (1989), traducción, presentación y notas de Félix Fernández Murga, Sevilla, Secretariado de Publicaciones de la Universidad de Sevilla, I993.

79 CROCE, Benedetto: Estética como ciencia de la expresión y lingüística general: teoría e historia de la estética, prólogo de Miguel de Unamuno, Madrid, Francisco Beltrán, I9I2.

8o Papini, Giovanni: Retratos, Barcelona, Luis de Caralt editor, 1976 (2. ${ }^{a}$ ed.), p. 65.

8. Papini, Giovanni: Un hombre acabado, Barcelona, Editorial Argos Vergara, 1980, p. I8.

82 Ibidem, p. 20. 


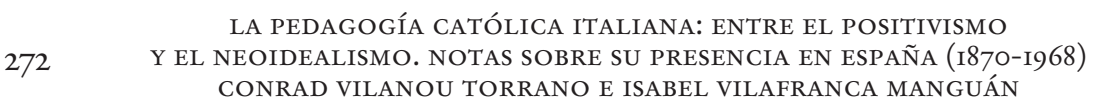

el positivismo fue una puerta a la esperanza en la búsqueda de soluciones, sin obtener una respuesta convincente. Bajo su influjo, Papini -uno de los intelectuales católicos italianos que mayor incidencia ha tenido en España- ${ }^{83}$ se arrojó a los I8 años (hacia i899) sobre la antropología, psicología, biología y sociología, sin obtener una respuesta convincente. «Me sentía ahogado por los hechos, pero los hechos no me bastaban. Por más que los sondeara y los reuniera no agotaban el infinito. Aquella riqueza del hecho particular, que había sido mi única riqueza de erudito desordenado, me parecía una miseria desesperada» ${ }^{84}$.

Añadamos que, aunque Papini nunca nos visitó a pesar de las invitaciones que recibió, pronto se pasó al bando contrario. Desde luego perdió su fe positivista y abrazó la causa espiritualista que le condujo hasta el catolicismo. «La filosofía dominante durante aquellos años en Italia era el positivismo, y nosotros nos propusimos dar la batalla a los positivistas» ${ }^{85}$. Diversos pasajes de Un hombre acabado insisten en este cambio de actitud. "Yo combatía el positivismo porque los positivistas pretendían que no eran otra cosa que notarios remisivos de la realidad: me apasionaba por el idealismo y lo impedía hasta sus últimos extremos, porque el espiritualizar excesivo y el dudar hasta de la existencia del cuerpo rayaba en extravagancia y en paradoja» ${ }^{86}$.

Bien es cierto que en Italia el idealismo había cuajado a través de las enseñanzas de Bertrando Spaventa, representante del hegelianismo napolitano y pariente de Croce, quien -a escondidas de las recomendaciones de su familia- frecuentó sus clases sin identificarse. Recordemos las palabras que Corpus Barga escribió en 1920 sobre esta aproximación al idealismo, con relación al pensamiento de Croce: «Spaventa es la nacionalización de la filosofía en Italia. Su obra es la idealización en lo italiano, acaso mejor que del pensamiento del universo, del pensamiento de Alemania, quiero decir, del pensamiento nacional» ${ }^{87}$. Corpus Barga en aquella temprana ocasión -nos referimos a la serie de artículos que publicó en El Sol, sobre su visita a Croce (1920)- recordaba que la importancia de Hegel en Italia se remontaba a I86I «en la Universidad de Nápoles, en la que profesaba, además de Spaventa, otro hegeliano, el viejo hegeliano Augusto Vera... De Vera al actual profesor de Roma il Gentile -sucesor de Croce, dentro de la historicidad del pensamiento italiano- se cultiva en Italia la idealidad de Hegel» ${ }^{88}$. En opinión de Corpus Barga lo que significó el krausismo en la España regeneracionista y finisecular, en Italia estuvo representado por la filosofía de Hegel.

Si damos crédito a Croce, sabemos del gusto y la fe que aquella Italia finisecular sentía por el «libro alemán» formándose un frente idealista en el que participaron Gentile y Croce, que acabaron por distanciarse. De un lado, Croce

83 IRIARTE, Joaquín: «Papini y sus modos de intelectual florentino», Razón y Fe, I55 (1957), pp. II2-I22.

${ }^{84}$ PAPINI, Giovanni: Un hombre acabado, op. cit., p. 67.

85 Ibidem, p. 95.

${ }^{86}$ Ibidem, p. IO2.

${ }^{87}$ BARgA, Corpus: Viajes por Italia, op. cit., p. 174.

${ }_{88}$ Ibidem, pp. 174-175. 
LA PEDAGOGÍA CATÓLICA ITALIANA: ENTRE EL POSITIVISMO

Y EL NEOIDEALISMO. NOTAS SOBRE SU PRESENCIA EN ESPAÑA (I870-I968)

CONRAD VILANOU TORRANO E ISABEL VILAFRANCA MANGUÁN

defendió un historicismo que también llegó a las escuelas secundarias italianas a través de su Breviario de estética (1913), obra que ha tenido una gran acogida en España, especialmente durante el franquismo ${ }^{89}$. Por otra parte, Gentile -autor del Sommario di Pedagogia Generale, publicado en dos volúmenes durante el bienio I9I3-I4, siendo vertido al español en Buenos Aires en 1946- sostuvo a través de su Teoría general del espíritu como acto puro (I9I2) un actualismo que ve la vida como una expresión del Espíritu, superando el hiato entre pensamiento y acción, viejo tema presente en Kant, Schiller y Fichte, todos enfrascados en la búsqueda de la unidad, ya que el logos no es algo AвSTRACTo, «sino actualidad viva y real del logos concreto» ${ }^{90}$. Se ha dicho que mientras Marx es una respuesta a Hegel, Gentile -con su actualismo que reúne el pensamiento y la acción- pretende ser una alternativa a Marx ${ }^{91}$.

Mientras Croce -que junto a Gentile había puesto en marcha en $1903 \mathrm{La} \mathrm{Cri-}$ tica. Rivista di Letteratura, storia e filosofia-describió la historia en clave estetizante, Gentile diluyó la pedagogía en la filosofía. Si para Croce -emulando a Dilthey- todo se reduce a historia, para Gentile -de acuerdo con Hegel- todo es espíritu en el que se integran el arte y la religión. A fin de cuentas, la historia y el espíritu tienden a la unidad, a un monismo que conglutina el pensamiento y la acción. No extraña, pues, que Norberto Bobbio escribiese lo siguiente:

Gentile fue el filósofo de la unidad por excelencia, de la reducción de todo en todo... Luego de los primeros años de ejercicio de historiador de la filosofía, por lo demás ejemplares por su excepcional precocidad, en los cuales pasó rápidamente de Rosmini y Gioberti a Marx y de Marx a Bertrando Spaventa, dio inicio a su carrera de filósofo teórico resolviendo un campo tan rico de determinaciones concretas como la pedagogía en uno-todo de la filosofía del espíritu, a la cual reduciría todas las formas del saber concreto a medida que se fuera topando con ellas, como si fueran piedras que obstaculizaran el camino que conduce fatalmente al no-saber de la filosofía del acto ${ }^{92}$.

Por su parte, Croce dibujó qué representó para la historia italiana aquella reacción espiritual-idealista que propició el entronque con el idealismo: «Per effetto di questa reazzione, l'orizzonte spirituale ampliò la sua distesa, grandi idee offuscate tornarono a rifulgere, fecondi metodi logici furono ritentati, rinacquero coraggio e ardire per le speculazioni, si riaprirono i libri dei grandi filosofi antichi e moderni, anche di quelli un tempo più abrominati, comme il Fichte e lo Hegel» ${ }^{93}$.

89 Croce, Benedetto: Breviario de Estética. Cuatro lecciones seguidas de dos ensayos y un apéndice, Madrid, Espasa-Calpe, 1942 (3. ${ }^{a}$ ed.) [I. ${ }^{a}$ ed., 1938].

90 Uscatescu, George: «Giovanni Gentile, filósofo europeo», Crisis, 7-8 (julio-diciembre 1955), p. 465 .

${ }_{91}$ Fusaro, Diego: Idealismo e prassi. Fichte, Marx e Gentile, Génova, El Melangolo, 2013.

92 Bоввіо, Norberto: Ensayos sobre el fascismo, selección de textos, traducción e Introducción de Luis Rossi, Bernal, Universidad Nacional de Quilmes-Buenos Aires, Prometeo Libros, 2006, p. 108.

93 Croce, Benedetto: Storia d'Italia dal I871 al I915, a cura di Giuseppe Galasso, Milano, Adelphi Edizioni, I99I, pp. 310-3II. 
Desengañado del positivismo y del socialismo, Papini hizo un giro hacia el catolicismo con una inequívoca intención patriótica: «Después del año I860 no existía un pensamiento único, italiano. Era el momento de ponerse de nuevo en camino. Una nación que no siente en sí la pasión mesiánica está destinada a desaparecer» ${ }^{94}$. Así se explica la reacción antipositivista de fines del siglo xIX y comienzos del $\mathrm{xx}$, que puede entenderse como el retorno al principio romántico (Fichte, Pestalozzi, Froebel, etc.) de la libre actividad espiritual e individual, gracias a la cual el ser humano construye su mundo, principio que alentó el neoidealismo en connivencia con el movimiento de la Escuela Nueva, representada en Italia por Lombardo-Radice ${ }^{95}$. En última instancia, se dieron vasos comunicantes durante el fascismo entre el neoidealismo que sirvió de base ideológica para la reforma educativa iniciada por Gentile y la educación activa, al proclamar Lombardo-Radice que uno de los objetivos era facilitar el desarrollo espontáneo del niño.

Vale decir que Papini en su Diario -escrito mayoritariamente durante los años de la Segunda Guerra Mundial, a modo de descargo de conciencia con la intención de justificar su actuación- dejó constancia de este trasfondo intelectual, cuando bajo los Saboya-Humberto I y Víctor Manuel III- se impuso un régimen liberal que, paulatinamente, fue entrando en decadencia hasta llegar al fatídico otoño de 1922. En la anotación del 7 de abril de 1944 -escasos días antes de la muerte de Giovanni Gentile en Florencia a manos de partisanos gappisti- Papini escribió: «Cuando empecé a pensar, hacia I896, dominaba en Italia el positivismo evolucionista de origen inglés; desde 1904 en adelante se difundió el idealismo de origen alemán y el pragmatismo de origen americano; hace tres o cuatro años que ha sido importado el existencialismo de origen escandinavo-eslavo (Kierkegaard, Dostoyevski)» ${ }^{96}$. A renglón seguido anotaba: «No hay una filosofía estrictamente italiana, por lo menos en nuestros tiempos. Croce es nuestro Kant; Gentile, nuestro Fichte; esperamos un Schelling y un Hegel» ${ }^{97}$.

El i4 de julio de 1944, cuando la derrota del fascismo era cosa segura, y aprovechando la festividad de san Buenaventura, Papini fue admitido en la Orden Tercera de San Francisco. Con este gesto, sellaba su compromiso con el catolicismo, a la vez que ponía de manifiesto que en Italia todo estaba por hacer desde el prisma del pensamiento, si tenemos en cuenta que en su opinión Croce ocupaba el lugar de Kant y Gentile el de Fichte. Desde nuestra perspectiva, quizá no sea así porque Gentile se nos presenta no solo como un bastión al positivismo, sino también como el más preclaro representante de la pedagogía neoidealista, un epígono de Hegel, un auténtico neohegeliano. Pero tampoco podemos olvidar que Gentile escribió La reforma dell'educazione. Discorsi ai maestri di Trieste (1919), fruto de unas conferencias pronunciadas en aquella ciudad que acababa de integrarse a Italia y dictadas durante el verano con destino a los maestros, defendiendo la

94 Papini, Giovanni: Un hombre acabado, op. cit., p. 128.

95 Aliotta, Antonio: Disegno storico della Pedagogia dal punto de vista filosófico, Roma, Cremonese, 1955, p. 357.

96 Papini, Giovanni: Diario, Barcelona, Editorial Mateu, 1963, p. I49.

${ }_{97}$ Ibidem, p. I49. 
LA PEDAGOGÍA CATÓLICA ITALIANA: ENTRE EL POSITIVISMO

Y EL NEOIDEALISMO. NOTAS SOBRE SU PRESENCIA EN ESPAÑA (I870-I968)

CONRAD VILANOU TORRANO E ISABEL VILAFRANCA MANGUÁN

nacionalización de la educación, una vez consumada la obra del Risorgimento. «Di modo che questo Stato che è il Regno d'Italia, nè può dirsi, in verità, cominciato nel I86I, quando fu votata in parlamento la legge per la proclamazione del Regno, nè si compì a Roma nel I870, nè a Trieste il 3 novembre I9I8» ${ }^{98}$.

Si en I918 Gentile hacía un papel parecido al Fichte de los Discursos a la nación alemana (1808), sus reflexiones pedagógicas -que habían cristalizado en el Sommario di Pedagogia (1913-1914) - responden a una convicción netamente hegeliana. De hecho, el mismo Gentile -en un breve trabajo sobre «Il pensiero pedagogico di Hegel»- señala que al fundar la pedagogía en la fenomenología del espíritu -el espíritu entendido como libertad, desarrollo y autoconciencia infinita- se convierte en «il più grande dei pensatori a cui la pedagogia debe il suo sviluppo scientifico» ${ }^{99}$. No por azar, Xirau señaló -al comentar desde las páginas de la $R e-$ vista de Pedagogía en 1923 la obra Educazione e Scuola laica-que la pedagogía de Gentile procede en línea recta de Hegel ${ }^{100}$. Como recuerda Uscatescu, que fuera discípulo de Gentile, para Hegel el espíritu se realiza a través de las formas históricas mientras que según Gentile el «Estado es actividad del Espíritu, un proceso en permanente revolución» ${ }^{101}$. Sin embargo, existen diferencias entre ambos: si Hegel sostiene un pensamiento pensado, Gentile aboga por un pensamiento pensante, en que se unifica el pensar y la acción, con lo cual «lo real es, pues, el pensamiento en su desarrollo dialéctico, en su eterno hacerse, como acto puro» ${ }^{102}$. El éxito de Gentile llegó a ser tal que el Seminario de Pedagogía de la Universidad de Barcelona, fundado por Xirau en I930, invitó a Gentile, que debió declinar tal distinción al no poderse documentar su presencia en la Ciudad Condal.

En el fondo, Gentile -un auténtico intelectual orgánico que se sirve de la pedagogía para convertirse en una especie de educador del pueblo- vio en el fascismo la consumación de un largo proceso histórico que unía el Renacimiento con el Risorgimento y este con el fascismo. De esta manera, se generó una conciencia nacional, un concepto de nación, en sintonía con la idea de un nuevo Estado patriótico distinto al demoliberal egoísta y decadente, esto es, el Estado-ético del fascismo que -en un primer momento-despertó el afecto del mismo Bobbio. «Me parecía imposible, dado que Gentile era fascista, que el fascismo estuviese equivocado; si el régimen era un Estado ético, con toda aquella ristra de palabras grandilocuentes que una definición de este género arrastraba, este Estado no podía ser injusto» ${ }^{103}$. Con el paso del tiempo, Bobbio fue invitado a revisar su

98 Gentile, Giovanni: La Riforma dell'Educazione. Discorsi al maestri di Trieste, quarta edizione riveduta, Firenze, G. C. Sansoni, editore, 1935, p. I3.

99 Gentile, Giovanni: «El pensiero pedagógico di Hegel», en Scritti Pedagogici. I. Educazione e scuola laica, quarta edizione riveduta e accresciuta, Firenze, G. C. Sansoni, editores, 1937, p. 356.

ıo Recensión de J. Xirau al libro de G. Gentile, Educazione e scuola laica en Revista de Pedagogía, II, 22 (octubre I923), pp. 396-398.

ror Uscatescu, George: «Giovanni Gentile, filósofo europeo», op. cit., p. 463.

ro2 Sciacca, Michele Federico: Filosofía, hoy. De los orígenes románticos de la filosofía contemporánea hasta los problemas actuales, op. cit., p. 57 .

ıо Воввіо, Norberto: Ensayos sobre el fascismo, op. cit., p. Iо6. 
posición respecto a Gentile, señalando el conservadurismo y la tendencia a la unidad como sus dos notas más características.

Tampoco cabe la menor duda sobre la influencia de Gentile en España, ya fuese directamente en los años de apogeo del fascismo, o a través de discípulos como George Uscatescu que en I955-en su intervención en el Congreso de Estudios Filosóficos dedicado a Giovanni Gentile, en Florencia, ciudad en que reposan sus restos en la basílica de la Santa Cruz- recordaba sus clases, con un encendido elogio del idealismo gentiliano que representaba «en esencia y en la medida en que inspira su filosofía política la creación de una nueva jerarquía de valores, la máxima reivindicación del papel fecundo de las elites revolucionarias y una fecunda orientación de los esfuerzos revolucionarios de nuestro tiempo» ${ }^{104}$. A continuación, apostillaba: "Concebir el Estado como radical eticidad es, no cabe duda, la única solución salvadora» ${ }^{105}$, en un todo en que la moralidad del individuo no puede ser diferente a la moralidad del Estado. Precisamente en su adhesión al Partido Fascista, en una carta dirigida a Mussolini, el 3I de mayo de I923, después de una visita del secretario general del Partido, Michele Bianchi, y del secretario federal de Roma, Giovanni Vaselli, Gentile reconoció que gracias a su profunda convicción liberal, y por lealtad a los hombres que guiaron la Italia del Risorgimento, aceptaba ingresar en el Partido que garantizaba un Estado fuerte concebido como una realidad ética, donde podía realizarse su pensamiento liberal ${ }^{106}$.

En suma, el stato etico se convierte en algo absoluto, en una necesidad que no puede existir sin un substrato nacionalista, patriótico y totalizante, que lo aleje de cualquier tentación particular e individualista, según defienden los regímenes demoliberales. Veamos las siguientes palabras que forman parte de su conferencia Che cosa è il Fascismo, dictada el 8 de marzo de i925:

Lo Stato etico del fascista non è più -s'intende- lo Stato agnostico del vecchio liberalismo. La sua eticità è spiritualità: personalità che è consapevolezza; sistema che è volontà. E sistema vuol dire pensiero, programa. Vuol dire storia d'un popolo raccolta nel fuoco vivo di una coscienza attuale e attiva. Vuol dire concetto di quel che si è, si può e si debe essere: vuol dire missione e proposito, in generale e in particolare, remoto e prossimo, mediato e inmediato, tutto determinato. Lo Stato è la grande volontà della nazione; e perciò la grande intelligenza ${ }^{107}$.

Ahora bien, y tal como recoge Luis Rossi en la Introducción a los Ensayos sobre el fascismo de Bobbio -que como hemos visto confiere un papel central a la figura de Gentile-, el idealismo gentiliano es anterior al fascismo: «La vigencia del idealismo en la cultura italiana durante los primeros años del fascismo prueba la existencia

104 Uscatescu, George: «Giovanni Gentile, filósofo europeo», op. cit., p. 460.

105 IBIDEM, p. 463.

106 Gentile, Giovanni: «Adesione al Partido Fascista», en Scritti Pedagogici. III. La Riforma della Scuola in Italia, seconda edizione, Firenze, G. C. Sansoni-editore, 1937, pp. I27-I28.

${ }^{107}$ Edición electrónica: bibliotecaitalica.files.wordpress.com [fecha consulta: 9 de diciembre de 20I4]. 
LA PEDAGOGÍA CATÓLICA ITALIANA: ENTRE EL POSITIVISMO

Y EL NEOIDEALISMO. NOTAS SOBRE SU PRESENCIA EN ESPAÑA (I870-I968)

CONRAD VILANOU TORRANO E ISABEL VILAFRANCA MANGUÁN

de una línea de continuidad entre la época anterior al fascismo y la fascista, pero no bajo el signo partidario, sino como muestra de la vitalidad de una tradición que en Italia se remontaba hasta mediados del siglo XIX» ${ }^{108}$.

Seguramente, Papini y Gentile profesaban un fuerte sentido nacionalista y, al mismo tiempo, una reticencia hacia el experimentalismo de la ciencia positiva. Papini -después de coquetear con el fascismo- se mantuvo fiel a la causa de Cristo, mientras que Gentile -un intelectual al servicio del fascismo, si bien fraguó su pensamiento con anterioridad a la marcha sobre Roma- abogó por un idealismo que encontraba en el Estado-ético la mejor expresión de la libertad individual. Baste decir que si muchos criticaron su pensamiento, silenciado en parte después de 1945 (no encontramos, por ejemplo, referencias importantes en la revista Cultura e Scuola, que empezó su singladura en i963), dejó su impacto en los pensadores espiritualistas como Michele Federico Sciacca, quien no escatimó los elogios: «Hombre rico de generosa humanidad, maestro eficacísimo, entendió el filosofar como proceso ético y educativo, a la filosofía, como vida perenne del pensamiento que es conciencia de sí» ${ }^{109}$. Por su parte, George Uscatescu, que siguió las clases de Gentile en Roma y le acompañó durante la radiodifusión del Discorso agli italiani (1943), reconoce que el lenguaje conceptual gentiliano posee unos términos que «son esencialmente cristianos», ascendencia que permitía que sobre las bases neoidealistas cuajara un pensamiento espiritualista que entroncaba hacia atrás con el agustinianismo y el pensamiento del Risorgimento y permitía, después de la guerra civil vivida por Italia entre 1943 y 1945, dar viabilidad a una manera de hacer cristiana y espiritual que defiende un idealismo que deriva de Dios y que, por ende, rectifica el rumbo inmanente del actualismo gentiliano.

Si alguna cosa positiva podemos sumar en el haber de Giovanni Gentile -que se hizo fascista por convicción- es, precisamente, su lealtad al fascismo durante todo el Ventennio, período comprendido entre la marcha sobre Roma (el 30 de octubre de 1922 llegaba Mussolini a la estación Termini de Roma) y la destitución del Duce el 25 de julio de i943. Aquí podemos traer a colación que Gentile fue ministro en el primer gobierno Mussolini, constituido el 3I de octubre de I922, cuando aparentemente se mantenían las formas liberales, aplicando inmediatamente su famosa reforma cuyas primeras disposiciones se adoptaron en el mes de diciembre de i922.

Con el paso del tiempo, Gentile quedó un tanto relegado a una posición periférica, como recuerda Bobbio, sobre todo después de la firma de los Pactos de Letrán (1929). A pesar de ello siempre se mantuvo leal a la causa fascista, proclamando la vigencia del régimen en 1943 cuando pronunció, el 24 de junio, el Discorso agli italiani desde el Campidoglio romano haciendo un llamamiento a la pacificación. Poco después de la jornada del 25 de julio de i943, fue desautorizado por el nuevo ministro Leonardo Severi, antiguo colaborador suyo integrado

${ }_{108}$ Bоввіо, Norberto: Ensayos sobre el fascismo, op. cit., p. 24.

rog Sciacca, Michele Federico: Filosofía, hoy. De los orígenes románticos de la filosofía contemporánea hasta los problemas actuales, op. cit., p. 56. 
LA PEDAGOGÍA CATÓLICA ITALIANA: ENTRE EL POSITIVISMO
278 Y EL NEOIDEALISMO. NOTAS SOBRE SU PRESENCIA EN ESPAÑA (I87O-I968)
CONRAD VILANOU TORRANO E ISABEL VILAFRANCA MANGUÁN

en el primer gabinete de Badoglio, perdiendo incluso su condición de consejero del Ministerio de Educación Nacional que había dirigido unos años antes ${ }^{110}$. A continuación, se adhirió a la República Social Italiana, la República de Salò, manteniendo su actividad entre Florencia y Pisa. Su muerte en las calles florentinas el is de abril de i944 era, pues, una crónica anunciada que despierta aún hoy un sinfín de polémicas y constituye para algunos una cuestión abierta que genera una extensa literatura ${ }^{111}$.

\subsection{El neoidealismo de Gentile: la disolución de la pedagogía en la filosofía}

Resulta evidente que Italia optaba -como hizo Alemania durante la primera mitad del siglo xIx- por la solución idealista, orillando el realismo herbartiano, al que Gentile censuraba la tendencia al dualismo que lo aleja de la ansiada unidad. Por contrapartida, sabemos que el pensamiento de Herbart -una especie de alternativa a Hegel- triunfó en los ambientes austríacos, propiciando «la simpatía de experimentalistas como Fechner y Wundt, que harían frecuente uso de su concepto de "apercepción»»" ${ }^{112}$. De tal guisa que esta situación también puede interpretarse como una respuesta al idealismo hegeliano que cuajó en Prusia, mientras la Austria católica seguía los pasos del realismo herbartiano.

Tanto es así que algunos historiadores han destacado la impronta herbartiana de la reforma educativa austríaca, que formó a algunos de los líderes católicos italianos como Alcide de Gasperi, que procedía del Trentino, considerado hoy uno de los padres de la actual Europa. Un especialista de la historia intelectual como Johnston enfatiza la facilidad con que la filosofía herbartiana casaba con los postulados católicos, cosa que se hace evidente en la pedagogía alemana con figuras señeras como Otto Willmann, circunstancia que no sucedía con el neoidealismo. «En cuanto a sus ideas, al erigirse en abanderado de una postura intermedia entre idealismo y empirismo parecía estar trazando un paralelo con la vía media de santo Tomás de Aquino» ${ }^{113}$. Si los partidarios de Herbart en el imperio austrohúngaro fraguaron una oposición a la filosofía hegeliana, no sucedió lo mismo en Italia, donde cuajó con fuerza a través del actualismo neoidealista, que frenó la difusión de la pedagogía herbartiana. Llegados a este punto, cabe insistir en que desde la perspectiva gentiliana el error de Hegel es haber destacado la importancia de lo pensado, mientras que el actualismo enfatiza la importancia del acto del sujeto pensante, lo cual confiere un dinamismo infinito al acto del pensamiento al incluir en un todo que conglutina el pensar y la acción, de modo que se articula un hacer activo, planteamiento amable a los defensores de la Escuela Nueva.

по Herraiz, Ismael: Italia fuera de combate, Madrid, Ediciones Atlas, 1944, p. 265.

III Mecacci, Lucciano: La Ghirlanda fiorentina e la morte di Giovanni Gentile, Milán, Adelphi edizioni, 2014.

${ }_{12}$ Johnston, William M.: El genio austrobúngaro. Historia social e intelectual (1848-1938), Oviedo, Krk ediciones, 2009, p. 66r.

${ }^{113}$ Ibidem, pp. 665-666. 
LA PEDAGOGÍA CATÓLICA ITALIANA: ENTRE EL POSITIVISMO

Y EL NEOIDEALISMO. NOTAS SOBRE SU PRESENCIA EN ESPAÑA (I870-I968)

CONRAD VILANOU TORRANO E ISABEL VILAFRANCA MANGUÁN

Nótese que el actualismo de Gentile perfila un esquema ternario -arte, religión, filosofía- que son las únicas formas absolutas de la realidad espiritual. Según este proceder, el espíritu sigue el itinerario dialéctico marcado por el arte, la religión y la filosofía, de tal manera que al arte (momento de la conciencia del sujeto) sigue la religión (entendida como ciencia del objeto), quedando ambos englobados en la filosofía. Por ello, la pedagogía no puede depender del arte ni tampoco de la religión, sino de la filosofía globalmente considerada, ya que en ella se fusionan los dos primeros momentos del espíritu, a saber, el arte y la religión, que se dan hermanados en la cultura del pueblo, una voz que el fascismo intentará recoger y alentar. En definitiva, la pedagogía se equipara a la filosofía, hasta el extremo de diluirse en ella.

Como es natural, la reducción de la pedagogía a la filosofía -según expone en el Sommario di Pedagogia, obra en dos volúmenes (I. Pedagogía general, II. Didáctica) con que se inician sus obras completas- ${ }^{114}$ sigue la misma dinámica a fin de simplificar los dos aspectos -el hecho y el ideal-del problema pedagógico. Al resultar imposible prescindir de ambos referentes y, por tanto, de las consideraciones psicológicas y éticas, es inviable reducir la psicología a pedagogía psicológica y la ética a pedagogía ética. En el primer caso, se caería en una pedagogía mecanicista de índole positivo-experimental y en el segundo en una pedagogía normativa, sin un sólido fundamento científico-espiritual. Contrario, pues, al esquema herbartiano que mantiene el abismo abierto entre ambos polos, entre el ser psicológico y el deber-ser normativo, Gentile apuesta por la unificación a fin de resolver la cuestión gnoseológica de la pedagogía, superando el dualismo psicología-ética. «Allora non c’è più una psicología e un’etica tra cui scegliere: c’è la filosofia, e s'impone il concetto che la pedagogia è la filosofia» ${ }^{115}$.

Al margen de su particular combate contra el herbartismo -que a fines del siglo XIX vivió una época esplendorosa de la mano de los neoherbartianos (Rein, Stoy, Ziller, etc.), cuyas obras circulaban por toda Europa llegando también a España-, la pedagogía de Giovanni Gentile interesaba por su peculiar defensa del laicismo que situaba la cuestión religiosa -un viejo tema con tintes decimonónicos- en una nueva coyuntura. Si tradicionalmente los defensores del laicismo querían apartar la religión de la escuela, según el modelo clásico de la III República francesa, el neoidealismo proclamaba la conveniencia de la religión en la escuela para defender, justamente, su laicidad. Esto hizo que la filosofía de la religión de Gentile también generase muchos ríos de tinta, siendo acusado de mantener

${ }^{114}$ Diversos volúmenes de las obras completas (Opere complete) de Gentile, a cargo de la casa Sansoni de Florencia, vinculada a los intereses de la familia Gentile, están dedicados a la educación. Además de las dos primeras entregas que reúnen el Sommario di Pedagogia come scienza filosofica, detallamos los siguientes volúmenes: La Riforma dell'educazione (VII), Educazione e scuola laica (XXXIX), La reforma della scuola in Italia (XLI).

is Gentile, Giovanni: Sommario di Pedagogia comme scienza filosofica. I. Pedagogia Generale, Firenze, G. C. Sansoni, editore, 1942, 5. ${ }^{a}$ ed., p. II9. [La traducción dice lo siguiente: «No ha habido ya una psicología y una ética entre las cuales escoger: hay una filosofía. Y se ha impuesto el concepto de que la Pedagogía es la Filosofía»]. 
una posición claramente inmanente, desde el momento que no hacía depender el espíritu de la luz divina como sostendrían los espiritualistas cristianos, en la línea agustiniana. Así, M. F. Sciacca dejó claro que «el actualismo, a pesar de sus buenas intenciones, si no es una filosofía irreligiosa o antireligiosa, es en rigor de verdad una filosofía laica y regida por el pensamiento, es decir, arreligiosa» ${ }^{116}$. En resumidas cuentas, la religión -como el arte- quedaría subsumida por la filosofía y, por ende, por el espíritu en su devenir histórico.

Pues bien, Gentile, el 9 de febrero de 1943 -a las puertas del ocaso del fascismo-, expresó públicamente su posición religiosa en una intervención en el Aula Magna de la Universidad de Florencia titulada La mia religione. Es más que posible que en sus palabras resonasen los ecos del pensamiento de Joaquim de Fiore con su teoría de las tres edades (del Padre, del Hijo y del Espíritu) y, naturalmente, de Hegel para quien la razón ha suplantado a la providencia divina. Aunque mantuvo su confianza en el Estado laico, Gentile hizo entonces profesión de su fe cristiana e, incluso, de su filiación católica. «Sono cristiano perché credo nella religione dello spirito». A continuación señalaba: «Perché cristiano, l’ho detto. La religione cristiana è la religione dello spirito, per la quale Dio è spirito; ma è spirito in quanto l'uomo è spirito; e Dio e uomo nella realtà dello spirito sono due e sono uno: sicché l'uomo è veramente uomo soltanto nella sua unità con Dio: pensiero divino e divina volontà» ${ }^{117}$.

Unas líneas más adelante apuntaba: «Il cristianesimo è impregnato da questo concetto dell'unità, non del cosmo o della natura, ma dello spirito. Che non è realta molteplice. Perchè la molteplicità con la negatività reciproca de’ suoi elementi è meccanismo, o materia comunque si battezzi».

En cualquier caso, y ante la confesión religiosa de Gentile, algo similar hizo Croce, hasta el punto de que Papini -siempre ortodoxo- registra el I4 de febrero de 1943 en su diario lo siguiente refiriéndose en primer lugar a Gentile: «Su cristianismo es, a su manera, de marca hegeliana. Ni uno ni otro (aqui se refiere a ambos, a Gentile y Croce) han modificado substancialmente su propio pensamiento; pero ¿por qué precisamente ahora y a tan breve distancia uno del otro se reconcilian para proclamarse cristianos» ${ }^{118}$.

Este doble atractivo de la filosofía de la educación de Gentile -la oposición al herbartismo y la defensa de la religión para mantener la laicidad escolar- explica el éxito de sus doctrinas que fueron seguidas de cerca en España. En este orden de cosas, Orencio Muñoz -desde las páginas de la Revista de Pedagogía e impresionado por una reforma aplicada en poco menos de un año-deseaba importarla, presentando a Gentile en la galería de pedagogos contemporáneos ${ }^{119}$. Haciéndose

Ir6 Sciacca, Michele Federico: Estudios sobre filosofía moderna, op. cit., p. 458.

${ }^{117}$ Edición electrónica: filosófico.net/Antologia_file/AntologiaG/gentilerz.htm [fecha consulta: 9 de diciembre de 20I4].

II8 Papini, Giovanni: Diario, op. cit., p. IO2.

19 Sobre la reforma Gentile existe una extensa bibliografía, entre la que destacamos las páginas que Francisco Morente Valero dedica en su libro «Libro e Moschetto». Política educativa y política de Juventud en la Italia fascista (1922-1943), Barcelona, PPU, 200I, pp. 43-73. A pesar de su tono 
CONRAD VILANOU TORRANO E ISABEL VILAFRANCA MANGUÁN

eco del Sumario de Pedagogía, destacaba que el idealismo del ministro italiano -«un idealismo monista, absoluto»- resuelve la dualidad sujeto-objeto en la actualidad del espíritu o inmediatabilidad del acto espiritual, en la autoconciencia de la conciencia o conocimiento de nosotros por nosotros mismos». Seguidamente apostilla: «La realidad -el Yo real- no existe, no es, se hace; no es un becho, sino acto, proceso: autoctisi, un hacerse» ${ }^{120}$.

Sin embargo, no acaba aquí la cosa porque, bajo la atracción de la reforma gentiliana, Orencio Muñoz - maestro y abogado- aplaude la solución religiosa que plantea Gentile en el sentido de mantener la religión en la escuela elemental para prescindir de ella en la secundaria, al quedar supeditada y substituida por la filosofía. «No debe, pues, arrojarse a la religión de la escuela, sino mantenerla en sus primeros estadios, con el fin de elaborarla y superarla con el crecer de la conciencia» ${ }^{121}$. Para este comentarista, contrario al intervencionismo vaticanista, el examen de Estado era un acierto, sin olvidar que la religión quedaba subsumida en la filosofía, entendida como principio unificador en la conciencia del educando, lo cual situaba al Estado por encima de la Iglesia, porque tiene «algo mejor que una religión: una filosofía, que también es fe; pero con esta diferencia de la religión: que su objeto no trasciende a la razón ni a la voluntad humana» ${ }^{122}$.

Contrario a las pretensiones de la corriente paidológica por su carga positivoexperimental, Gentile también se desmarcaba de los partidarios de la escuela unificada formulando una alternativa selectiva criticada por Gramsci, que buscaba reducir y mejorar el número de escuelas medias a fin de desencadenar la anhelada reacción espiritual-idealista. Por consiguiente, se recurría al estudio de las humanidades, sobre todo de la filosofía, sin desdeñar las lenguas clásicas y, menos aún, el italiano. La literatura ambientada en la época recoge este apego educativo por las humanidades en la enseñanza media, con la presencia significativa de las clases de griego, latín e italiano. Giorgo Bassani en su narración Dietro la porta (I964), sobre sus años de aprendizaje en la Ferrara fascista, recoge las dificultades de algunos profesores especialistas en otras disciplinas que se vieron obligados a explicar filosofía, demostrando no gran pericia en la interpretación de los textos platónicos.

divulgador, hemos tenido a la vista el libro de Italo Del Neri: L'educazione fascista. Le organizzazioni giovanili maschili e femminili, la scuola, i libri i giornalini, l'arte, l'educazione física, Savona, Marco Sabatelli editore, 20I4, con referencias sintéticas a todo el proceso escolar y pedagógico-social del fascismo.

${ }_{120}$ MuÑoz, Orencio: «Giovanni Gentile», Revista de Pedagogía, n. 26 (febrero 1924), pp. 53-54. $\mathrm{Si}$, en este primer artículo, el autor analizó la dimensión filosófica y pedagógica de Gentile, en la continuación [Revista de Pedagogía, n. ${ }^{\circ} 2$ (marzo 1924), pp. 96-IO2] pasó revista a la dimensión política.

${ }^{121}$ Orencio MuÑoz también recensionó para la Revista de Pedagogía las obras de G. Lombardo-Radice, Saggi di propaganda politica e pedagogica (1910) y Nuovi saggi di propaganda politica e pedagogica (1922) [Revista de Pedagogía, n. 32 (agosto 1924), pp. 312-316 (la cita corresponde a la página 314)]. Con anterioridad, se interesó por la obra Educazione e diseducazione, del mismo autor [Revista de Pedagogía, n. 28 (abril 1924), pp. I52-I54].

${ }_{122}$ Muñoz, Orencio: «Giovanni Gentile», Revista de Pedagogía, n. ${ }^{\circ} 7$ (marzo 1924), pp. 96-102 [la cita corresponde a la p. 98]. 
LA PEDAGOGÍA CATÓLICA ITALIANA: ENTRE EL POSITIVISMO
282 Y EL NEOIDEALISMO. NOTAS SOBRE SU PRESENCIA EN ESPAÑA (I87O-I968)
CONRAD VILANOU TORRANO E ISABEL VILAFRANCA MANGUÁN

A pesar de este enfoque humanista, de inspiración gentiliana, la religión no tendría lugar en la educación secundaria (ya que se contaría con la presencia de la filosofía), pero sí en la educación primaria al no poderse incluir en este nivel la enseñanza de la filosofía. De aquí que Orencio Muñoz argumentase lo siguiente, refiriéndose a Gentile: «Sostiene la laicización absoluta de toda la enseñanza, hasta en los internados del Estado, con excepción de la primaria; y no por fanatismo ni cómoda transacción, sino por firme convencimiento sólidamente fundado» ${ }^{123}$. Al comentar la posición del filósofo italiano, Orencio Muñoz pretende situarse a medio camino entre el sectarismo de las izquierdas y el fanatismo intolerante de las derechas. Además, responde a aquel halo de vanguardia y modernidad que desprendían las primeras manifestaciones ideológicas del fascismo que utilizaba un lenguaje de corte espiritual y pseudorrevolucionario. Así se apelaba a la transformación de las conciencias individuales a través de la educación que -contrariamente a lo que había postulado la Ratio jesuítica- fomentaba la libertad del alumno para alcanzar su autoconciencia que, al final, debía fusionarse en la vida del espíritu.

En realidad, en la prensa pedagógica española no solo se publicaban trabajos y recensiones sobre la filosofía de la educación de Gentile, sino también fragmentos de sus obras -por ejemplo, del Sumario de Pedagogía- que se ponían al alcance de los profesionales de la enseñanza. Concretamente, la Revista de Escuelas Normales dio cabida a la versión española «Identidad entre la Filosofía y la Pedagogía», que corresponde al capítulo segundo de la segunda parte del libro primero (Pedagogía General) del Sommario di Pedagogia come scienza filosofi$\mathrm{Ca}^{124}$. La traducción fue realizada por alguien que firmaba bajo las siglas M.B., que probablemente correspondan a Modesto Bargalló. El editor añadía a modo de advertencia preliminar el siguiente comentario, muy esclarecedor: «La Pedagogía de Giovanni Gentile deriva de una Filosofía que ve en el hombre la realidad universal considerada en su actualidad, en la cual es sujeto; de una filosofía que supera el abismo entre la Ética y la Psicología, entre el ser y el debe ser, que da al acto espiritual una totalidad de ambas tendencias» ${ }^{125}$.

Además de la recepción de los textos pedagógicos de Gentile, nuestros pedagogos también viajaron a Italia y dieron cumplida cuenta de sus observaciones. Así, la revista Universidad, editada en Zaragoza, publicó un par de trabajos sobre la cuestión. En esta dirección José Guallart L. de Goicoechea, pensionado por aquella Universidad, informaba sobre «La reforma de la Instrucción pública en Italia», reconociendo que significaba «la reacción ante la mentalidad positivista de la democracia y ante la invasión demagógica en la escuela» ${ }^{126}$. Otrosí,

${ }^{123}$ Ibidem, p. 99.

${ }^{124}$ Gentile, Giovanni: Sommario di Pedagogia come scienza filosófica. I. Pedagogia Generale, Firenze, G. C. Sansoni, editore, 1942, pp. II2-II9.

${ }^{125}$ «Identidad entre la Filosofía y la Pedagogía, según Giovanni Gentile», Revista de Escuelas Normales, I, n. ${ }^{\circ}$ I (enero I923), pp. $25-27$.

${ }^{126}$ Guallart L. De Goicoechea, José: «La reforma de la instrucción pública en Italia», Universidad (Universidad de Zaragoza), II, I (enero-marzo, 1925), pp. I29-I37 [la cita corresponde a la p. 130]. 
LA PEDAGOGÍA CATÓLICA ITALIANA: ENTRE EL POSITIVISMO

Y EL NEOIDEALISMO. NOTAS SOBRE SU PRESENCIA EN ESPAÑA (I870-I968)

CONRAD VILANOU TORRANO E ISABEL VILAFRANCA MANGUÁN

destacaba el fortalecimiento de la cultura greco-latina, introduciendo en todos los niveles, salvo el elemental, el estudio de las humanidades clásicas. También ponía de relieve la importancia de la religión y de la lengua nacional, sin olvidar el arte (música, dibujo), de acuerdo con su posicionamiento idealista que proclama la fusión del arte y de la religión en la filosofía.

Queda claro que los cambios en el gimnasio-liceo -y en general, en la enseñanza media- fueron uno de los aspectos que mayor atención concitó de la reforma italiana que contemplaba una amplia tipología de establecimientos secundarios: escuela complementaria, una especie de bachillerato elemental que combinaba la cultura general con la formación profesional; liceo clásico y liceo científico, que daban el acceso a la Universidad; el instituto técnico, que preparaba para los estudios económicos, industriales y agrícolas; institutos o escuelas de magisterio, y el liceo femenino destinado a la educación de la mujer, pero que no daba acceso a la Universidad ${ }^{127}$. Ante tantas posibilidades, que separaban entre quienes aspiraban a la formación universitaria y aquellos otros orientados al mundo laboral, Gramsci -defensor de la escuela unificada- no dudó en escribir que si se quería romper el elitismo social había que «crear un modelo único de escuela preparatoria (elemental-media) que guíe al jovencito hasta el umbral de la elección profesional, formando entre tanto su capacidad de pensar, de estudiar y de dirigir o de controlar a quienes dirige» ${ }^{128}$.

Por el contrario, aquella reforma de la educación secundaria se dirigió a acentuar el carácter elitista de la educación, lo cual comportó un descenso de alumnos matriculados, una de las pretensiones de Gentile, que debía entender su reforma como una empresa realizada desde arriba, por unos espíritus selectos que pudiesen captar las esencias y sentido de la formación clásica, ya que las humanidades se encontraban presentes en ambos liceos, el clásico y el científico. Mientras tanto, el mundo empresarial no veía con buenos ojos la falta de una orientación práctica que encaminara a los jóvenes bachilleres hacia la industria, una de las exigencias de la racionalidad científico-técnica de aquel momento, que dejaba sentir su influencia en la orientación profesional que había dado lugar a una importante psicología del trabajo sobre todo en Alemania ${ }^{129}$.

Después de una visita realizada por Enrique Herrera Oria -uno de los inspiradores de la reforma educativa del primer franquismo- a dos liceos de Milán y Turín se lamentaba de la escasa acogida que tenían en España las humanidades, cosa que contrastaba con lo que sucedía en Italia: «La lengua latina en el clásico,

${ }_{127}$ Galindo Romeo, Pascual: «Las escuelas intermedias en Italia (Segunda enseñanza, Escuela complementaria, Gimnasio-Liceo, Instituto femenino, etcétera...)», Universidad (Universidad de Zaragoza), III, I (enero-marzo I926), pp. 17-3I.

${ }_{128}$ Gramsci, Antonio: La formación de los intelectuales, México, Grijalbo, 1974, p. I34.

${ }_{129} \quad$ La revista Bibliografía General Española e Hispanoamericana recogía en I94I unos datos extraídos de un artículo del Ministro italiano de Educación, Giuseppe Bottai, publicado en El Libro Italiano. Según esta fuente, durante el período de 1937 a 1940 aparecieron en el país transalpino 3628 títulos dedicados al Derecho, I34I obras de Filosofía, 272I de Historia, cifras que contrastan con las 253r dedicadas únicamente a la Agricultura, Industria y Comercio [Bibliografía General Española e Hispanoamericana, XIII, 4 (junio-agosto I94I), p. 13]. 
LA PEDAGOGÍA CATÓLICA ITALIANA: ENTRE EL POSITIVISMO
284 Y EL NEOIDEALISMO. NOTAS SOBRE SU PRESENCIA EN ESPAÑA (I87O-I968)
CONRAD VILANOU TORRANO E ISABEL VILAFRANCA MANGUÁN

que es el más corriente de Italia, se estudia en los ocho cursos, y en cinco el griego. En los liceos científicos durante cinco también se estudia latín» ${ }^{130}$. A la vista de lo cual, Herrera Oria reclamaba que, por decoro nacional, se habían de crear centros clásicos en España, ante la falta de un bachillerato genuinamente humanista como existía en Italia y que se explica - no cabe duda- por el gusto de los idealistas alemanes (Fichte y Hegel, por ejemplo) por las lenguas clásicas.

No perdamos de vista lo que escribió Fichte en sus Aforismos sobre educación: «Para desarrollar la capacidad del espíritu, nosotros los modernos no tenemos nada más adecuado que el aprendizaje de las lenguas clásicas» ${ }^{131}$. Por su lado, Hegel en el discurso gimnasial de final de curso del 29 de septiembre de 1809 se refería a la importancia de la formación greco-latina con las siguientes palabras: «La plenitud y excelencia de esas obras maestras han de ser el baño espiritual, el bautismo profano, que dé al alma el primer e indispensable tono y color para el refinamiento y la ciencia» ${ }^{132}$. Ideas, en conjunto, bien presentes en el universo pedagógico gentiliano.

Para algunos esta reordenación de la enseñanza media y la Introducción del examen de Estado, que abría las puertas a la enseñanza religiosa, constituían las dos notas de mayor relieve de la reforma Gentile ${ }^{133}$. Tanto es así que los viajes de estudio a la península transalpina fueron una cosa frecuente por aquellos años, tal como confirma María Victoria Jiménez, profesora de Escuela Normal, que en 1924 se desplazó a Italia. A raíz de su periplo, publicó unas «Impresiones pedagógicas de Italia» en diversos números de la Revista de Escuelas Normales durante los años 1925 y 1926. Antes de iniciar su itinerario por tierras italianas, a donde fue a estudiar los liceos femeninos y la situación de las Escuelas de Magisterio, fue recibida en su domicilio particular por Giuseppe Lombardo-Radice, que había ocupado la Dirección de Instrucción Pública cuando Gentile fue ministro, no pudiendo hablar con nadie contrario a la reforma. Dicho esto, se puede añadir que Lombardo-Radice se distanció del fascismo cuando el régimen -después del caso Matteotti- entró en una fase dictatorial, liquidando lo poco que quedaba del antiguo orden liberal.

De aquella conversación, debió surgir el interés de la profesora Jiménez por traducir la obra de Lombardo Radice Accanto ai Maestri. Novi saggi di propaganda pedagogica, editada en 1925, que aquí apareció como La reforma escolar italiana (Junto a los maestros), texto que vertió a nuestra lengua y prologó. Esta es la imagen que nos da María Victoria Jiménez, del que fuera director de instrucción

130 Herrera Oria, Enrique: «Orientaciones de los estudios secundarios en Italia», Razón y Fe, n. 347 (Io de junio de I928), pp. 422-434.

${ }_{131}$ Quintana Cabanas, José María: Pensamiento pedagógico en el idealismo alemán y en Schleiermacher, Madrid, BAC, 20I3, p. 94.

${ }^{132}$ Ibidem, p. 4II.

${ }_{133}$ La aplicación del examen de Estado, la composición y exigencia de los tribunales, las distintas convocatorias, los intereses que se escondían detrás del mismo, constituye un eje transversal del libro de Francisco Morente Valero: «Libro e Moschetto». Política educativa y política de juventud en la Italia fascista (1922-1943), op. cit., pp. 62, 67, 72, 81, etc. 
CONRAD VILANOU TORRANO E ISABEL VILAFRANCA MANGUÁN

pública italiano, una persona apasionada que deseaba que en diez años el diez por ciento de los maestros hubiesen puesto en marcha aquella reforma, ya que sólo podía prosperar si los maestros la hacían vivir: «Tuve ocasión de conocerle en un viaje que hice a Italia hace dos años. Con su aventajada estatura; su cabeza de corte helénico, cuyos ojos se iluminan con todo el fulgor latino; su voz tranquila y serena da una sensación de apóstol de las nuevas ideas para el resurgimiento escolar en Italia» ${ }^{134}$.

En aquel encuentro, Lombardo-Radice comentó que era sabedor de la buena acogida de sus ideas, sobre todo en Cataluña, recibiendo revistas como Butlletí de Mestres y Quaderns d'Estudi que daban noticias de las ideas educativas en boga en Italia. En esta última, por ejemplo, se dio cabida al REsumen de prensa de uno de los parlamentos de Gentile, pronunciado en el otoño de 1923 sobre su reforma educativa. En aquella ocasión, el factótum del neoidealismo destacaba la importancia otorgada a la enseñanza religiosa que había avalado siendo muy consciente que -con ello- estaba dando alas a la escuela laica. Su argumentación se remontaba al setiembre de 1907, cuando, en un congreso nacional de la Federación de la enseñanza media, sostuvo que para que una escuela fuese verdaderamente laica había de ser precisamente religiosa e incluir en las escuelas primarias la enseñanza de la religión católica. Justamente esto es lo que hizo Gentile desde el Ministerio, no observando en tal política ninguna traición a sus ideales: si el Estado es conciencia activa nacional, conciencia del futuro en función del pasado, conciencia histórica, la religión adquiere la categoría de conciencia universal al vivir en el espíritu, debiendo por consiguiente ser revivida y sublimada por un espíritu siempre dispuesto a la crítica y al perfeccionamiento del propio contenido ${ }^{135}$.

En este punto, hay que aludir al curso que Eugenio d'Ors impartió en Barcelona sobre la pedagogía de Gentile durante el año I9I5, si bien no compartía al completo las teorías del que entonces era catedrático de la Universidad de Palermo y que después se instaló en la Escuela Normal de Pisa. En realidad, se trató de un curso monográfico sobre el Sumario de Pedagogía, en el que Xenius remarcó que -siguiendo a Gentile- solo hay una actividad que depende del espíritu porque la verdad vive en el interior del espíritu de manera potencial con lo que la educación se ha de entender como un proceso de autoconciencia ${ }^{136}$.

No está de más recordar que María Victoria Jiménez -en su primer artículo- reproducía unas palabras pronunciadas por Gentile en el Senado italiano, en las que enfatizaba la importancia de la totalidad y su distanciamiento respecto al enciclopedismo, ya que en su opinión no hay tiempo de digerir todo lo que se enseña. «Para ser culto no se precisa conocer algo de todas las ciencias, letras y artes; todos los que estamos aquí en el Senado somos y pasamos por hombres

${ }^{134}$ Lombardo-Radice, Giuseppe: La Reforma escolar italiana, op. cit., p. IX.

${ }^{135}$ «Reproduccions. Un parlament de Giovanni Gentile», Quaderns d'Estudi, n. ${ }^{\circ} 8$ (1924), pp. $65-73$.

${ }_{136}$ Muntaner, Carme: «La pedagogia en els cursos monogràfics d'alts estudis i d'intercanvi. La pedagogia de Giovanni Gentile», Quaderns d'Estudi, any II, vol. I, n. ${ }^{\circ}$ I (octubre I9I6), pp. 25-32. 
cultos y sin embargo cada uno cultiva una dirección del espíritu» ${ }^{137}$. A esta primera entrega, siguieron otras dos en que revisaba la reforma de la educación secundaria, especialmente, en lo tocante a tres puntos: los estudios de magisterio repartidos entre las 89 Escuelas Normales existentes; los tres Institutos superiores (Florencia, Milán, Roma) para la formación de directores e inspectores, y los liceos femeninos, una novedad que era desconocida en España ${ }^{138}$.

Después de publicar estos tres artículos sobre sus impresiones pedagógicas de Italia, María Victoria Jiménez perfiló otro trabajo sobre «La reforma italiana» que incluía unas referencias a las innovaciones introducidas por Gentile, un lugar común en los cenáculos pedagógicos de los años veinte que coincidían con el Directorio Militar en España. Por ello, se veía la reforma italiana con buenos ojos, no solo por la similitud de regímenes políticos, sino también porque los maestros observaban ilusionadamente las reformas italianas iniciadas en 1923. En cuanto al contenido de la reforma, la profesora Jiménez destaca la reIntroducción de la enseñanza religiosa, uno de los aspectos más elogiados por los educadores españoles.

Otra innovación, introducida por Gentile, es el llevar a la escuela el conocimiento directo de las obras maestras de la antigüedad. Así, en vez de manualitos que disecan y caricaturizan la ciencia, el legislador preconiza los grandes autores clásicos y a la vez que Homero, Virgilio y Plutarco, hace reaparecer en la escuela un libro harto olvidado en la escuela italiana anterior que es el Evangelio: Gentile quiere que los niños conozcan el Evangelio y las grandes figuras de la Iglesia Católica, principalmente los Santos italianos no para despertar un sentimiento nacionalista sino nacional, es decir, para que el niño italiano sepa cómo ha contribuido Italia al progreso de la humanidad ${ }^{139}$.

Pues bien, esta idea aparece como la clave de bóveda de la reforma gentiliana, que vio en la religiosidad de las gentes sencillas una prueba de la cultura popular que, a su vez, forma parte del todo del espíritu. Por consiguiente, la escuela debía recuperar la fuente evangélica y, en especial, la narración de la vida de Jesús. Como es fácil deducir, el Antiguo Testamento -aquí podemos recordar las disposiciones raciales de 1938 que provocaron una atroz persecución antisemita, de la que Primo Levi o Natalia Ginzburg son dos ejemplos elegidos un tanto al azarquedaba relegado al priorizar la historia del cristianismo, a partir de Jesús, con la presencia de las bellas historias de los santos italianos. Con todo, sería injusto

${ }^{137}$ JimÉNEZ, María Victoria: «Impresiones pedagógicas de Italia. I. Una entrevista con Lombardo-Radice. II. La reforma del ministro Gentile», Revista de Escuelas Normales, n. ${ }^{\circ} 28-29$ (noviembre I925), pp. 284-285.

${ }_{138}$ JimÉNEZ, María Victoria: «Impresiones pedagógicas de Italia. III. Scuole Magistrali o Escuelas Normales. IV. Regi Istituti Superiori del Magistero», Revista de Escuelas Normales, n. ${ }^{\circ} 30$ (diciembre 1925), pp. 324-325; Jiménez, María Victoria: «Impresiones pedagógicas de Italia. V. Los liceos femeninos», Revista de Escuelas Normales, n. ${ }^{\circ} 33$ (marzo 1926), pp. 324-325.

139 Jiménez, María Victoria: «La reforma italiana», Revista de Escuelas Normales, n. ${ }^{\circ} 55$ (juniosetiembre 1928), p. 223. 
CONRAD VILANOU TORRANO E ISABEL VILAFRANCA MANGUÁN

ver en Gentile un defensor pertinaz del antisemitismo, habida cuenta de que da la impresión de que intentó poner a salvo a más de un profesor o intelectual de ascendencia judía ${ }^{140}$.

Por lo demás, huelga subrayar que el nacionalismo constituye un rasgo característico del fascismo, argumento bien presente en la conferencia que Gentile pronunció el año 1925, en Florencia, sobre Che cosa è il Fascismo. Basándose en Mazzini, Gentile afirmó en aquella ocasión que «una nazione non è un'esistenza naturale, ma una realtà morale». A renglón seguido, añadía: «La nazione sì, veramente, non è geografía e non è storia: è programa, è missione. E perciò è sacrificio». De aquí que la italianidad fuese una característica primordial de la reforma educativa de Gentile. Al decir de Lombardo-Radice los programas escolares constituían el secreto didáctico más importante de la reforma, al estar dirigidos a la conciencia patriótica: «Quieren, sobre todo, que el niño adquiera intimidad con Italia, con su patria; quieren, en la enseñanza de la religión, conocimientos de los santos italianos, de las grandes figuras que viven en las más bellas tradiciones populares... quieren el mayor conocimiento posible de Italia» ${ }^{141}$.

Así las cosas, la reforma Gentile potenció la lengua y la literatura italianas, la historia y la geografía, amén -en los estudios de Magisterio- de «Filosofía y Pedagogía» en detrimento de cuestiones empírico-experimentales, más allá de las tradicionales «ciencias naturales, geografía e higiene». De manera concisa, podemos aseverar que los contenidos de signo espiritualista y nacionalista -expresado según la visión neoidealista- constituían los dos centros neurálgicos de la formación de maestros. Sin embargo, voces como la de Gramsci dudaban de la bondad de la reforma, necesaria pero no bien encaminada. De un lado, se criticaba el empobrecimiento de la enseñanza de la filosofía al extenderse masivamente, quedándose en una bella retórica sin mayor abundamiento. Por otra parte, el reformismo didáctico propugnado por el actualismo gentiliano y sistematizado por Lombardo-Radice tampoco daba sus frutos: «Pero los nuevos programas, cuanto más insisten y teorizan sobre la actividad del discípulo y su esforzada colaboración con el trabajo del maestro, tanto más disponen las cosas como si los alumnos fuesen simples seres pasivos» ${ }^{142}$.

Solo de esta forma se puede entender el interés que despertó la reforma Gentile, cuya filosofía se orquestaba como un canto a la libertad. Las notas sobre esta cuestión proliferaban en la literatura pedagógica de la época, sensibles a las reflexiones de Gentile. Así la Revista de Pedagogía dio cabida a un suelto, titulado «Educación y libertad, según Gentile», firmado por las iniciales M. C. (Margarita Comas, probablemente), en que comentaba un artículo publicado por el pensador italiano en la revista Levana que dirigía Ernesto Codignola, uno de los firmantes en 1925 del Manifiesto de los intelectuales del fascismo, escrito por Gentile y aparecido en la prensa el 2I de abril de aquel año, al que respondió Croce con

${ }^{140}$ Simoncelli, Paolo: «Non credo neanch'io alla razza». Gentile i colleghi ebrei, Firenze, Le Lettere, 20I3.

${ }^{14}$ Lombardo-Radice, Giuseppe: La Reforma escolar italiana, op. cit., 1927, p. 138.

${ }_{142}$ Gramsci, Antonio: La formación de los intelectuales, México, Grijalbo, 1974, p. I29. 
un Contramanifiesto ${ }^{143}$. En esta nota suelta se dibuja, una vez más, el perfil del acto educativo según el esquema neoidealista que otorga al maestro -un tanto socráticamente- el papel de simple acompañante:

El maestro es solo maestro cuando en vez de contraponerse a los alumnos hace que en él vean su propio espíritu, cuando en él ven un alma universal en la cual se resuelve todo dualismo entre la suya y la propia particular individualidad. El maestro ha de salvar, quisiéramos resumir así el pensamiento de Gentile, la humanidad del alumno y al par ha de respetar su individualidad. Esto exige fe en el libre desenvolvimiento del alumno y respeto para con su individual libertad ${ }^{144}$.

Para completar lo que decimos, reproducimos unas palabras extraídas de sus Lecciones de Didáctica y recuerdos de experiencia docentes, que tradujo de la undécima edición italiana Pablo Martínez de Salinas, profesor del Seminario de Pedagogía de la Universidad de Barcelona:

Educación es compenetración de almas, es decir, un estado de conciencia en el cual el maestro desaparece como individualidad distinta de los escolares, y se adapta a su momento espiritual, viviéndolo como suyo y desarrollándolo, para impulsarlo hacia una posición más alta, alcanzada ya por él, independientemente de sus alumnos actuales, en la formación de su propia cultura, posición a la que ha de retornar, reconquistándola con ellos ${ }^{145}$.

La presencia de los protagonistas de la reforma educativa italiana continuó siendo habitual en la prensa pedagógica española. Sin ánimo de ser exhaustivos, lo cual requeriría una empresa más profunda, podemos citar que el año i930, desde las páginas de la Revista de Escuelas Normales, y bajo el epígrafe genérico de «Los clásicos y los modernos de la Pedagogía», se publicaban sendos artículos sobre Lombardo-Radice y Ernesto Codignola, artífices de aquella reforma educativa inspirada en el neoidealismo gentiliano. De mano anónima es el perfil que se traza de Lombardo-Radice, promotor de la «escuela serena» que las hermanas Cossettini desarrollaron a partir de sus intuiciones. Además, se revisaban sus Lezione di Didattica e Ricordi di esperienza magistrale (1912), obra que como

${ }_{143}$ «Manifiesto de los intelectuales del fascismo», en Cassigoli, Armando: Antología del fascismo italiano, México, UNAM, 1976, pp. 166-170. Curiosamente, en este Manifiesto se hacía hincapié en el carácter patriótico y religioso del fascismo, que era presentado entre el Estado liberal y el Estado anhelado por los socialistas, entroncando además con el Risorgimento. A pesar de la retórica, el sentido del texto resulta bien nítido: «Esta Patria es, pues, reconsagración de las tradiciones y de las instituciones, que son la constancia de la civilización en el flujo y en la perennidad de las tradiciones. $\mathrm{Y}$ es escuela de subordinación de aquello que es particular e inferior a aquello que es universal e inmortal. Es respeto a la ley y a la disciplina. Es libertad, pero libertad para conquistarla dentro de la ley que se instaura con la renuncia a todo aquello que es pequeño arbitrio y veleidad irracional y disipadora».

${ }^{144}$ «Educación y libertad, según Gentile», Revista de Pedagogía, n. ${ }^{\circ} 20$ (agosto de 1923), pp. 3IO-3II.

${ }^{145}$ Lombardo-Radice, Giuseppe: Lecciones de Didáctica y recuerdos de experiencia docente, Barcelona, Labor, 1933, p. 2I. 
CONRAD VILANOU TORRANO E ISABEL VILAFRANCA MANGUÁN

hemos indicado se tradujo en I933. Al mismo tiempo, se remarcaba que la acción didáctica conforma un acto de comunión espiritual, de acuerdo con una filosofía de la educación de base neoidealista, que sitúa el papel del maestro como «gran inquietador del espíritu y gran animador del corazón del discípulo» ${ }^{146}$.

Por su parte, Antonio Gil Muñiz se refirió a Ernesto Codignola, director a la sazón del Instituto Superior del Magisterio de Florencia, uno de los tres que existían, destinados a la formación de directores e inspectores bajo las directrices neoidealistas. Se perseguía promover una atmósfera que facilitara la comunión o compenetración espiritual, lo cual implicaba entender la educación como un proceso de vivificación del alumno a través del espíritu, esto es, de la cultura, del arte, de la religión y de la filosofía. Se desdeñaba el pedagogismo, una especie de enfermedad derivada del empirismo psicopedagógico, de modo que se había de centrar la atención en la conciencia de los educandos para que participasen de aquel espíritu global que solo la filosofía podía transmitir. A esta tarea se dedicó Codignola, que también teorizó sobre la historia de la educación, que, junto a la filosofía neoidealista, habían de coadyuvar a la formación de los maestros. «En cuanto a la formación pedagógica, la más honda revolución que en esta disciplina puede hacerse es preparar filosóficamente al futuro maestro. Preparando filosóficamente, los problemas concretamente pedagógicos, adquirirán una solidez, una claridad, y una fundamentación, que en manera alguna puede alcanzar el maestro cuando carece de aquellos estudios» ${ }^{147}$.

Pero hay más, porque el momento álgido de la influencia de la pedagogía de Giovanni Gentile en España se dio con los primeros compases del franquismo, a raíz de la aprobación del plan de bachillerato de i938, de siete años de duración, con presencia del latín en todos los cursos sin olvidar la enseñanza del griego. Además, se incorporó el examen de Estado, siguiendo el modelo italiano. Toda esta fenomenología - detallada con precisión por el profesor Antonio Fco. Canales Serrano- evidencia las concomitancias entre el nacional-catolicismo y el fascismo en la educación secundaria, si bien las diferencias también fueron notorias ${ }^{148}$.

Al poco de producirse el is de abril de i944 la acción partisana, a instancias del Gap (Gruppi d'Azione Patriottica) de inspiración comunista, que causó la muerte de Gentile en las calles de Florencia, Eugenio d'Ors destacaba en una glosa del Novísimo Glosario, titulada «El filósofo asesinado», la importancia que el pensador italiano daba a la unidad entre el acto y la idea, entre el concepto y la expresión, hasta el punto de escribir: «Nunca fue tan grande mi admiración ante la obra de Giovanni Gentile como cuando vi estos principios, idealistas y activistas a la vez, aplicados a una especulación sobre lo pedagógico... que todo es uno, enseñar y aprender». Seguidamente, Xenius añadía lo siguiente:

${ }^{146}$ «El educador italiano G. Lombardo-Radice», Revista de Escuelas Normales, n. ${ }^{\circ} 69$ (enero 1930), pp. 19-24.

${ }_{147}$ Gil MuÑIz, Antonio: «Ernesto Codignola y la reforma italiana», Revista de Escuelas Normales, n. ${ }^{\circ}$ 73-74 (1930), pp. I64-I69 [la cita corresponde a la p. I67].

${ }_{148}$ Canales Serrano, Antonio: «Pemartín y la frustrada fascistización de la enseñanza media española de posguerra», Historia Social, n. ${ }^{\circ} 74$ (2012), pp. 65-84. 
La Cultura no olvidará jamás cómo... un pensador procedente del medio más distante restablecía, primer ministro de Instrucción Pública de Mussolini, la enseñanza religiosa en la escuela italiana. La Italia nueva redimía así las culpas de su ochocientos garibaldino; y el fascio rompía con el Risorgimento, a la misma hora en que el imperio limaba las cadenas de la nación ${ }^{149}$.

Desde aquí se comprende que los esfuerzos del idealismo por la búsqueda de una solución unitaria, que superase la división entre razón teórica y razón práctica, entre pensamiento y acción, encontrasen en Gentile un auténtico valedor, con una solución que disolvía la pedagogía en filosofía. De manera estricta, para el idealismo de Gentile la pedagogía es una disciplina filosófica, potenciando el conocimiento de la historia de la pedagogía y de la filosofía, situación que se tradujo en la circulación de diversos manuales en España (Nicola Abbagnano y Aldo Visalberghi, Dante Morando, Michele Federico Sciacca, Aldo Agazzi, etc.) y Latinoamérica (Ernesto Codignola, Juan Mantovani, etc.), que enfatizaban la importancia de las ideas pedagógicas de cara a la formación de los profesionales de la educación.

Podemos considerar que esta fue una herencia del neoidealismo pedagógico que enfatizó la importancia de la historia de las ideas pedagógicas porque, tal como reconocían Abbagnano y Visalberghi, en el prefacio a su libro (1957) «casi todos los profesores prefieren el método histórico al sistemático, por considerar, fundadamente, que el primero es indispensable para la formación del sentido crítico» ${ }^{150}$. Además, y esto no es menos importante, todos estos autores coincidían en la importancia de lo filosófico para poder entender lo pedagógico, porque -de acuerdo con la tradición neoidealista- los problemas educativos se alumbran a la luz de las cuestiones filosóficas. De ahí, justamente, que Sciacca titulase su libro El problema de la educación en la historia del pensamiento filosófico y pedagógico, que también data de 1957, argumentando que la pedagogía constituye un problema filosófico partiendo del supuesto de que la filosofía es una escuela de libertad (uno de los puntos fuertes del neoidealismo y, por ende, del idealismo de Fichte) y que la educación se entiende como una creación de espiritualidad. El itinerario que se dibujaba, por consiguiente, recuerda la visión de Gentile: de la filosofía a la pedagogía, y de esta a la didáctica.

En las tierras americanas de habla española sobresale el nombre de Juan Mantovani, que el año I93I daba a la imprenta la primera edición de Educación y plenitud bumana, obra reeditada en diversas ocasiones, alcanzando en 1972 la novena edición. Mantovani siempre reclamó una base científico-espiritual para la educación, que ancló en las ciencias de la vida, en el culturalismo histórico y en las ciencias del espíritu. En todo caso, las aportaciones idealistas tampoco quedaron al margen fijando su atención en el idealismo absoluto de Gentile, recordando

${ }^{149}$ D’Ors, Eugenio: Novísimo Glosario (MCMXXXXIV-MCMXXXXV), Madrid, Aguilar, I946, p. II4.

iso Abbagnano, Nicola y Visalberghi, Aldo: Historia de la Pedagogía, México, Fondo de Cultura Económica, 1964, p. 7. 
CONRAD VILANOU TORRANO E ISABEL VILAFRANCA MANGUÁN

que su objetivo último no es otro que «realizar en el hombre la libertad por medio de la libertad» ${ }^{151}$.

Como es fácilmente deducible, los rescoldos del neoidealismo pedagógico -en su versión histórica más que sistemática- dejaron su impronta en nuestro país hasta la llegada de los efluvios del mayo del 68, con sus modas interdisciplinares y su anuncio de la muerte de Pedagogía, según anunció Gilles Ferry desde las páginas de la Éducation Nationale el in de mayo de 1967. Dicho sea de paso, I5 años más tarde -en 1982- este mismo autor precisaba que se trataba de la muerte de la pedagogía dogmática, a la cual contraponía el conjunto pluridisciplinar de las ciencias de la educación.

Antes de concluir este apartado debemos insistir en que la fusión del pensamiento y del acto propuesta por Gentile ponía fin a la escisión entre Psicología y Ética, que se desprendía del modelo herbartiano, de modo que la Filosofía -reducto exclusivo de la Pedagogía, según la visión neoidealista- se perfila desde el horizonte de una unidad que eliminaba la polaridad entre educador y educando, promoviendo el acto educativo desde la perspectiva de la autoeducación, aspecto que sintonizaba con los aires de renovación pedagógica proclives a la actividad del alumno y al fomento de la autoeducación. Por tanto, la autodidáctica de Gentile mereció la atención de nuestros educadores, cosechando desde posiciones católicas -bajo la influencia de Mario Casotti, que en 1930 publicó Maestro e scolaro, saggio di filosofía dell'educazione, obra que ingresó en las bibliotecas de nuestros Seminarios de Pedagogía- más de una crítica hacia una pedagogía que presenta la educación como libre desenvolvimiento del espíritu que siempre es uno ${ }^{152}$.

En consecuencia, la pedagogía de Gentile niega la bipolaridad del proceso educativo, ya que la dualidad del acto educativo -esto es, la relación entre educador y educando- es una apariencia, de modo que potencia el desarrollo libre y autónomo del alumno. Como se ve, nos encontramos ante una concepción dinámica del espíritu que supone la libertad absoluta del educando, quedando circunscrito el papel del maestro a despertar y desarrollar el espíritu del alumno. En una línea que recuerda el De Magistro de san Agustín, el neoidealismo diluye la acción heterónoma sobre el espíritu, porque este se desarrolla como un proceso autocreativo. Al tratar la antinomia fundamental en la educación, centrada en torno al tema de la libertad en la relación entre educando y educador, Gentile escribe en la Riforma dell'educazione las siguientes palabras: "Il maestro, in conclusione, non è fuori, ma dentro, come avvertiva sant'Agostino» ${ }^{153}$. Todo gira, en suma, alrededor de un monismo idealista que presenta el ser humano como un espíritu cognoscente que autónomamente es capaz de acceder al Espíritu universal,

isI Mantovani, Juan: Educación y plenitud humana, Buenos Aires, El Ateneo, 1972, p. I47.

${ }_{152}$ Ros, F. d'A.: «L'autodidàctica segons Gentile», Criterion, X, n. ${ }^{\circ} 36$ (juliol-setembre 1934), pp. 222-229.

${ }_{153}$ Gentile, Giovanni: La riforma dell'educazione. Discorsi ai maestri di Trieste, Firenze, G. C. Sansoni, editore, $1945,4 .^{a}$ ed., p. 47 . Ante esta afirmación, y refiriéndose a la antinomia educandoeducador, Mantovani apostilla en Educación y plenitud humana: «El maestro, en conclusión, no está fuera sino dentro, como advertía San Agustín» (p. 50). 
LA PEDAGOGÍA CATÓLICA ITALIANA: ENTRE EL POSITIVISMO
292 Y EL NEOIDEALISMO. NOTAS SOBRE SU PRESENCIA EN ESPAÑA (I87O-I968)
CONRAD VILANOU TORRANO E ISABEL VILAFRANCA MANGUÁN

desplegándose dinámicamente en un proceso de autoconciencia que pasa por diferentes etapas (arte y religión) antes de fusionarse en la totalidad y unidad de la filosofía, verdadera y única condición de posibilidad de la pedagogía.

\subsection{La reacción católica: política y pedagogía}

Cuando se analiza la reacción católica al estado de cosas que se dieron en Italia después de la Primera Guerra Mundial se observan dos hechos de relieve que tuvieron su incidencia en España. De un lado, nos referimos a la creación el año ı19 del Partido Popular de Luigi Sturzo, que confirma el interés del catolicismo por intervenir en la cuestión política. Por otra parte, tampoco podemos olvidar la fundación de la Universidad Católica de Milán, el r92I, que se convertiría en un referente intelectual y pedagógico para España. Vayamos, empero, por partes y empecemos por señalar que entre nosotros también se confiaba, desde una perspectiva política, en «los principios eternos del Cristianismo, que consagra la gran misión civilizadora de Italia», desmarcándose así del socialismo y del fascismo ${ }^{154}$.

Ya Corpus Barga en sus crónicas desde Italia se hizo eco del espíritu del Partido Popular italiano, fundado en 1919 y liderado por Sturzo, que en 1920 contaba con más de roo diputados en la cámara italiana. «Vimos al partido Popular -escribe Gramsci- conquistar casi cien puestos en los escaños del parlamento, en un bloque donde prevalecían, en lo absoluto, los representantes de la nobleza latifundista, de los grandes propietarios de bosques, de los grandes y medios dueños de fundos y una exigua minoría de los de la población campesina» ${ }^{155}$. En las elecciones de mayo de I92I, en medio de las tensiones económicas de los años de postguerra, el Partido Popular fue la segunda fuerza más votada con Io8 diputados electos, frente a los i2z de los socialistas. El Blocchi Nazionali, que incluía a los fascistas, obtuvo ios escaños ${ }^{156}$. Si entramos en el capítulo de las suposiciones, probablemente una conjunción católico-socialista hubiese podido frenar a los fascistas, que contaron con todo tipo de apoyos, incluso de la Corona y de la Iglesia, que no tuvo inconveniente a desautorizar a Luigi Sturzo ${ }^{157}$.

Mientras tanto, las entrevistas con Filippo Meda -cofundador con Sturzo del Partido Popular- aparecían en la prensa española ${ }^{158}$. En efecto, durante el año 1920 El Sol publicó diversos artículos de Corpus Barga sobre el espíritu del Partido Popular, que a la sazón poseía «2I diarios y 200 semanarios locales; consta de 70 Comités provinciales y de unas 2.600 secciones comunales» ${ }^{159}$. De una entrevista

${ }^{154}$ Ossorio y Gallardo, Ángel: Un libro del Abate Sturzo, Madrid, Estudios Políticos, Sociales y Económicos, 1928, p. 27.

iss Gramsci, Antonio: La formación de los intelectuales, op. cit., p. 47.

${ }_{156}$ SAssoon, Donald: Mussolini y el ascenso del fascismo, Barcelona, Crítica, 2008, pp. II6-II7.

157 BetTonicA, Luis: La marcha sobre Roma, Barcelona, Bruguera, 1977, especialmente pp. 89IOI.

${ }_{158}$ BARGA, Corpus: Viajes por Italia, op. cit., pp. I02-IO6.

159 Ibidem, p. 156. 
LA PEDAGOGÍA CATÓLICA ITALIANA: ENTRE EL POSITIVISMO

Y EL NEOIDEALISMO. NOTAS SOBRE SU PRESENCIA EN ESPAÑA (I870-I968)

CONRAD VILANOU TORRANO E ISABEL VILAFRANCA MANGUÁN

mantenida por este periodista, entresacamos las siguientes declaraciones del cofundador del Partido Popular:

El Partido Popular se diferencia esencialmente del Partido Socialista en la importancia que da a la función espiritual en la sociedad. La solución de más apremio y de más fundamento para nosotros es la del espíritu, es decir, la de la escuela. Pedimos la libertad de enseñanza y el examen de Estado. Que el Estado no monopolice la enseñanza. Libre concurrencia, presidida oficialmente por un examen. Las Universidades del Partido Popular serán católicas, y con ellas pensamos triunfar ${ }^{160}$.

Con relación a la influencia de Sturzo en España, descuella el nombre de Ángel Ossorio, que en 1928 presentó un REsUmen de la obra Italia y el fascismo, aparecida en 1927, siguiendo el camino iniciado por Cambó, que también se interesó por la política italiana ${ }^{161}$. En ella se recogía la reflexión del sacerdote italiano sobre la Italia del Risorgimento que cometió un grave error en plantearlo todo desde la perspectiva del «espíritu del Piamonte y el modelo de Francia, copiando de ésta cuanto había heredado de la Monarquía absoluta, de la Revolución y del Imperio, y olvidando las notas diferenciales que Italia, por su disgregación histórica, tenía como característica imprescindible» ${ }^{162}$. Además, Ángel Ossorio recordaba que Sturzo acertó al fundar el Partido Popular, teniendo empeño en no llamarle partido católico, "porque la religión no debe ser un criterio de división política, sobre todo en un país como Italia, donde la mayoría de la población es católica» ${ }^{163}$. Con lo que decimos, queda confirmado el deseo de instalar en España un partido político que respondiese a los esquemas de la Democracia Cristiana, según el modelo del Partido Popular de Luigi Sturzo, que se vio obligado a exiliarse durante el fascismo.

Desde un prisma pedagógico, el catolicismo italiano no podía sentirse cómodo con ninguna de las dos opciones pedagógicas que hemos comentado, es decir, el positivismo que dominó el panorama educativo durante el siglo xIX y el neoidealismo, gestado desde los comienzos del siglo xx a través de la filosofía de Gentile, y que adquirió rango de ley oficial a partir de la reforma de i923. De alguna manera, la filosofía perenne siempre se ha presentado -solo basta recordar la posición de la neoescolástica que Mercier promovió desde la Universidad de Lovainacomo una síntesis, que se opone a los excesos y, por ende, a la negación metafísica del positivismo, siempre proclive al materialismo e, igualmente, a la disolución de la libertad individual en el todo del espíritu filosófico que se manifiesta en el Estado. Por su lado, Agostino Gemelli dejó patente la postura católica respecto al idealismo, en el discurso inaugural de la Universidad Católica del Sacro Cuore, fundada al final de la etapa liberal (I92I), correspondiente al año académico I930-3I.

${ }^{160}$ Ibidem, p. 159 .

161 CAмBÓ, Francisco: En torno del fascismo italiano: meditaciones y comentarios sobre problemas de politica contemporánea, prólogo de Ángel Ossorio y Gallardo, Barcelona, Editorial Catalana, 1925 .

162 Ossorio y Gallardo, Ángel: Un libro del Abate Sturzo, op. cit., pp. II-I2.

${ }_{163}$ Ibidem, p. 29. 
En línea con la tradición lovainense y los trabajos de la Universidad Católica de Friburgo (Suiza), cuya fundación se aprobó el año I886, censura las posiciones de Croce y Gentile. Al primero lo acusa de ser daltónico en lo que se refiere al sentido religioso, mientras que a Gentile después de reconocerle algunos méritos - «Il Gentile, come Ministro della Pubblica Istruzione, ha per noi cattolici alcune benemerenze che non possiamo dimenticare»- también acepta que posee una alma religiosa, si bien el papel de la Iglesia queda asumido por el Estado.

De igual forma, el catolicismo se opone al idealismo actualista que al postular la unidad impide la distinción entre hombre y Dios, entre natural y sobrenatural, entre materia y espíritu, entre ser y deber ser, entre pensar y actuar. «Noi -escribe Gemelli-, combattendo l'Idealismo, vogliano fare opera del più puro, del più ideale morale della patria, dell'Italia nostra, l'Italia di Dante, di Tomaso D’Aquino, di Alessandro Manzoni» ${ }^{164}$. En vista de lo que antecede, se vislumbran las dos caras de una Italia escindida no solo por cuestiones religiosas -entre católicos y laicistas-, sino también ideológicas entre demócratas y fascistas. En fin, estas dos imágenes de Italia son las que colisionaron a partir de la substitución de Mussolini por Badoglio, el 25 de julio de 1943, cuando el país cisalpino vivió una profunda guerra civil que perduró hasta 1945 , aunque los actos de violencia se prolongaron incluso después de la firma de la paz $z^{165}$.

Por tanto, Gemelli -que fue visitado por Enrique Herrera Oria en su despacho, retratándolo como un «hombre de constitución hercúlea, todo iniciativa»- pretende romper la ecuación entre idealismo e italianidad, sin nombrar al fascismo, por el cual también mostró alguna simpatía inicialmente. Con el paso del tiempo, la Universidad Católica de Milán adquirió la condición de referente para España, hasta el punto de que Enrique Herrera Oria apunta sobre el particular: «No desesperamos que en España surja una Universidad Católica al estilo de la del Sagrado Corazón de Milán» ${ }^{166}$. Recordemos las palabras de Gemelli: «La Religión se estudia y se vive en la Universidad del Sagrado Corazón, como se estudia y se vive la vida nacional ${ }^{167}$.

En cualquier caso, Gemelli presenta el idealismo como una cosa extranjerizante, lo mismo que sucedía con el positivismo masónico. «Dunque l’Idealismo non ha operato per lo sviluppo del pensiero italiano; anzi, al contrario, ha operato un riassorbimento nel pensiero italiano di elementi eterogenei e stranieri» ${ }^{168}$. De alguna manera, la escolástica -en tanto que procedente de Tomás de Aquinosí que se perfila como algo genuinamente italiano, inspirando a la Universidad

${ }_{164}$ Gemelli, Agostino: «L'Università Cattolica e l'Idealismo», en Idee e battaglie per la coltura cattolica, Milano, Vita e Pensiero, 1933, p. 466.

${ }_{165}$ En España los sectores falangistas se hicieron eco de este episodio con la traducción del libro de Giorgio PIsano: Sangre llama sangre, Barcelona, Ediciones Acervo, 1964.

${ }_{166}$ Herrera Oria, Enrique: «La Universidad Católica de Milán», Razón y Fe, n. ${ }^{\circ} 363$ (1929), pp. 406-416 [la cita corresponde a la p. 416].

${ }_{167}$ Gemelli, Agustín: España e Italia en la defensa de la civilización cristiana contra el bolchevismo, traducción y prólogo de Isidoro Martín, Ávila, Librería Religiosa, 1938, p. 29.

${ }_{168}$ Gemelli, Agostino: «L'Università Cattolica e l'Idealismo», en Idee e battaglie per la coltura cattolica, op. cit., p. 467 . 
CONRAD VILANOU TORRANO E ISABEL VILAFRANCA MANGUÁN

Católica de Milán, inaugurada el 7 de diciembre de I92I, cuando el Partido Popular se encontraba en una posición ascendente. Además, después de la firma de los Pactos de Letrán de 1929, Gemelli arguye que el catolicismo es la religión del Estado, «perciò vogliamo serviré la nostra patria facendo sì che in essa si viva quella vita cristiana che garantisce agli individui e alla società il vero benessere nel raggiungimento del fine ultimo della vita umana» ${ }^{169}$.

Sirvan estos antecedentes para ilustrar las críticas de Emilio Chiocchetti -representante del neotomismo milanés- al idealismo gentiliano, censuras que también llegaron a España, donde los intelectuales católicos se hicieron eco -por ejemplo, Josep María Capdevila- de las ideas expuestas en el libro La Filosofía de Giovanni Gentile, publicado por la Universidad Católica de Milán (Vita e pensiero) en $1925^{170}$. La presentación de este libro - una decidida crítica al neoidealismo- pone de manifiesto que los católicos españoles -o, como mínimo, algunas de sus élites intelectuales- eran sabedores de los peligros que se cernían sobre los jóvenes educandos, a partir del reconocimiento de que la religión formaba una de las esferas de la realidad del espíritu que es una actividad continua e infinita, posición que choca con el pensamiento católico que limita el espíritu situándolo bajo el imperio de la ley divina. Además, al ser la actividad espiritual humana infinita e indeterminada -por responder a la libre autoconciencia del yo- no se precisa de ningún fin teleológico. Por otra parte, al coincidir el pensamiento y la cosa pensada según el neoidealismo no existe diferencia ontológica entre los entes, despareciendo la diferencia entre hombre y Dios, entre lo finito y lo infinito, entre la criatura humana y el Ipsum Esse Subsistens.

En vista de lo expuesto, la Pedagogía católica en Italia se presenta como un elemento a medio camino entre ambos polos, es decir, entre el positivismo paidológico y el neoidealismo filosófico, si bien -como reconoció Mario Casotti en el Congreso Internacional de Pedagogía de Santander de I949- «la pedagogía católica, que, en Italia, durante el siglo XIX, había tenido grandes y grandísimos representantes que van desde Rosmini a Lambruschini y a San Juan Bosco, estaba un poco adormecida a principios del siglo XX» ${ }^{171}$. Ahora bien, y tal como recuerda el mismo Casotti -instalado en la Universidad Católica de Milán, donde la expresión «Vita e pensiero», título de la revista iniciada en I9I4, se ha convertido en una especie de lema que suplanta el de «Pensiero e azione» de Mazzini-, fue Gentile, junto al cual se formó, quien se preocupó por publicar por vez primera, en lengua italiana, los dos De Magistro, el de san Agustín y el de santo Tomás. Ahora bien, lo que en realidad sucedió fue que Mario Casotti mantuvo una estricta obediencia a la pedagogía neoidealista, participando activamente en la revista Levana que dirigía Codignola, hasta el año I924, cuando experimentó una conversión que le llevó al catolicismo y al tomismo. Curiosamente, las obras de

${ }^{169}$ Ibidem, p. 470.

170 Capdevila, Josep M.a: «La filosofia di Giovanni Gentile, per Emili Ghiocchetti», Quaderns d'Estudi, XV, n. ${ }^{\circ}$ 54, pp. 3I-38 y n. ${ }^{\circ} 55$, pp. I02-107.

${ }^{171}$ CasotTi, Mario: «Problemas y direcciones generales de la pedagogía en Italia», Revista Española de Pedagogía, VII, n. ${ }^{\circ} 27$ (julio-septiembre 1949), p. 469. 
LA PEDAGOGÍA CATÓLICA ITALIANA: ENTRE EL POSITIVISMO
296 Y EL NEOIDEALISMO. NOTAS SOBRE SU PRESENCIA EN ESPAÑA (I87O-I968)
CONRAD VILANOU TORRANO E ISABEL VILAFRANCA MANGUÁN

Casotti -correspondientes a su etapa neoidealista- tuvieron una cierta acogida en la España de los años veinte ${ }^{172}$. Pero lo cierto es que, a pesar de ello, sus libros no encontraron aquí editores ni traductores, tampoco después de su tránsito al catolicismo militante.

De todas formas, Casotti distinguía, dentro de las filas católicas, dos grupos importantes, a saber, los defensores del tomismo y los partidarios del agustinianismo, lo cual garantizaba la existencia de los representantes de la escolástica milanesa (réplica de la lovainense, si bien según Sciacca acentuaba su dogmatismo) y los seguidores del espiritualismo cristiano que, como mínimo en España, recoge partidarios de la tradición idealista gentiliana. Seguidamente reproducimos las palabras de Sciacca, en que se muestra crítico con la tradición neoescolástica italiana: «Pero el centro del Neotomismo italiano contemporáneo ha sido (y sigue siendo) la Università Cattolica de Milán, que presenta una característica peculiar con respecto a la de Lovaina. En el fondo, defiende un tomismo intransigente y ajeno a cualquier concepción en el campo de la metafísica» ${ }^{173}$. Sea como fuere, lo cierto es que Joseph Ratzinger -el papa Benedicto XVI- no dudó en pronunciar un discurso en ocasión del nonagésimo aniversario de la fundación de la Universidad de Milán, una «feliz intuición del padre Agostino Gemelli» ${ }^{174}$.

Junto a estas dos corrientes -la escolástica-tomista y la espiritualista-agustiniana- se vislumbran otras dos más: una materialista, que circula por la izquierda hegeliana y posee connotaciones marxistas (Labriola, Gramsci), que llegaría a España a partir de 1968, y otra experimentalista que -sin caer en los excesos del positivismo- no está reñida con la vertiente escolástica y que a nivel continental ofrece nombres de prestigio como Raymond Buyse y Émile Planchard, ambos formados en Lovaina. Después de todo, la pedagogía neoescolástica no denigra los aportes de la pedagogía experimental, si bien se niega a reducir la pedagogía a simple experimentación, tal como proponía Lay. Además, junto al experimento, siempre habrá que dar cabida a la experiencia, a la práctica, esto es, a aquello que hace que la pedagogía sea la ciencia y el arte de la educación, en una línea de actuación que recuerda la posición herbartiana que insistió en el carácter dual ciencia y arte- de la educación, destacando la importancia del tacto pedagógico, que puede equipararse a la prudencia aristotélica.

En verdad, la cuestión empírico-experimental no tuvo un fácil encaje en la pedagogía italiana, en que siempre hubo resistencias ante el peligro de identificar la pedagogía experimental con la antigua pedagogía positiva. Si el neoidealismo cerraba la puerta a la experimentación, la pedagogía neoescolástica ponía límites

${ }_{172}$ La profesora María Victoria Jiménez, que seguía de cerca los acontecimientos pedagógicos italianos, dio noticia del libro de Casotti La nueva Pedagogia e i compiti dell'educazione moderna [Revista de Escuelas Normales, n. ${ }^{\circ}$ 12, (febrero 1924), pp. 58-59].

${ }_{773}$ Sciacca, Michele Federico: Filosofía, hoy. De los orígenes románticos de la filosofía contemporánea hasta los problemas actuales, op. cit., p. 427.

${ }^{174}$ «Discurso a la Universidad del Sacro Cuore con motivo del $90^{\circ}$ aniversario de su fundación, 2I de mayo de 20II», en Siete discursos universitarios de Benedicto XVI, Madrid, Fundación Universitaria Española, 20II, pp. I69-177. 
CONRAD VILANOU TORRANO E ISABEL VILAFRANCA MANGUÁN

para no ahogar la dimensión filosófica -esto es, la praxis moral- y el sentido experiencial, distinguiendo la acción didáctica del experimento. Con independencia de esta cuestión, Casotti abogaba, poco después de la Segunda Guerra Mundial, por una pedagogía perenne que, por un lado, acentuaba la dimensión ético-teleológica abierta a la trascendencia y, por otro, aceptaba las observaciones del trabajo experimental, cosa lógica si tenemos en cuenta el apego que la neoescolástica de Lovaina tuvo por el trabajo del laboratorio que importó de Alemania. Esta síntesis encuentra una espléndida caja de resonancia en la Universidad Católica del Sacro Cuore de Milán, erigida por Benedicto XV, el día de Navidad de I920, e inaugurada a fines del año siguiente, ocupando el rectorado Agostino Gemelli, de la orden franciscana, quien abrió un Laboratorio de Psicología Experimental, que pronto se convirtió en un referente continental.

\section{Tres referentes pedagógicos católicos}

\section{I. Don Bosco, el carisma salesiano}

De entrada, hay que hacer una declaración previa a fin de sopesar la influencia de san Francisco de Sales (1623-1662), desencadenante del carisma salesiano, que había sido alumno de los jesuitas y obispo de Ginebra. Su Introducción a la vida devota (1608) ha circulado profusamente, contabilizándose numerosísimas ediciones. En el fondo bibliográfico de la Universidad de Barcelona se localizan ediciones correspondientes a los años 1675, 1747, 1759, 1762, 1791, 1808, 1844 y 1931. Es solo un ejemplo de su larga longevidad y actualidad que se avivó durante los años veinte del siglo pasado, como una respuesta del catolicismo a la situación de crisis generalizada que siguió a la Gran Guerra. En realidad, la Introducción a la vida devota reúne un amplio abanico de orientaciones prácticas para regular la vida cristiana: la amistad, el vestido, el lenguaje, los pasatiempos, las recreaciones, los bailes, el juego, la danza, etc. De hecho, se trata de una síntesis -a medio camino entre lo profano y lo sagrado; a caballo siempre de la cortesía y de la piedad- extraída de un conjunto de cartas y tratados que san Francisco de Sales había escrito para Luisa de Duchatel, esposa de su primo Claudio de Charmoysi.

Aunque nos encontramos ante una obra de comienzos del siglo XvII, que rezuma un aire humanista que combina el optimismo y el moralismo, se trata de un manual que exhorta a una vida de perfección cristiana sin renunciar a la cultura profana y espiritual. «Saint François de Sales est un gentilhomme et un homme du monde» ${ }^{175}$. Esta afirmación se puede completar con otras consideraciones de tomo similar: san Francisco de Sales asume el ideal de «l'honnête homme», que más tarde definiría Pascal, cristianizándolo hasta convertirlo en una especie de gentleman católico. Por ello, traza un plan ideal que apunta hacia Dios, en medio de una sociedad mundana,

${ }_{175}$ Vincent, Francis: Saint François de Sales. Directeur d'âmes. L'éducation de la volonté, Paris, Gabriel Beauchesne, éditeur, 1926, p. I5. 
llegándose a elaborar -como hizo Balmes- unas máximas para cada día del año. Por ejemplo, las correspondientes a los días 5, 6 y 7 de junio -días en que se celebra el presente evento- dicen lo siguiente. Para el día 5: «Basta recibir los males cuando vengan, sin que hayamos de prevenirlos con un desmesurado temor, afligiéndonos ya por adelantado». Para el siguiente día, 6 de junio, reza así: «Cuando se dice que nos hemos de despojar de nosotros mismos, se entiende para revestirnos en seguida de Jesucristo crucificado». Como sea que la clausura del Congreso tendrá lugar el día 7, nos permitimos reproducir la máxima correspondiente a esta fecha: «No digáis nunca: Fulano es un vicioso, aunque sepáis que haya caído una vez en algún vicio; pues que un solo acto no basta para formar un hábito».

Si san Francisco de Sales tuvo que enfrentarse a un ambiente jansenista y calvinista, atemperando su rigorismo y aceptando, por ejemplo, el juego de acuerdo con la virtud de la eutrapelia, san Juan Bosco abordó las secuelas que generaba una incipiente sociedad industrial en aquel Turín industrial donde fundó en I847 el Oratorio de San Francisco de Sales. Con el paso del tiempo, la Congregación Salesiana fue aprobada en 1864 y reconocida en 1874 , no sin dificultades. Esta realidad hizo que ejerciese una influencia notable en España, siendo Don Bosco invitado a visitar la ciudad de Barcelona, donde moró unas semanas durante el mes de abril de I886, bajo la protección de familias adineradas y piadosas como Dorotea Chopitea y de Villota (I8I6-I89I), que sería la gran benefactora de las escuelas profesionales salesianas de Sarriá ${ }^{176}$. Los lazos entre Don Bosco y la Ciudad Condal llegaron a ser tan fluidos que el historiador Ramón Alberdi no dudó en rotular uno de sus libros con este título inequívoco: Una ciudad para un santo (1966), escrito cuando se cumplían 8o años de la visita de Don Bosco ${ }^{177}$. Es bien sabido, además, que la construcción del templo dedicado al Sagrado Corazón, que corona la montaña del Tibidabo - uno de los dos templos expiatorios de la ciudad de Barcelona-, surgió a partir de una sugerencia del santo italiano.

No vamos a descubrir a estas alturas el carisma pedagógico salesiano, pero sí que debemos detallar -siquiera brevemente- tres de sus aspectos más destacados: su carácter preventivo; su dimensión lúdica -una pedagogía de la alegría-, que coincide con el posicionamiento de san Francisco de Sales respecto a la vida, y, naturalmente, su apego por el trabajo desde la perspectiva de la formación técnico-profesional. Dicho con otras palabras: Don Bosco se convierte en un auténtico pedagogo social, de recia cepa católica y popular, cuya acción se hace amable a los ojos de todos los públicos, creyentes y librepensadores, obreros y capitalistas, pobres y ricos. De ahí su éxito, que se canaliza no solo a través de la red de escuelas y talleres salesianos, dedicados a favorecer la infancia obrera y desvalida, sino también su ejemplo, que se convirtió en un referente para la juventud española. Tanto es así que la vida del santo -beatificado en 1929 y canonizado

${ }^{176}$ Alberdi, Ramón: Dorotea de Chopitea y de Villota, I816-I891: construir una Barcelona para todos, Barcelona, Edebé, 2009.

${ }_{177}$ Alberdi, Ramón: Una ciudad para un santo: los orígenes de la obra salesiana en Barcelona, en el 150 aniversario del nacimiento de San Juan Bosco y el 80 de su visita a la ciudad condal: 1886I966, Barcelona, Tibidabo, 1966. 
CONRAD VILANOU TORRANO E ISABEL VILAFRANCA MANGUÁN

en 1934, durante la época de conciliación entre el Estado italiano y la Iglesiaadquiere connotaciones ejemplares. En esta dirección, el Juanito de Parravicini tuvo su correspondiente versión salesiana en la obra homónima que presentaba la infancia y adolescencia del "padre de los niños», librito estructurado en I2 capítulos, que concluía con un «Sacerdote!!! Siempre entre niños» que describía -entre otros aspectos- a su madre Margarita, su vocación religiosa y los aspectos más representativos de la sociedad salesiana ${ }^{178}$. Además de este Juanito, Juan Cassano escribió unos Hechos memorables de la vida de San Juan Bosco, obras que se reimprimían constantemente, en muchas ocasiones sin indicación de año, ya fuese en las escuelas profesionales salesianas de Barcelona o Pamplona. Hay que añadir que la vida de Don Bosco también fue divulgada fuera de los círculos salesianos, y así editorial Bruguera publicó en 1958 la biografía de Giuseppe della Roca, abundantemente ilustrada, con destino a niños y adolescentes.

El hecho de que los salesianos dispusiesen de importantes talleres-imprenta facilitó que se editaran libros y colecciones a favor de la educación de los jóvenes. Así, a título de ejemplo, citamos la Biblioteca de Lecturas de la Librería Salesiana, que responde a la «misión heredada de nuestro santo padre el Vble. Bosco, una de cuyas mayores preocupaciones fue, sin duda alguna, el proveer abundantemente libros honestos y agradables para saciar con ellos la natural sed de lectura que sentía -y más que nunca ahora la siente- la juventud de sus días». Aquella Biblioteca de Lecturas ofrecía diversas líneas o directrices: Primeros siglos del Cristianismo, Misiones Católicas entre infieles y Hazañas de jovencitos héroes. Los autores eran padres de la Pía Sociedad Salesiana, destacando el nombre de Ricardo de Beobide, creador de muchas obras, unas sobre Don Bosco -aquí anotamos la Vida popular de Don Bosco, que llegó como mínimo a la novena edición, o la Vida brevísima del Vble. Juan Bosco: Resumen de rasgos biográficos- y de una serie de lecturas para adolescentes, con innumerables títulos (La vestal mártir, El cuadro misterioso, Bautizado en su sangre, Lirio silvestre, El amor en el odio, La conjuración de Katikiro, El verdugo de su bijo, ;Redimidos!, El bijo del gobernador, etc.). La dimensión eutrapélica de la pedagogía salesiana hizo que se publicasen también obras para el solaz recreo de la juventud y así constatamos la existencia de una galería Dramática Salesiana, a manera de comedias, bufonadas y textos similares.

Al lado de Ricardo de Beobide, cabe mencionar al novelista argentino Gustavo Adolfo Martínez Zuviría (I883-I962), intelectual católico que ocupó diversos cargos de confianza política en una época un tanto convulsa de la historia de aquella nación sudamericana. Aquí nos interesa destacar que con el seudónimo de Hugo Wast pergeñó diversas obras sobre la vida de san Juan Bosco y la llegada de los salesianos a América. Así, por ejemplo, circularon por España-después de la Guerra Civil- sus obras más representativas en este ámbito, jalonado por títulos como Juanito Bosco, Las aventuras de Don Bosco en dos volúmenes (Burgos, Ediciones

${ }_{178}$ Cassano, Juan: Juanito. Infancia y adolescencia del «Padre de los niños», traducción del italiano por Manuel Almazán, Pamplona, Escuelas Profesionales Salesianas, 2. ${ }^{a}$ ed., sin fecha. 
Aldecoa, 1945-1959) y Su segunda patria. Aventuras del Padre Vespignani, sobre la historia de los salesianos en la Argentina y su labor misional en la Patagonia.

De tal guisa que Don Bosco representa el prototipo de educador de la juventud, con lo que su figura adquiere la connotación de verdadero pedagogo social en el mundo católico. En los años de postguerra Rodolfo Fierro se encargó de realizar un estudio sistemático sobre la pedagogía social de Don Bosco, así como una biografía detallada suya ${ }^{179}$. Con el paso del tiempo, la pedagogía salesiana abandonó un tanto la dimensión apologética de primera hora -que el nacionalcatolicismo propició- para sistematizarse a través de una obra sólida que en su proceso de institucionalización cuenta, además, con la ayuda del Pontificio Ateneo Salesiano, fundado en I94I, que dio lugar a la Universidad Pontifica Salesiana y la casa editorial LAS, que tiene su réplica en España (Edebé). Mientras tanto aparecía en 1954 la revista Orientamenti Pedagogici, dependiente de la Facultad de Ciencias de la Educación de la Universidad Salesiana de Roma ${ }^{180}$.

Si bien superamos el límite de 1968 que nos hemos marcado, podemos añadir que, entre los autores recientes vinculados a la causa salesiana que han llegado a España, destacan los nombres de Pietro Braido (La experiencia pedagógica de Don Bosco, LAS, 1989) y Carlo Nanni, que, junto a José Manuel Prellezo, participó en el Dizionario di scienze dell'educazione (Torino, 1997). Además, Nanni ha intentado dar respuesta al sentido pedagógico después de la llegada de la crisis postmoderna con su libro sobre L'Educazione tra crisi e ricerca senso: una approccio filosofico (LAS, I990).

Por tanto, podemos concluir que la pedagogía salesiana se ha consolidado en los últimos tiempos desde la doble perspectiva histórica y sistemática. En efecto, diversos autores -destacamos los nombres de Ramón Alberdi, José Manuel Prellezo García (Educar con Don Bosco: ensayos de pedagogía salesiana, 1997) y Pietro Braido- han profundizado en la dimensión histórica del carisma salesiano. Así, mientras Alberdi se ha dedicado a rastrear los vestigios salesianos en la ciudad de Barcelona, Prellezo se encargó de la edición de las actas del Congreso Internacional de Estudios sobre San Juan Bosco, celebrado en la Universidad Pontificia Salesiana, en Roma, del 16 al 20 de enero de i989, en el que participaron diversos estudiosos españoles ${ }^{181}$. Poco después, en el 2000 , destacaba el papel de Valdocco en el siglo XIX, entre lo real y lo ideal: documentos y testimonios sobre una experiencia pedagógica. Por su lado, Pietro Braido ha abordado la figura de Don Bosco desde la perspectiva de su servicio a la idea de Humanidad (Don Bosco nella Chiesa a servicio dell'umanità, LAS, 1987), sin olvidar la Esperienze di pedagogia cristina nella storia (LAS, I99I).

${ }_{179}$ Fierro Torres, Rodolfo: La pedagogía social de Don Bosco, Madrid, CSIC, I949; Fierro Torres, Rodolfo: Biografía y escritos de San Juan Bosco, Madrid, Editorial Católica, 1955.

${ }_{180}$ Groppo, Giuseppe: Teologia dell'Educazione. Origine, identità, compiti, Roma, LAS, I99I, especialmente pp. 88 y siguientes.

${ }^{181}$ Don Bosco en la historia: actas del Primer Congreso Internacional de Estudios sobre San Juan Bosco, edición de José Manuel Prellezo García, Roma, LAS/Madrid, CCS, 1990. 
CONRAD VILANOU TORRANO E ISABEL VILAFRANCA MANGUÁN

En lo tocante a la cuestión sistemática se ha producido una relectura actualizada de la pedagogía salesiana con análisis del sistema preventivo (Braido, I964), la edición de las Obras Fundamentales del Santo fundador, con un estudio introductorio de Pietro Braido (BAC, 1978), a la que siguió una teoría de la educación bajo el título de $E d u c a r$ (Sígueme, 1982, 2. ${ }^{a}$ ed.). A la vista de estos autores y títulos, resulta fácil destacar que la presencia de la pedagogía salesiana se extiende desde hace más de un siglo, manteniéndose vivo el carisma de Don Bosco, estudiado históricamente y sistemáticamente, releyéndose de acuerdo con los signos de los tiempos, en una tarea hermenéutica que parte de la atención a los más desatendidos y que, tradicionalmente, ha fomentado la formación profesional, un viejo tema pendiente que no fue abordado debidamente en la Italia del Risorgimento, ni tampoco en la España contemporánea hasta época reciente.

\subsection{Gemelli y la tradición psicopedagógica neoescolástica}

Si la neoescolástica fue una empresa dinamizada por el cardenal Mercier desde la Universidad de Lovaina, a fines del siglo XIX, su Introducción y consolidación en Italia viene de la mano del médico y filósofo Agostino Gemelli (1878-1959), el fundador de la Universidad Católica de Milán (1921), que había cursado la carrera de Medicina y completado sus estudios filosóficos en Lovaina (1911). A su regreso de Bélgica, publicó un libro donde denunciaba las falsificaciones de Ernesto Haeckel (1912), con lo cual combatía al positivismo, doctrina con la que había flirteado durante sus años de formación. Durante la Gran Guerra, actuó como capellán militar en el Cuartel General del Ejército, alcanzando el grado de coronel, siendo influido por la obra de Oswaldo Külpe, que fomentó la introspección experimental.

Algunos biógrafos señalan que Gemelli era un médico materialista y socialista en sus años mozos, pero gracias al influjo de Contardo Ferrini -especialista en Derecho- volvió al seno de la Iglesia ingresando en la orden franciscana. Podemos añadir que Ferrini, nacido en 1859, murió el 17 de octubre de 1902, después de que el día 22 de setiembre hiciese una excursión a la montaña, con lo cual se convirtió en un referente para los jóvenes católicos, muchos de los cuales militaban en el movimiento de la Acción Católica. Según señaló Agostino Gemelli, Contardo Ferrini -terciario franciscano enterrado en la capilla de la Universidad Católica de Milán- simboliza la fusión de la santidad personal y el rigor del estudio, aspectos que promovieron su beatificación el año 1947. Con ocasión de aquel evento, la Universidad Católica publicó diversos volúmenes en su honor, algunos de cuyos títulos llegaron a España ${ }^{182}$. Y aunque la figura de Contardo

${ }_{182}$ Portaluppi, Angelo: El alma religiosa de Contardo Ferrini 1859-1909, prólogo del P. Agostino Gemelli, traducción de José Miquel Macaya, Vic, Editorial Sala, 1947 [el título del libro indica estas fechas, aunque Ferrini murió en 1902]. También el 1947 apareció el libro de T. Domínguez del Río: Beato Contardo Ferrini. Glosas al margen de su vida. Lumbres y estímulos para la juventud, Madrid, Editorial Coculsa. 


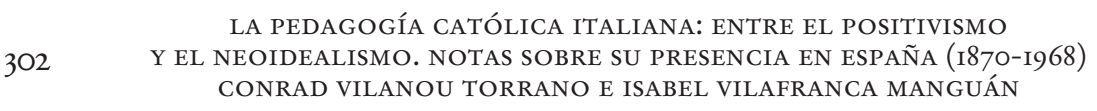

Ferrini no pasó desapercibida, está claro que aquí el discípulo -Agostino Gemelli- supera con creces la proyección intelectual y significación pedagógica de su maestro Ferrini.

De alguna manera, en el universo mental de Gemelli -que sigue el esquema aristotélico-tomista, esto es, de la neoescolástica, desde la cual combatió las ideas de Freud-se parte de los datos empíricos sin olvidar la dimensión metafísica, es decir, trascendente del ser humano en una síntesis elaborada según los principios de la filosofía perenne. Gemelli, pues, se dedicó a los estudios psicólogos, publicando diversas obras que circularon en España, si bien sobresalió en el campo de la orientación profesional. Antes de la Guerra Civil participó en las diversas conferencias internacionales de Psicotecnia, algunas de las cuales tuvieron lugar en España. Se adhirió a la causa franquista (participó por ejemplo en la revista Escorial) ${ }^{183}$, siendo acusado de haber desencadenado la leyenda negra que cayó sobre Emilio Mira y López. Al parecer, el inicio de la Guerra Civil impidió que Gemelli asistiese a la Universidad Católica de Santander que estaba prevista para el verano de 1936.

En cualquier caso, sus obras psicológicas circularon en España, por ejemplo, sus manuales: Orientaciones de la Psicología experimental (Barcelona, Subirana, 1927), su Introducción a la psicología (elaborado juntamente con G. Zunini en

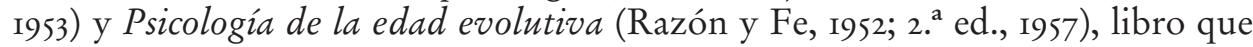
al decir de los especialistas constituye su obra de mayor enjundia ${ }^{184}$. Igual importancia posee, desde un punto de vista pedagógico, La orientación profesional

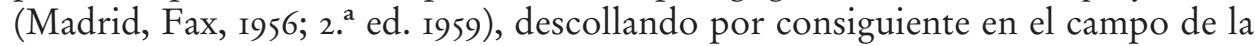
psicotecnia ${ }^{185}$. De hecho, ya había publicado en Italia trabajos sobre la psicotecnia aplicada a la industria analizando el papel del obrero en la industria moderna, sin olvidar la psicología de guerra. Por ello, sus obras examinan los métodos y las directrices de la psicotecnia industrial, partiendo de una doble base: I) constatación de la importancia que el factor humano tiene en el trabajo industrial; 2) daño que ocasiona el maquinismo en la actividad humana. Por tanto, podríamos añadir que Gemelli defiende una posición humanista ya que critica la tendencia a la selección en detrimento de la conveniente y adecuada orientación, en consonancia con la Doctrina Social de la Iglesia. Es evidente, además, que su obra polifacética ofrece otras caras y perspectivas que se escapan a los objetivos de este trabajo, como por ejemplo su idea de Universidad.

En realidad, y junto al nombre de Gemelli, hay que ponderar la aportación de Mario Casotti, responsable de la pedagogía en la Universidad Católica de Milán, donde enseñó entre 1924 y 1964. Aunque se formó en el círculo próximo a Gentile, su obra se dirige a combatir el neoidealismo a través de la neoescolástica,

${ }_{183}$ Gemelli, Agustín: «Biología y psicología», Escorial, i2 (1943), pp. 3II-340.

${ }_{184}$ Moragas, Jerónimo de: «La figura paradigmática de Agostino Gemelli», Perspectivas Pedagógicas, n. ${ }^{\circ} 4$ (1959), pp. 404-406; Masino, V.: «El P. Gemelli, apóstol de la cultura católica», Augustinus, IV (1959), pp. 543-546.

${ }^{185}$ Gemelli, Agustín: «El problema de los salarios en el cuaderno de la psicotecnia», Revista Internacional de Sociologia, n. ${ }^{\circ}$ I9 (1947), pp. 33-48; n. ${ }^{\circ}$ 20, pp. 329-344. 
CONRAD VILANOU TORRANO E ISABEL VILAFRANCA MANGUÁN

restaurada con la encíclica Aeterni Patris (I879) de León XIII y cultivada en Lovaina por el Instituto Superior de Filosofía que dirigía el cardenal Mercier. En Lovaina se aspiraba a una síntesis entre lo nuevo y lo viejo, según la fórmula Nova et Vetera, que apareció en la cabecera de la Revue Néo-Scolastique fundada en I894 a modo de portavoz del Institut Supérieur de Philosophie (1889). Por su parte, Gemelli promovía publicaciones como la Rivista di Filosofia Neoscolastica (I909) y Vita e pensiero (I9I4), desde cuyas páginas autores como Casotti desgranaban su ideario, a la vez que presentaban, desde una perspectiva sintética, la pedagogía como la ciencia y el arte de la educación.

También esta visión sintético-unitaria se da en la psicología de Gemelli, que ve el ser humano como una realidad psicobiológica, que puede ser estudiada por métodos introspectivos y experimentales, en un planteamiento de base realista que conecta con la tradición de la filosofía neoescolástica. De alguna manera los inicios de la psicología en España no pueden deslindarse de sus aportaciones, como bien demuestran las relaciones que mantuvo con el jesuita Fernando María Palmés, que dirigía el Laboratorio de Psicología que los jesuitas tenían establecido en Barcelona, mucho antes del inicio de la Guerra Civil.

Bien mirado, la neoescolástica ha defendido la viabilidad de la pedagogía como ciencia sintética, que reúne y sistematiza los datos que suministran las diversas disciplinas, con lo cual no acepta la epistemología de las ciencias de la educación que acaban por eliminar -al ser innecesaria- la presencia de la ciencia pedagógica. Se trata, además, de una síntesis conceptual ya que se parte de la noción de persona que se caracteriza por la doble dimensión natural y sobrenatural, lo cual implica una puerta abierta a la metafísica. Es obvio que la pedagogía neoescolástica prepara el personalismo pedagógico, si bien hay que recalcar la importancia de la tendencia a la síntesis -o, si se quiere, a la unidad científica y filosófica- como uno de sus rasgos más característicos. De cara a nuestros intereses, podemos añadir que, si el neoidealismo redujo la pedagogía a filosofía, en un proceso de simplificación que pretendía superar la separación herbartiana entre psicología y ética, entre el positivismo mecanicista y la teleología pedagógica, la neoescolástica se abrió a todas las disciplinas, reservando un lugar específico para la pedagogía que se distingue por ser un saber de síntesis o unitario, evitando caer en los excesos de la pedagogía experimental (Lay, Meumann) y del deber-ser del Estado-ético del neoidealismo fascista (Gentile) e, incluso, del sociologismo (Durkheim, Natorp).

Además, la neoescolástica encontraba un punto de apoyo en la filosofía de Tomás de Aquino y, por ende, en su filosofía de la educación resumida en $D e$ Magistro. Al igual que Gentile, Casotti también procedió a la traducción de las obras dedicadas a ennoblecer la figura pedagógica del maestro, ya sea en línea agustiniana como tomista. Si el neoidealismo lo reducía casi todo al activismo del alumno, la filosofía neoescolástica enfatiza el papel del maestro como causa eficiente y ejemplar del proceso educativo. Ahora bien, conviene recordar que al situarse en un justo término medio la pedagogía neoescolástica tampoco desdeña la autoeducación, que en el campo católico destacó Romano Guardini -de 

LA PEDAGOGÍA CATÓLICA ITALIANA: ENTRE EL POSITIVISMO
304
Y EL NEOIDEALISMO. NOTAS SOBRE SU PRESENCIA EN ESPAÑA (I87O-I968)
CONRAD VILANOU TORRANO E ISABEL VILAFRANCA MANGUÁN

nacionalidad alemana, aunque de origen familiar italiano- con sus Cartas sobre la formación de sí mismo, un clásico de la pedagogía contemporánea.

Llegados a este punto, podemos traer a colación que la neoescolástica italiana vinculó la génesis de su pensamiento a la propia historia nacional, representada ahora por el Aquinate, en contra de los extranjerismos que representaban el positivismo y el idealismo. Bien se comprende que esta vuelta a la Edad Media puede entenderse como una decidida respuesta a una serie de corrientes de pensamiento que emergieron en el siglo XIX (criticismo, positivismo, evolucionismo, agnosticismo, etc.) y que, en conjunto, exaltaban el «culto a la ciencia», quebrando con su pasión analítica la siempre necesaria síntesis general. De ahí, pues, que Casotti presente la pedagogía como una ciencia práctico-poiética, de ascendencia aristotélica, cristianizada por el tomismo, reformulada a la luz de la neoescolástica, lo cual reclama una síntesis entre los diversos conocimientos que ha de dominar el educador, sobre la base que la pedagogía es el arte y la ciencia de la educación ${ }^{186}$.

A pesar de habernos visitado en alguna ocasión, la circulación de las obras de Mario Casotti -autor de un volumen sobre el Il pensiero pedagogico di Padre Gemelli (196I)- fue un tanto menor. Cuando a comienzos de los años cincuenta el profesor Juan Tusquets topó con su Educazione Cattolica (3. ${ }^{a}$ ed., 1950) deploró no haber conocido hasta entonces «esta obra que descuella en la valiosa y extensa producción de Casotti y le sitúa entre los pedagogos católicos de primera categoría».

Sin embargo, no pasó lo mismo con Aldo Agazzi, uno de sus discípulos más predilectos. Además de su conocida Historia de la filosofía y de la pedagogía, reeditada en varias ocasiones (I971, 2. ${ }^{a}$ ed.; I974-I980, 3. ${ }^{a}$ ed.), llegaron hasta aquí sus manuales sobre la Psicología del niño (1967, 5. ed.) y su Pedagogía, didáctica, preparación para del maestro: preliminares introductorios (1982). Sintomáticamente, Agazzi incardinó -buscando siempre la síntesis unitaria- los aportes de la psicología pedagógica con la historia de la tradición pedagógica, ausente en el esquema herbartiano, si bien Otto Willamn ya la tuvo en cuenta. No por azar, el Laboratorio o Instituto de Psicología fue uno de los motores de la Universidad Católica de Milán. Justamente la historia también está presente en la pedagogía de Piero Viotto, llamado por Aldo Agazzi para enseñar Pedagogía en el Instituto Superior de Educación Física de la Universidad Católica de Milán. Cabe destacar, por un lado, sus aportaciones históricas sobre Don Bosco y Maritain e, igualmente, su historia antológica de la educación física en Italia (1983).

Si la presencia de la pedagogía salesiana ofrece una constante en España, no ocurre lo mismo con la neoescolástica italiana. Empezó con fuerza a través del publicismo arborescente de Gemelli que durante décadas, entre i925 y 1955, aparece en muchos espacios y lugares. En el debate ideológico, en el campo de la educación social, en los estudios psicológicos, en el terreno de la orientación profesional, en la discusión de la idea de Universidad, en el terreno médico y

186 Galli, Norberto: «La "Pedagogia» e le “scienze dell'educazione»», Pedagogia e Vita, 3 (1997), pp. 22-56. 
CONRAD VILANOU TORRANO E ISABEL VILAFRANCA MANGUÁN

sacerdotal, en las cuestiones y problemáticas del trabajo, en el pensamiento pedagógico, en el estudio de la criminología, en lo tocante a la psicología de guerra, etc., pero sus epígonos -sobre todo Casotti- dejaron una huella bastante débil y volátil, rectificada en parte por Aldo Agazzi y Piero Viotto. ¿Qué sucedió para que fuera así? Nos aventuramos a sugerir que la presencia de la escuela lovainense en España fue significativa desde fines del siglo XIX, de modo que autores como Zaragüeta -un filósofo-pedagogo formado a la sombra de Mercier- indicó que el camino prioritario a seguir estaba en Bélgica y no en la Lombardía, aunque las revistas católicas españolas acogían las noticias sobre ambos centros de enseñanza superior ${ }^{187}$. Sin pretender entrar en cuestiones políticas, podemos añadir que el papel de Mercier -su dignidad ante el ocupante alemán durante la Primera Guerra Mundial- resultaba más atractivo que el de Agostino Gemelli, que abogó por la intervención de las tropas italianas en la Guerra Civil. Este detalle quizá fuese menor, pero lo cierto es que a partir de 1960 los nombres de la pedagogía neoescolástica italiana van difuminándose, por más que su producción es firme y continuada.

\subsection{Del neoidealismo al espiritualismo personalista}

Se ha dicho anteriormente que ciertos autores detectan en la obra de Gentile antiguas resonancias cristianas. Esto quiere decir que algunos de los puntos del actualismo neoidealista recuerdan la pedagogía agustiniana, con lo cual se impuso la tarea de rectificar al neoidealismo. En consecuencia, había de depurarlo de su carga inmanente que cercena la dimensión metafísica, lo cual obligaba a volver a las fuentes del espiritualismo cristiano de raíz agustiniana. De la misma manera que se hablado de un neoidealismo se podría aceptar la existencia de un neoespiritualismo que tuvo en el pensamiento de Michele Federico Sciacca (1908-1975) a su mejor representante, si bien la cosa venía de antiguo ya que se vinculaba al espiritualismo del Risorgimento, sobre todo de Antonio Rosmini, Armando Carlini y Augusto Guzzo. En cualquier caso, M. F. Sciacca dedicó al filósofo neoidealista sus Estudios sobre Filosofía Moderna, publicados en España en I966, con la siguiente leyenda: «A Giovanni Gentile, maestro de filosofía, con la profunda devoción de ayer, de hoy y de siempre».

Si reparamos en todos estos nombres -Carlini, Guzzo, Gentile, Sciacca- aparece una línea de continuidad o, si se quiere, un cierto aire de familia que en España también despertaba interés ${ }^{188}$. Veamos seguidamente lo que escribía Manuel Gonzalo Casas en el prólogo al libro La existencia de Dios de Sciacca:

${ }^{187}$ Así, en las páginas de Razón y Fe, después de publicar el artículo de Enrique Herrera Oria sobre «La Universidad Católica de Milán [n. ${ }^{\circ} 363$ (I929), pp. 406-416], se daba noticia de «La Universidad Católica de Lovaina» [n. ${ }^{\circ} 428$ (1932), pp. 5-17].

${ }_{188}$ Uscatescu, George: «Filosofía italiana contemporánea: Armando Carlini», Revista de Filosofía, n. ${ }^{\circ}$ I6 (1957), pp. 303-320. 
LA PEDAGOGÍA CATÓLICA ITALIANA: ENTRE EL POSITIVISMO
306 Y EL NEOIDEALISMO. NOTAS SOBRE SU PRESENCIA EN ESPAÑA (I87O-I968)
CONRAD VILANOU TORRANO E ISABEL VILAFRANCA MANGUÁN

Por eso en cada espiritualista, sea Carlini, Guzo, Sciacca, queda una actitud radical como herencia del idealismo gentiliano: primero, la primacía absoluta de los actos espirituales, de la autoconciencia en cuanto fundamento del pensar; segundo, el sentido crítico como activa disponibilidad de la inteligencia, que no se somete a instancias o supuestos dados. Lo primero explica la reducción metodológica de la realidad a la vida del espíritu y, lo segundo, la búsqueda infatigable de la filosofía como saber realizador de la ontología humana ${ }^{189}$.

En cierto sentido, y debido a la dinámica de los acontecimientos políticos, los espiritualistas italianos no acababan de encontrarse cómodos con el idealismo de Gentile, cosa que se acentuó después de la Segunda Guerra Mundial. Sciacca escribió en 1948 su libro sobre san Agustín, donde confiesa su evolución intelectual que se inició en 1936 con un estudio sobre las líneas del espiritualismo crítico, reflejando el paso de un idealismo trascendental o subjetivo -y que él denomina espurio- al trascendental, realista u objetivo ${ }^{190}$. Su misión no es otra que depurar el espíritu del idealismo actualista, para volver a las fuentes platónicas y agustinianas, y así destaca el papel de la interioridad. No se trata, empero, de una interioridad subjetiva inmanente, sino de una interioridad transcendente que encuentra en el pensamiento de san Agustín -autor revisitado frecuentemente, sobre todo en aquellos años- un referente. No hay que perder de vista que, sobre la base de la interioridad, el ser humano puede descubrir -a través de la intuición- la existencia de una luz eterna o divina, esto es, Dios ${ }^{191}$.

No es la razón (el sujeto o una de sus actividades) la que es universal, sino la luz de la verdad que ella recibe de la inteligencia: la universalidad pertenece al objeto, a la Idea, hace que la razón sea capaz de un conocimiento verdadero sin identificarse con una verdad o con la verdad racional en general, la cual es un segundo conocer, porque el saber primero es la intuición del ser como Idea. La razón, respecto a la inteligencia, es una actividad subordinada; la discursividad es inferior a la intuición. En efecto, Dios no es razón, sino Inteligencia, Espíritu ${ }^{192}$.

Como es fácilmente observable, de la tradición neoidealista surgió una filosofía espiritualista que halló una espléndida caja de resonancia en la prolífica obra de Sciacca, integrada por más de cuarenta volúmenes publicados por la editorial Marzorati, muchos de los cuales fueron traducidos por la editorial Luis Miracle. Nos encontramos, pues, ante una filosofía espiritualista que es profundamente

189 Sciacca, Michele Federico: La existencia de Dios, prólogo de Manuel Gonzalo Casas, Buenos Aires-Tucumán, Editorial Richardet, 1950, pp. 7-8.

${ }_{190}$ La aparición del San Agustín de Sciacca coincidió con el de Przywara, de modo que Ramiro Flórez estableció un paralelismo entre ambos en «El estudio de San Agustín. Dos libros actuales», La Ciudad de Dios, vol. CLXII, pp. 371-388. Este retorno a san Agustín se puede completar con el que escribió Papini y al que hemos aludido al comienzo de este trabajo.

191 Flórez, Ramiro: «Recuerdo español de M. F. Sciacca», Revista Agustiniana de Espiritualidad, XVI, n. ${ }^{\circ}$ 49-50 (1975), pp. I63-169.

${ }_{192}$ Sciacca, Michele Federico: La interioridad objetiva, Barcelona, Luis Miracle, 1963, 2. ${ }^{\text {e ed., }}$ pp. 46-47. 
CONRAD VILANOU TORRANO E ISABEL VILAFRANCA MANGUÁN

cristiana y que se distancia del inmanentismo gentiliano, que concibe el espíritu al modo hegeliano. En consecuencia, se defiende un humanismo espiritualista de raíz cristiana, de significación teocéntrica, en que el hombre se relaciona con Dios desde el interior de su conciencia.

Por consiguiente, en lugar de hablar de neoidealismo debemos referirnos al espiritualismo italiano contemporáneo, según el libro de S. Alderghi, Metafisica e spiritualisti italiani contemporani (Milano, Marorati Editore, 1960). Se mantiene la dimensión idealista, mas no subjetiva, sino transcendental y objetiva de la tradición platónica y cristiana. Naturalmente, en este esquema san Agustín ocupa un lugar preferente, de modo que la revisión o relectura de su pensamiento constituirá una pieza clave para esta corriente pedagógica, genuinamente filosófica como la gentiliana, que remarca la importancia de los clásicos como unidad del estudio de la filosofía.

El desarrollo del pensamiento es "orgánico»; siendo en sus comienzos casi embrional, gradualmente va tomando forma, sangre y nervios con la primera intuición, con el estado poético y con la riqueza que va asimilando, hasta hacerse principio unitario de un sistema. El estudio de los clásicos es el conocimiento del organismo viviente constitutivo del pensamiento, es decir, de nuestra humana grandeza ${ }^{193}$.

Nos hallamos ante un planteamiento orgánico-espiritual según el cual la tarea de educar se entiende como un proceso de vivificación, de crecimiento personal, desde la conciencia interior del yo personal -iluminado por la luz divina- y que se canaliza a través del conocimiento histórico del pensamiento. En cierto sentido se repite el esquema epistemológico de Gentile al señalar que la pedagogía depende de la filosofía (esto es, del pensamiento) y no compartir el criterio del didactismo que lo centra todo en el proceso de la adquisición de conocimientos. En efecto, la pedagogía es mucho más que una técnica didáctica, porque «educar es un acto moral y por esto es lo opuesto de la técnica, de lo útil y de lo económico; $\mathrm{y}$, si es acto moral, su objeto inalienable es la persona humana en su consistencia de espíritu, del que todo lo mundano es medio para su perfeccionamiento» ${ }^{194}$.

Sciacca enfatiza el sentido etimológico de educar como "sacar fuera», de educere, de modo que educar es, ante todo, «un acto de interioridad, es inclinar al hombre a que lea dentro de sí». Así se plantea una línea pedagógica de signo socrático, vivificada por la tradición cristiana (san Agustín, Pascal), con lo que este educar como «sacar fuera» implica toda una operación de autoconocimiento, de reflexión sobre uno mismo, manteniendo - de acuerdo con la tradición neoidealista- la fundamentación filosófica de la pedagogía.

Educar es sacar desde dentro, es decir, habituar a ver dentro de nosotros; a escucharnos, porque dentro del corazón de los hombres está presente la verdad, que

${ }_{193}$ Sciacca, Michele Federico: El problema de la educación en la historia del pensamiento filosófico y pedagógico, op. cit., p. 38.

${ }^{194}$ Ibidem, p. 40. 
LA PEDAGOGÍA CATÓLICA ITALIANA: ENTRE EL POSITIVISMO
308 Y EL NEOIDEALISMO. NOTAS SOBRE SU PRESENCIA EN ESPAÑA (I87O-I968)
CONRAD VILANOU TORRANO E ISABEL VILAFRANCA MANGUÁN

en él habla. Educar es, por tanto, lo mismo que filosofar, especular; y el filosofar es ya, como tal, educación de la buena, de la que sólo pertenece al hombre, de la que consiste en ser acto de sacar fuera la verdad, que marca a nuestra alma y es de ella el pan de vida, fecundo en frutos de nueva vida ${ }^{195}$.

Queda claro, pues, que la influencia de Sciacca -con su ideario pedagógicodejó su impronta en España, apareciendo a su muerte algunos números monográficos dedicados a ensalzar su figura ${ }^{196}$. Esta presencia confirmaba la viabilidad de una línea agustiniana que convivía con la tomista, de modo que la neoescolástica milanesa y el agustinianismo italiano formaban un doble pilar de la pedagogía católica italiana que, en algunos casos, caminaba hacia la síntesis al integrarse -en una sola dirección- el pensamiento de san Agustín y santo Tomás. Este aire espiritual-agustiniano -que en muchos casos procedía del neoidealismo- aparece en el panorama pedagógico, tal como retrató el profesor Gonzalo Jover en su documentado análisis de la filosofía de la educación en Italia ${ }^{197}$. En aquella ocasión, distinguía tres grandes corrientes: la del personalismo pedagógico cristiano, la pedagogía laica y progresista y la marxista. En el interior del primer grupo, y junto al núcleo de la Universidad Católica de Milán capitaneado por Casotti, destacaba la presencia del grupo Scholé, que en los años de postguerra ejerció notable influencia. De hecho, la cosa empezó al poco de concluir la contienda con el movimiento filosófico de Gallarate, ciudad del Norte de Italia, en la zona de Varese, cuya primera reunión tuvo lugar en el mes de octubre de $1945^{198}$.

Justamente el movimiento filosófico de Gallarate revisó la cuestión pedagógica en su décima reunión, correspondiente al año I954, a la que acudieron -entre otros- los profesores Calò, Flores d'Arcais, Stefanini, Agazzi, Catalfamo, que en líneas generales pueden vincularse al personalismo ${ }^{199}$. En última instancia, aquella novena reunión de 1954 -celebrada los días 6, 7 y 8 de setiembre en el "Aloisianum» de Gallarate- buscaba estrechar de nuevo los lazos de la educación con las ideas metafísicas. El nombre de «Alosianum» remite al jesuita San Luis Gonzaga, además de cobijar al Instituto universitario de estudios filosóficos de los hijos de San Ignacio.

El grupo Scholé organizó diversas asambleas pedagógicas a partir de 1954 en las que participaban -junto a los profesores italianos (Flores d'Arcais, Aldo Agazzi, Calò, etc.)- autores españoles como Víctor García Hoz y Adolfo Muñoz-Alonso. Este último -director de la revista Crisis, desde cuyas páginas se dio noticia de

${ }^{195}$ Ibidem, p. 4I.

${ }_{196}$ Destacamos los publicados por la revista Folia Humanistica en el mes de septiembre de 1968 y la revista Crisis en el número 58, correspondiente al período abril-diciembre del mismo año.

${ }_{197}$ Jover Olmeda, Gonzalo: «La filosofía de la educación en Italia: tendencias en la segunda mitad del siglo xx y perspectivas actuales», en La filosofía de la educación en Europa, op. cit., pp. I6I-179.

${ }_{198}$ Muñoz-Alonso, Adolfo: «El movimiento filosófico de Gallarate», Augustinus, II (1957), pp. $77-87$.

${ }_{199}$ Giacon, Carlo: «O Problema Pedagogico. Relaçao da X Reuniao de Gallarate», Revista Portuguesa de Filosofía, n. ${ }^{\circ}$ I2 (1956), pp. 163-180. 
LA PEDAGOGÍA CATÓLICA ITALIANA: ENTRE EL POSITIVISMO

Y EL NEOIDEALISMO. NOTAS SOBRE SU PRESENCIA EN ESPAÑA (I870-I968)

CONRAD VILANOU TORRANO E ISABEL VILAFRANCA MANGUÁN

las asambleas pedagógicas de Scholé-200 fue el que mayor sintonía demostró con este espiritualismo italiano de cepa agustiniana y que, remotamente, dependía del neoidealismo. En último término, se pretendía salvaguardar la dimensión filosófica de la pedagogía, sin caer en los excesos de Gentile, pero orillando también las pretensiones del positivismo que ahora -bajo la fórmula de la pedagogía experimental- volvía a surgir con fuerza. Adolfo Muñoz-Alonso -uno de los mejores representantes de esta corriente en España- escribía en 1957: «Por eso quizá quepa afirmar que la experimentación es un capítulo, todo lo importante que se quiera, de la ciencia pedagógica, pero sin poder constituir ciencia autónoma» ${ }^{201}$. De hecho, y de acuerdo con la doctrina agustiniana, solo se aprende cuando se $\mathrm{da}$ invención por parte del alumno -un sujeto espiritual- ya que todo radica en una interioridad que dialécticamente se conecta con el exterior y que remite a algo superior y transcendente, es decir, a Dios. «Pero el hombre, como sujeto de experiencia, es un concepto y una realidad mucho más amplia y fecunda que la posibilidad de experimentación, como ha mostrado Flores d'Arcais y ha ilustrado sabiamente el profesor Agazzi» ${ }^{202}$.

De acuerdo con lo que decimos, la filosofía se convertía de nuevo en la fuente de la pedagogía e, incluso, de la didáctica, con lo que a estas alturas -a comienzos de la década de los sesenta del siglo pasado- se mantenía el pulso respecto al positivismo. Adolfo Muñoz-Alonso recordaba que «sólo el positivismo puede desarrollar una concepción didáctica al margen de la Filosofía» ${ }^{203}$. En resumidas cuentas, esta tendencia espiritualista de raíz agustiniana postulaba una teoría de la formación humana que considera al ser humano en su dimensión radicalmente espiritual, con lo que el acto didáctico afecta al núcleo más íntimo e interior del educando, lo que supone que el Maestro es más un educador que un vulgar instructor. Se postulaba, pues, una pedagogía profundamente humanista y cristiana, enraizada en el pensamiento clásico (Platón y Aristóteles) y cristiano (san Agustín y santo Tomás).

A estas alturas, el influjo del neoidealismo había quedado del todo olvidado. La presencia del pensamiento de Sciacca, con una teoría educativa bien explícita y sistematizada, y los ecos del movimiento filosófico de Gallarate y las asambleas del movimiento Scholé hicieron el resto. Mientras tanto, Adolfo Muñoz-Alonso -un tanto desde la soledad- abogaba por esta pedagogía profundamente espiritualista que pretendía establecer de nuevo un puente entre ambas penínsulas, entre Italia y España. Resulta lógico, pues, que Aldo Agazzi -catedrático de la Universidad Católica del Sacro Cuore de Milán- prologase la versión italiana del libro de Muñoz-Alonso Il Magisterio come forma di vita, cuya traducción

\footnotetext{
200 «II Asamblea Internacional de Pedagogía de «Scholé»», Crisis, n. ${ }^{\circ} 9$ (I956), pp. II3-II6; «La experimentación en Pedagogía en la III Asamblea de «Scholé»», Crisis, n. ${ }^{\circ}$ I2 (1956), pp. 58I-585.

${ }_{201}$ Muñoz-Alonso, Adolfo: «El carácter científico de la experimentación en Pedagogía», Crisis, I3 (enero-marzo 1957), pp. 67-69 [la cita corresponde a la p. 68].

${ }_{202}$ Ibidem, p. 69.

${ }^{203}$ Muñoz-Alonso, Adolfo: «La Filosofía como fuente de la Didáctica», Augustinus, V (1960), pp. 65-73 [la cita corresponde a la p. 66].
} 
también corrió entre nosotros. Al fin y a la postre, este espiritualismo quedaba puesto al servicio de un personalismo de raíz cristiana. «La educación tiene como fin y campo de acción la formación de la personalidad del educando como persona, dotado, por tanto, de una originalidad singular» ${ }^{204}$.

\section{A manera de conclusión}

A lo largo de estas páginas hemos intentado abordar, desde un planteamiento inspirado en la historia del pensamiento pedagógico, las relaciones educativas que se han establecido entre España e Italia, desde el Risorgimento hasta poco después de la Segunda Guerra Mundial. Hemos procurado atender de manera prioritaria a la recepción de las grandes ideas o intuiciones pedagógicas (positivismo y neoidealismo, principalmente), a la vez que hemos enfatizado la importancia del peso de la educación católica que -en consonancia con la posición de la pedagogía perenne- se sitúa en medio de ambas corrientes, esto es, del positivismo y del neoidealismo.

Es cierto que a partir de 1870 -con la instauración de un Saboya en el trono de España- Italia adquiere cierto relieve y presencia en la historia española, si bien las cosas venían de etapas anteriores, desde el inicio del Risorgimento. Fue entonces cuando el catolicismo liberal italiano (Rosmini especialmente) dejó sus huellas en aquella España que vivió una crisis similar a la experimentada por Italia en el cambio del siglo XIX al xx. Naturalmente que la reacción al positivismo constituye un fenómeno un tanto paralelo, aunque la aportación del neoidealismo -con su carga neohegeliana- es algo genuinamente italiano que mereció la atención de los educadores españoles que siguieron de cerca la reforma Gentile. Mientras el neoidealismo italiano tuvo una clara manifestación pedagógica, sobre todo durante el fascismo, en España quedó un tanto diluido por diversos motivos (por la oposición del catolicismo, por la breve pero innovadora experiencia de la Segunda República, etc.), aunque en verdad fue observada llegando -en más de una ocasión- a ser públicamente elogiada.

Con este telón de fondo, la pedagogía católica italiana también incidió en nuestros ambientes educativos, distinguiéndose tres grandes líneas: la pedagogía salesiana, la neoescolástica milanesa y la vertiente espiritual personalista. En este orden de cosas, la pedagogía salesiana constituye una línea sostenida desde primera hora, desde aquella visita de Don Bosco en I886 a España. No sucede lo mismo -siendo más intermitente- la incidencia de la neoescolástica que tuvo en Agostino Gemelli un inequívoco punto de referencia durante la primera mitad del siglo pasado. La neoescolástica milanesa ha mantenido un cierto tono, pero ha tenido que competir con la influencia que procedía directamente de Lovaina. En todo caso, se constata igualmente la presencia de los vientos espiritualistas

${ }^{204}$ Agazzi, Aldo: «Itinerario pedagógico de Muñoz-Alonso», Augustinus, VII (1962), pp. 165I74 [la cita corresponde a la p. 167]. 
CONRAD VILANOU TORRANO E ISABEL VILAFRANCA MANGUÁN

que siguieron a la debacle del neoidealismo gentiliano que propició la aparición de un espiritualismo personalista que rechazaba la inmanencia del actualismo pedagógico de Gentile. En efecto, durante la etapa que siguió a 1945, sobre todo en las décadas de los años cincuenta y sesenta, el espiritualismo de clara vocación cristiana -que encuentra un excelente valedor en el pensamiento de Michele Federico Sciacca- suplantó al neoidealismo, de modo que la pedagogía italiana mantuvo durante décadas un sesgo predominantemente filosófico bien visible en los manuales de historia de la educación que llegaban desde Italia. Insistimos que este abandono del neoidealismo favoreció la emergencia del espiritualismo personalista, estableciéndose puentes de intercambio y diálogo que hoy se han consolidado a través de una serie de revistas -Rassegna di Pedagogia, Pedagogia e Vita, Orientamenti Pedagogici, I Problemi della Pedagogia, etc.- que, aunque con dificultades por las modas anglosajonas, también llegan a los anaqueles de nuestras hemerotecas, sin olvidar el peso de editoriales de orientación cristiana -La Scuola Editrice de Brescia, LAS, Vita e Pensiero, etc.- que lanzan libros que no siempre son traducidos a nuestra lengua.

En fin, es obvio que en un trabajo de las presentes características no podemos dar cuenta y razón de todas y cada de las iniciativas católicas (Lorenzo Milani sería un buen ejemplo) que han influido desde Italia, que se encuentra muy cerca de España geográfica y culturalmente pero que, desde un punto de vista factual, se halla mucho más lejos. Por lo general, los españoles nos hemos sentido atraídos por las luces del Norte que venían de Francia, Alemania e Inglaterra, quedando Italia un tanto rezagada en la hora de las predilecciones. Quizá uno de los frutos positivos de las presentes Conversaciones salmantinas sea acortar las distancias, aplanar los caminos y favorecer el intercambio de ideas en una Europa que, a menudo, parece que haya olvidado los valores del espiritualismo humanista de la tradición cristiana, una auténtica vía pedagógica que debe-como no puede ser de otra manera- muchas cosas a Italia. Negarlo sería necio, olvidarlo un grave error. 
